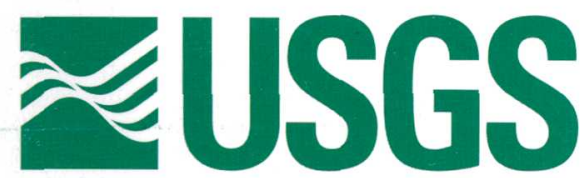

science for a changing world

\title{
Microbiological and Chemical Quality of Ground Water used as a Source of Public Supply in Southern Missouri-Phase I, May 1997-March 1998
}

Water-Resources Investigations Report 00-4038

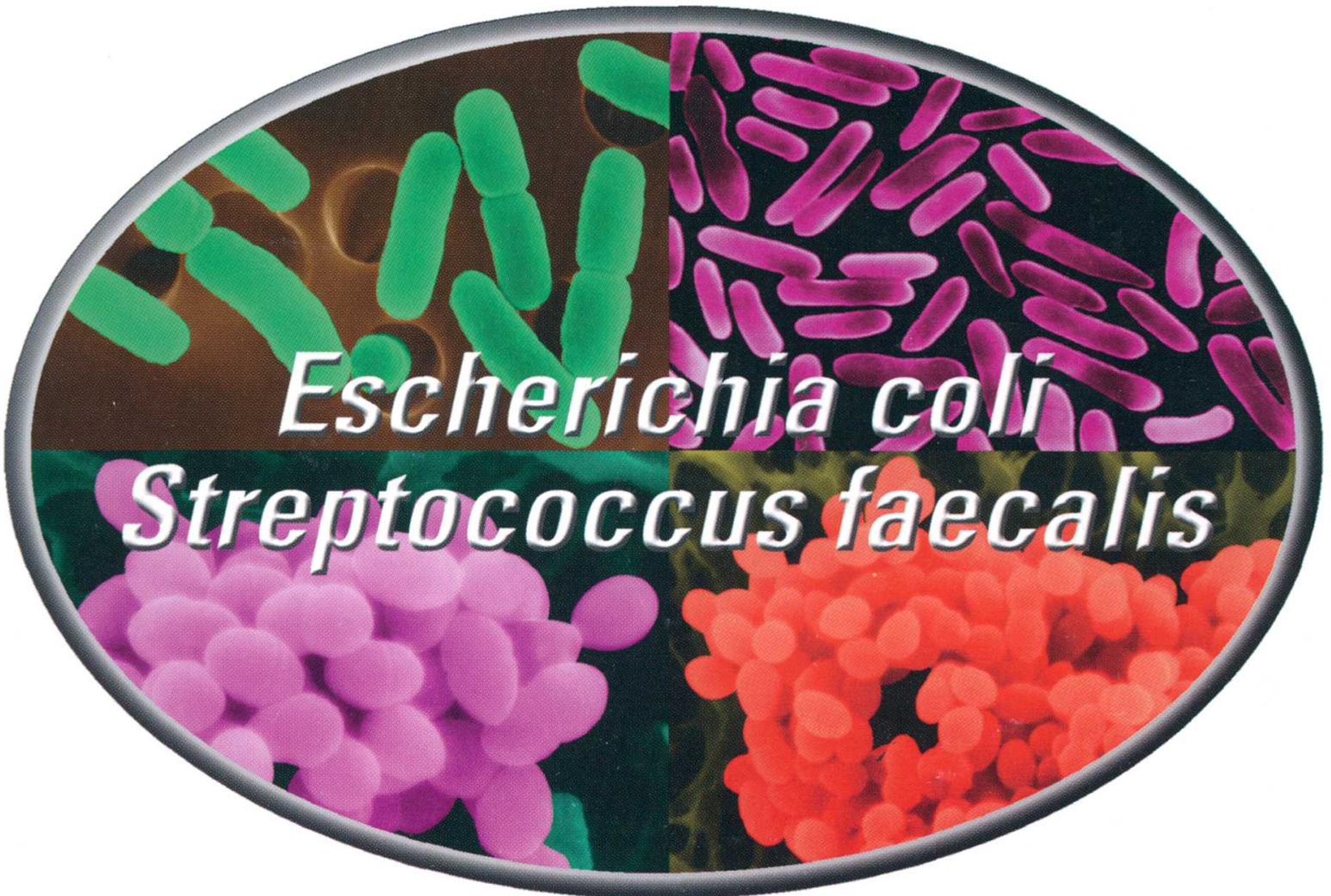

Prepared in cooperation with the

Missouri Department of Natural Resources,

Division of Environmental Quality,

Public Drinking Water Program 
Cover image: Scanning electron micrograph image. Copyright: 1999, Dennis Kunkel, University of Hawaii, http://www.pbrc.hawaii.edu/kunkel. 


\section{Microbiological and Chemical Quality of Ground Water used as a Source of Public Supply in Southern Missouri-Phase I, May 1997-March 1998}

By Jerri V. Davis and Emitt C. Witt, III

Water-Resources Investigations Report 00-4038

In cooperation with the

Missouri Department of Natural Resources,

Division of Environmental Quality,

Public Drinking Water Program 


\title{
U.S. Department of the Interior
}

Bruce Babbitt, Secretary

\section{U.S. Geological Survey}

Charles G. Groat, Director

The use of firm, trade, and brand names in this report is for identification purposes only and does not constitute endorsement by the U.S. Geological Survey.

For addtional information write to:

Copies of this report can be purchased

from:

\section{District Chief}

U.S. Geological Survey

1400 Independence Road

Mail Stop 100

Rolla, MO 65401

\author{
U.S. Geological Survey \\ Branch of Information Services \\ Box 25286 \\ Denver, CO 80225-0286
}




\section{CONTENTS}

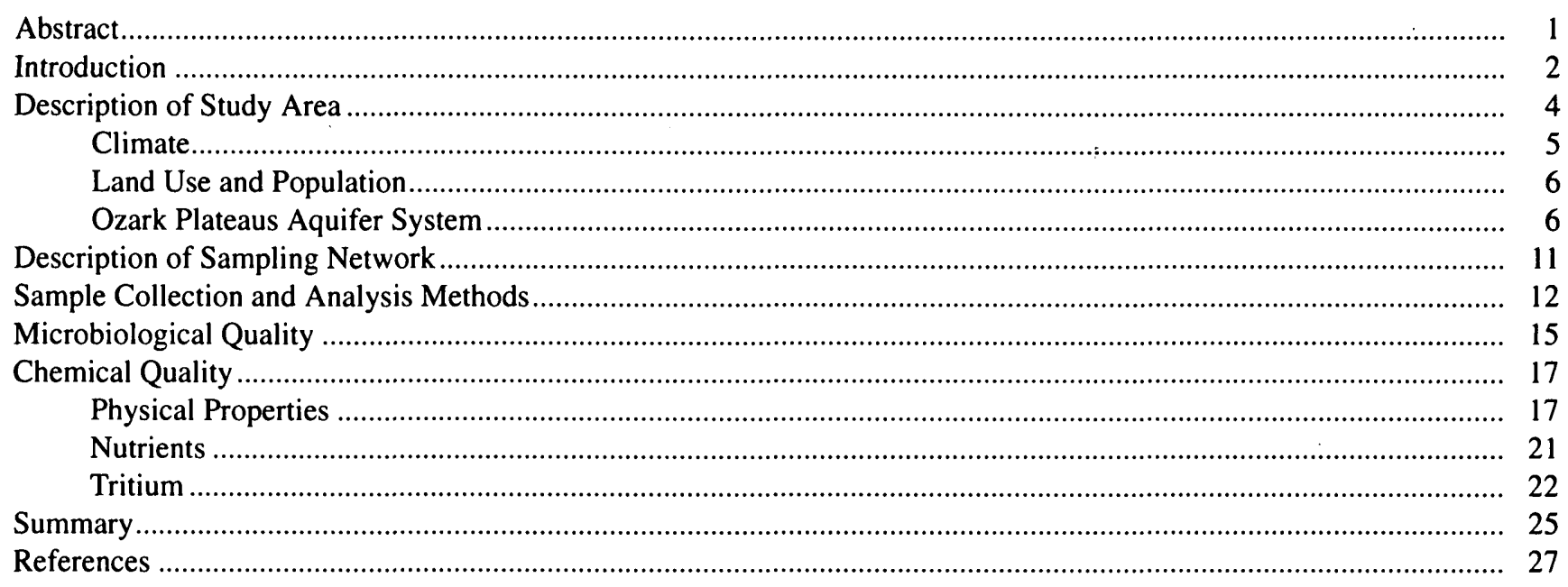

\section{FIGURES}

1.-3. Maps showing:

1. Location of hydrogeologic units and public-water-supply wells in Missouri

2. Monthly precipitation (April 1997 through March 1998) and mean monthly precipitation (1961-90) for selected cities in southern Missouri.

3. Land use in Missouri

4. Photograph showing forest land use in the Ozark Plateaus.

5. Photograph showing agricultural land use in the Ozark Plateaus

6. Map showing county population estimates for 1997 and percentage increase in population by county, 1990-97

7. Photograph showing cave opening upstream of River Bluff Cave, St. Louis County, Missouri

8. Schematic section of regional geohydrologic units in and adjacent to the Ozark Plateaus aquifer system.

9. Map showing aquifer classification, karst areas, and location of public-water-supply wells sampled

10. Photograph showing virus sampling equipment and public-water-supply well......

11. Map showing results of enteric virus, coliphage, and indicator bacteria analyses for samples collected at selected public-water-supply wells.

12. Boxplots showing statistical distribution of specific conductance and dissolved-oxygen concentrations of selected public-water-supply wells grouped by aquifer type

13. Map showing specific conductance values at selected public-water-supply wells.

14. Map showing dissolved-oxygen concentrations at selected public-water-supply wells

15. Boxplots showing statistical distribution of total nitrate plus nitrite concentrations of selected publicwater-supply wells grouped by aquifer type...

16. Map showing total nitrite plus nitrate concentrations at selected public-water-supply wells

17. Boxplots showing weighted averages of tritium concentrations in precipitation in the St. Louis area from 1953 to 1992 adjusted for decay to 1997 values

18. Map showing pre- and post-1953 water from selected public-water-supply wells 


\section{TABLES}

1. Characteristics of public-water-supply wells sampled ......................................................................................

2. Physical property, microbiological, nutrient, organic carbon, and tritium data for selected public-water-supply wells

Analytical methods and method detection levels for water samples

4. Statistical summary of physical property, nutrient, and tritium data for samples collected at selected public-water-supply wells 


\title{
Microbiological and Chemical Quality of Ground Water used as a Source of Public Supply in Southern Missouri-Phase I, May 1997-March 1998
}

\author{
by Jerri V. Davis and Émitt C. Witt, III
}

\section{Abstract}

The U.S. Geological Survey, in cooperation with the Missouri Department of Natural Resources, Division of Environmental Quality, Public Drinking Water Program, has conducted a two-phase study to characterize the microbiological and chemical quality of ground water in the Ozark Plateaus aquifer system, which underlies the Ozark Plateaus region. During Phase I of the study, 109 public-water-supply wells were sampled in water year 1997 and again in water year 1998. Samples from each well were analyzed for the following microbiological species-total human enteric viruses, male-specific and somatic coliphage, and fecal indicator bacteria. In addition, samples were collected and analyzed for physical properties and chemical constituents, such as nutrients, total organic carbon, and tritium, that may serve as indicators of possible surficial sources of contamination of the aquifer.

The microbiological data indicate that microbiological contamination at public-watersupply wells in the Ozark Plateaus aquifer system is not widespread. A relatively small percentage of the wells show contamination by potentially pathogenic viruses or other pathogen indicator organisms. Of the 109 wells sampled during the first round, 94 ( 86 percent) showed no presence of microbiological contamination. Human enteric viruses were present in a sample from 1 of the 109 wells at a concentration of 2.1 most probable number per 100 liters; coliphage were observed in samples from 11 of the 109 wells at concentrations ranging from 38 to 2,600 plaque forming units per 100 liters; and fecal indicator bacteria were observed at small densities in samples from 3 wells. Of the 109 wells sampled during the second round, 98 ( 90 percent) showed no presence of microbiological contamination, coliphage were present in samples from 3 wells at concentrations ranging from 41 to 78 plaque forming units per 100 liters, and fecal indicator bacteria were observed in samples from 8 wells at densities ranging from 15 to 50 colonies per 100 milliliters. Results varied considerably between the first and second rounds of sampling, and no apparent correlation exists between the presence of enteric viruses and coliphage or indicator bacteria.

The enteric virus positive sample and 10 of the 13 coliphage positive samples in the Ozark Plateaus were found in samples from publicwater-supply wells located in the area where the Ozark aquifer is confined by the Ozark confining unit or in the area where the Ozark aquifer is unconfined and where the karst is considered to be nonsignificant. The location of the enteric virus, coliphage, and indicator bacteria positive wells from the first round of sampling generally correlate with the counties that have the most intense agricultural land use or have an estimated 1997 population of greater than $30,000 \mathrm{and} /$ or have experienced an estimated population increase of greater than 10 percent from 1990 to 1997. The eight fecal indicator bacteria positive wells from the second round of sampling are 
located in the area with mature karst features and probably are related to hydrologic conditions at the time of sampling.

An evaluation of the physical property and nutrient data indicated that specific conductance values and dissolved-oxygen and total nitrate plus nitrite concentrations differed significantly among samples from wells located in three defined areas of aquifer vulnerability. The smallest specific conductance values generally occurred along a major ground-water divide that extends from southwestern Missouri to the St. Francois Mountains of southeastern Missouri and increase away from the divide. The smallest dissolved-oxygen and total nitrite plus nitrate concentrations generally occurred in southwestern Missouri where the Ozark aquifer is confined and in the north-central part of the study area where the Ozark aquifer is unconfined and karst features are not extensively developed.

Tritium concentrations of 49 wells sampled in the first round show that 38 wells produce water that is older than 50 years, and 11 wells produce water that is a mixture of pre- and post-1953 water. No relation was seen between tritium concentration and presence of karst geohydrologic features or microbiological contamination.

\section{INTRODUCTION}

Missouri is widely dependent on ground water as a source of drinking water for its public-water systems, businesses, farms, and rural homes. Ninety-five percent of the public-water systems in the State depend on ground water, and about 3,700 publicwater-supply (PWS) wells are located within the State (fig. 1). Historically, water provided from the deep bedrock aquifers in the Ozark Plateaus (most of the southern one-half of Missouri) generally has been free of total and fecal coliform bacterial contamination. Years of bacteriological monitoring have confirmed that water drawn from properly constructed wells in this area is generally free of total and fecal coliform bacteria (Kenneth Duzan, Missouri Department of Natural Resources, written commun., 1997).

In 1986, Congress amended the Safe Drinking Water Act (SDWA) requiring the U.S. Environmental Protection Agency (USEPA) to promulgate disinfec- tion requirements for all public-water supplies. The USEPA promulgated the Surface Water Treatment Rule (SWTR) in June 1989 to establish disinfection requirements for all public-water supplies that use surface water or ground water under the direct influence of surface water. In 1996, Congress again amended the SDWA requiring the USEPA to develop a Ground Water Rule (GWR) that specifies the appropriate use of disinfection for public-water supplies that use ground water not under the direct influence of surface water. A key aspect of the 1996 amendments is the provision that disinfection be required only as necessary. The GWR also addresses other components of ground-water systems to assure public health protection. The Missouri Department of Natural Resources, Division of Environmental Quality, Public Drinking Water Program (PDWP), is responsible for regulating contaminants in public-water supplies in Missouri. The forthcoming GWR (U.S. Environmental Protection Agency, 2000) would be enacted at the State level and enforced by the PDWP (Kenneth Duzan, Missouri Department of Natural Resources, written commun., 1999).

Reporting waterborne disease outbreaks to the Federal government is voluntary, and it is generally acknowledged that more waterborne outbreaks occur than are recognized and reported to the Department of Health and Human Services, Centers for Disease Control (CDC), and the USEPA (Craun, 1986). From 1971 to 1994,650 waterborne outbreaks in systems using surface and ground-water sources were reported, resulting in an estimated 564,750 cases of illness (Craun and Calderon, 1996). This total includes 403,000 cases from a single surface-water outbreak of Cryptosporidium in Milwaukee, Wisconsin, in 1993 (MacKenzie and others, 1994). Excluding that single outbreak, 58 percent of all waterborne outbreaks and 52 percent of the associated illness were associated with water systems using a ground-water source. About 10 percent of the documented outbreaks of waterborne disease in ground-water systems could be attributed to illness of probable viral etiology (Craun and Calderon, 1996). Large ground-water outbreaks are rare because most ground-water systems are small. One large outbreak occurred in 1980 in Georgetown, Texas, where 7,900 people became ill after the consumption of untreated well water contaminated with Coxsackievirus and hepatitis A virus (Hejkal and others, 1982). The well was located in a karst geohydrologic setting. 


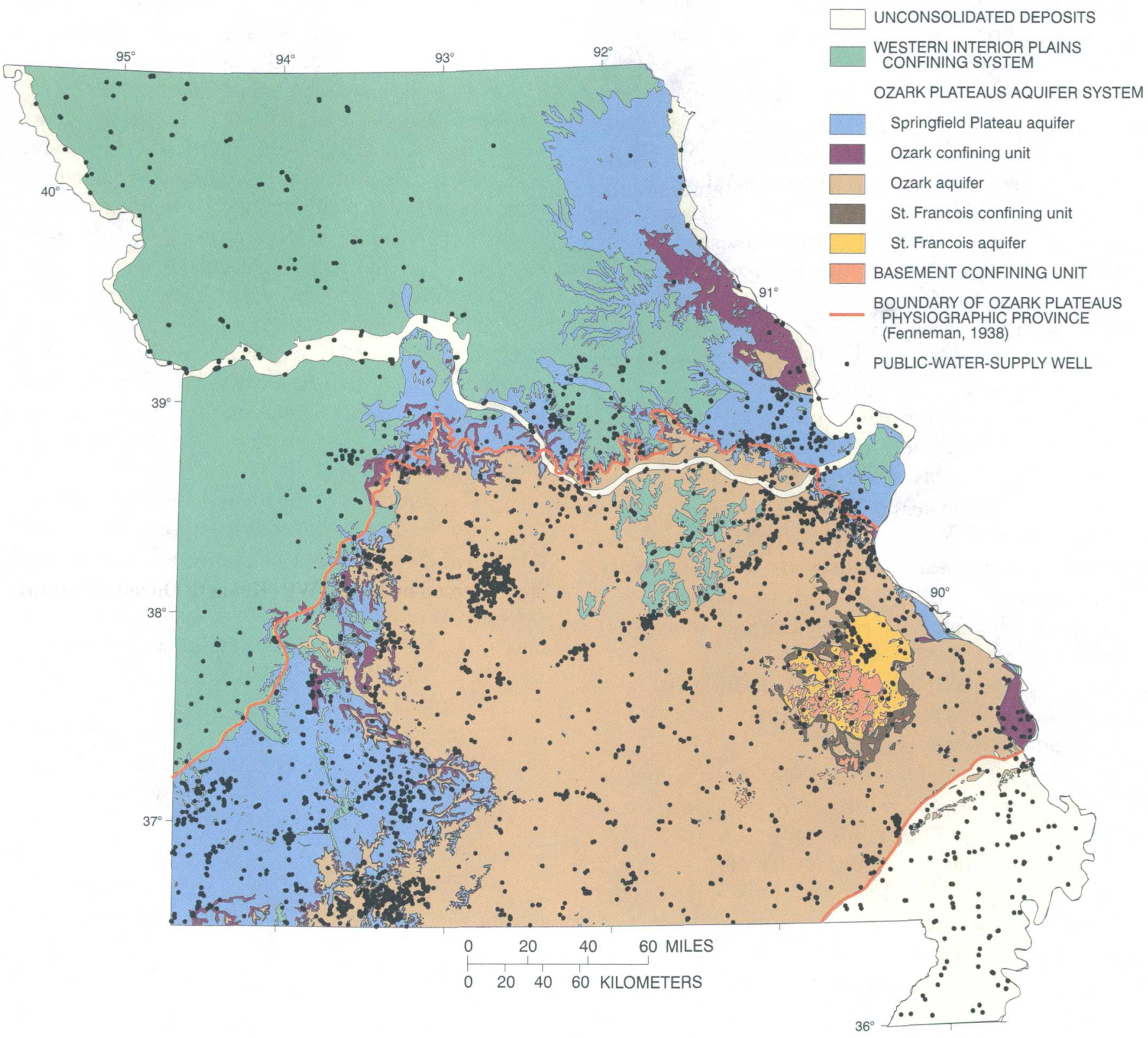

Figure 1. Location of hydrogeologic units (modified from Imes and Emmett, 1994) and public-water-supply wells (Missouri Department of Natural Resources, Public Drinking Water Program) in Missouri.

Many different types of potentially harmful enteric viruses and other pathogens are excreted in livestock and human feces, and they are widely distributed in type and number in domestic sewage, agricultural wastes, and septic drainage systems (Gerba, 1988). The health significance of enteric viruses in humans ranges from poliomyelitis (polio), hepatitis, and gastroenteritis to innocuous infections. Fecal contamination of ground water can occur from failed septic systems, leaking sewer lines, and from land discharge by passage through soils and fissures. This contamination might reach the zone of contribution to a drinking water well; might enter the well along the casing or through cracks in the sanitary seal if the well is not properly constructed, protected, or maintained; or might enter the distribution system when cross-connection controls fail or when negative pressure in a leaking pipe allows contaminant infiltration. In community water systems using ground water, contaminated source water (either untreated or inadequately 
treated) was the cause of 68 percent of the waterborne disease outbreaks, and distribution system deficiencies were associated with 29 percent of the outbreaks (U.S. Environmental Protection Agency, 2000).

Several waterborne disease outbreaks associated with ground-water sources have been documented in Missouri. During May 7-26, 1978, several outbreaks of gastroenteritis (at least 759 documented cases) were reported in high school teams that had visited West Plains, Missouri (Craun, 1984). An investigation revealed that the municipal sewage lagoon had leaked approximately 18 million gallons of its contents into the ground. The karst geohydrologic setting of the area together with numerous untreated private wells appeared to be responsible for the size of the outbreak. Stool cultures were negative for bacterial pathogens, suggesting a possible viral etiology.

Twenty-eight cases of hepatitis A occurred in 1992 among the members and visitors to a church and school located in Racine, Missouri (M.F. Skala, Missouri Department of Health, written commun., 1992). Analysis of samples of the untreated well water from the church and school showed extensive contamination with fecal coliform bacteria, indicating that the well water at the church and school was the most likely source for the outbreak.

In 1989, 4 deaths and 243 illnesses occurred in Cabool, Missouri, as a result of distribution system contamination by Escherichia coli (E. coli) 0157:H7 (Geldreich and others, 1992; and Swerdlow and others, 1992). Untreated ground-water quality was not a factor, but some disturbances in the distribution system may have allowed contaminants to enter the water supply.

In 1993, 7 deaths and 650 illnesses occurred in Gideon, Missouri, as a result of distribution system contamination by Salmonella typhimurium (Angulo and others, 1997). A field investigation conducted by the MDNR, the USEPA, and the CDC concluded that the source of the outbreak was bird fecal contamination in a municipal water tank.

Much is known about total and fecal coliform bacterial contamination, but little is known about viral contamination and its relation to the bacterial and chemical characteristics of ground water. The study of viruses and their relation to other parameters has not been addressed adequately in the past because of the technical restraints of monitoring and analysis, as well as the high cost of these techniques. The U.S. Geological Survey (USGS), in cooperation with the PDWP, has conducted a two-phase study to characterize the microbiological and chemical quality of ground water in the Ozark Plateaus aquifer system, which underlies the Ozark Plateaus region. During Phase I of the study, 109 PWS wells were sampled in water year 1997 (October 1996-September 1997) and again in water year 1998 (October 1997-September 1998).

This study evaluates the quality of ground water used as a source of public supply, not the quality of the treated water. Results of this study will provide State regulatory agencies with data needed to understand potential threats to PWS wells, to make informed decisions on treatment of potable ground-water supplies in the Ozark Plateaus. The results also will provide useful and timely input to the USEPA in the formulation of ground-water disinfection rules for this type of carbonate aquifer system that are protective of the health of consumers.

The objectives of the Phase I study were to (1) determine the densities of enteric viruses and indicator bacteria in ground water from water-bearing units in the Ozark Plateaus aquifer system; (2) determine if the presence of enteric viruses is associated with the presence of indicator bacteria; (3) determine which waterbearing units are most susceptible to viral and bacterial contamination; (4) determine the effect of land use on the presence of viral and bacterial contamination; (5) determine if the presence of enteric viruses and/or indicator bacteria is associated with water chemistry; and (6) identify possible indicators of microbiological contamination.

The purpose of this report is to describe Phase I of the cooperative study. This report includes (1) a description of the study area, including climate, land use and population, and geohydrology; (2) a description of the sampling network; (3) a description of the sample collection and analysis methods; and (4) an assessment of the microbiological and chemical quality of the Ozark Plateaus aquifer system using statistical and graphical methods.

\section{DESCRIPTION OF STUDY AREA}

The study area includes the Ozark Plateaus physiographic province (hereafter referred to as Ozark Plateaus), which covers most of southern Missouri (the area south of the Missouri River) with the exception of the extreme southeast and west-central parts (fig. 1). The following sections briefly describe the climate, land use and population, and geohydrology of the study area. 


\section{Climate}

The Ozark Plateaus has a temperate climate with average annual precipitation increasing from about 38 inches per year (in/yr) in the northern part of the study area, near the Missouri River, to about $48 \mathrm{in} / \mathrm{yr}$ in the southeastern part of Missouri (Dugan and Peckenpaugh, 1985). Average monthly precipitation generally is greatest in the spring [April through June; about 3 to 5 inches per month (in/mo)] and least in the late fall and winter (November through February; about 1 to 3 in/mo). Mean annual air temperature ranges from about 56 degrees Fahrenheit $\left({ }^{\circ} \mathrm{F}\right)$ in the northeastern part of the study area near the Missouri River to about $60^{\circ} \mathrm{F}$ in the southwestern part of the study area (Dugan and Peckenpaugh, 1985). Monthly precipitation during the sampling period (April 1997 through March 1998) and mean monthly precipitation for selected cities in southern Missouri is shown in figure 2.

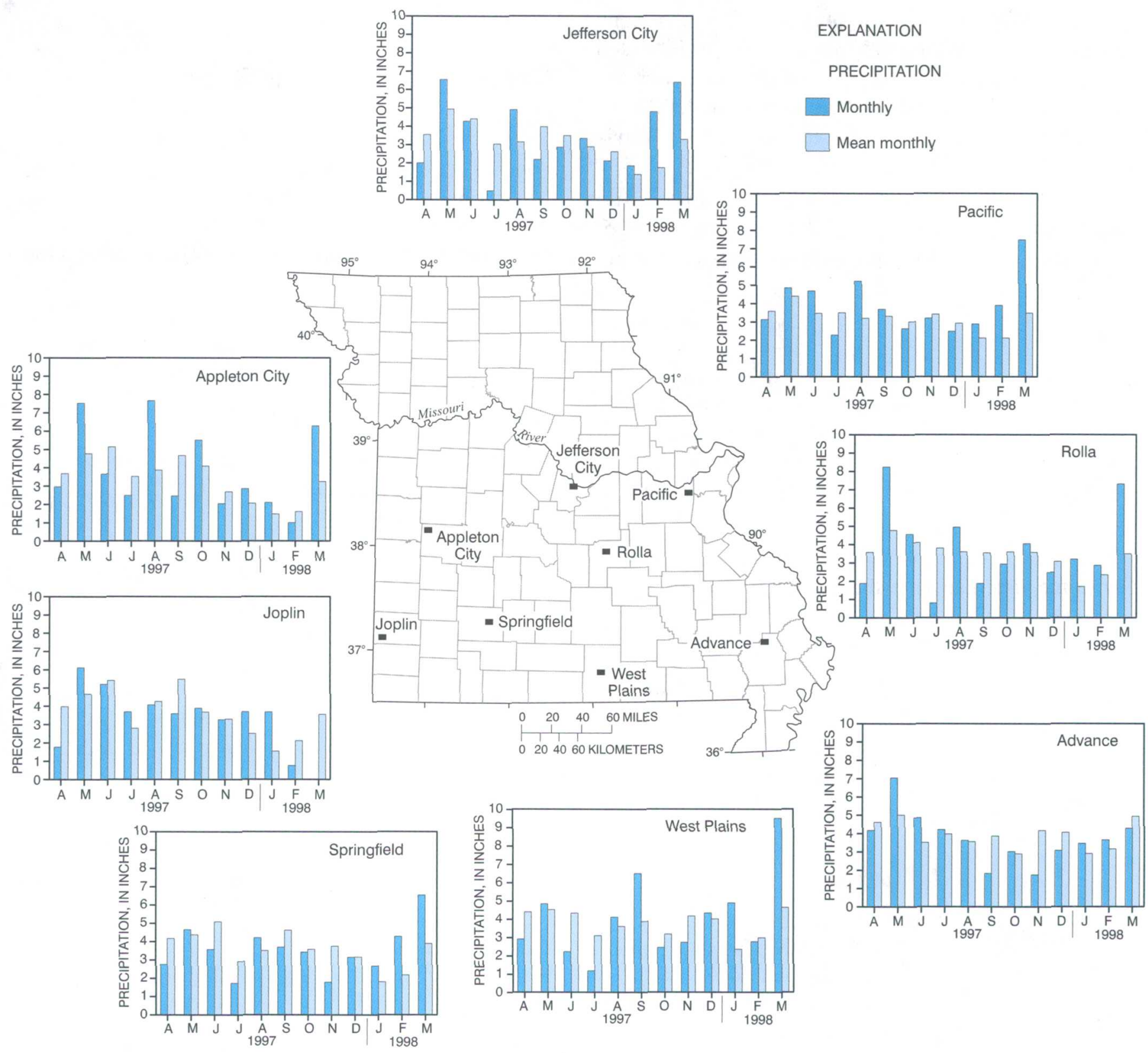

Figure 2. Monthly precipitation (April 1997 through March 1998) and mean monthly precipitation (1961-90) for selected cities in southern Missouri. 


\section{Land Use and Population}

Land use in the Ozark Plateaus primarily is forest and agriculture, including pasture, cropland, and confined animal feeding operations (CAFOs) (figs. 3, 4, and 5; U.S. Geological Survey, 1990). Secondgrowth, deciduous forest mixed with evergreen forest is predominant in the eastern two-thirds of the Ozark Plateaus, and agricultural land use is predominant in the southwestern part of the Ozark Plateaus. Agricultural land use in the study area primarily consists of raising livestock, including beef and dairy cattle, poultry, and swine. Numerous confined poultry operations are present in southwestern Missouri. Waste generated by cattle, poultry, and swine operations is a major source of nutrients and fecal bacteria. Much of the manure is applied to local pastures as fertilizer (Davis and others, 1995; Davis and Bell, 1998).

The population in the Ozark Plateaus was estimated at 1.73 million in 1997 (University of Missouri, 1998). The 1997 county population estimates and the estimated percentage increase in county population from 1990 to 1997 are shown in figure 6(University of Missouri, 1998). Springfield is the largest city with an estimated 1996 population of about 143,000. Cape Girardeau, Jefferson City, and Joplin are the only other cities with populations exceeding 30,000. Recreational activities in the Lake of the Ozarks and the Table Rock Lake-Lake Taneycomo areas have attracted many tourists and year-round residents. The population of the Table Rock Lake-Lake Taneycomo area is estimated to have increased by greater than 30 percent from 1990 to 1997.

\section{Ozark Plateaus Aquifer System}

The Ozark Plateaus aquifer system generally consists of carbonate (dolostone or limestone) rocks of Mississippian through Cambrian age, with numerous karst features, such as caves (fig. 7), springs, sinkholes, solution-enlarged fractures, and losing streams.

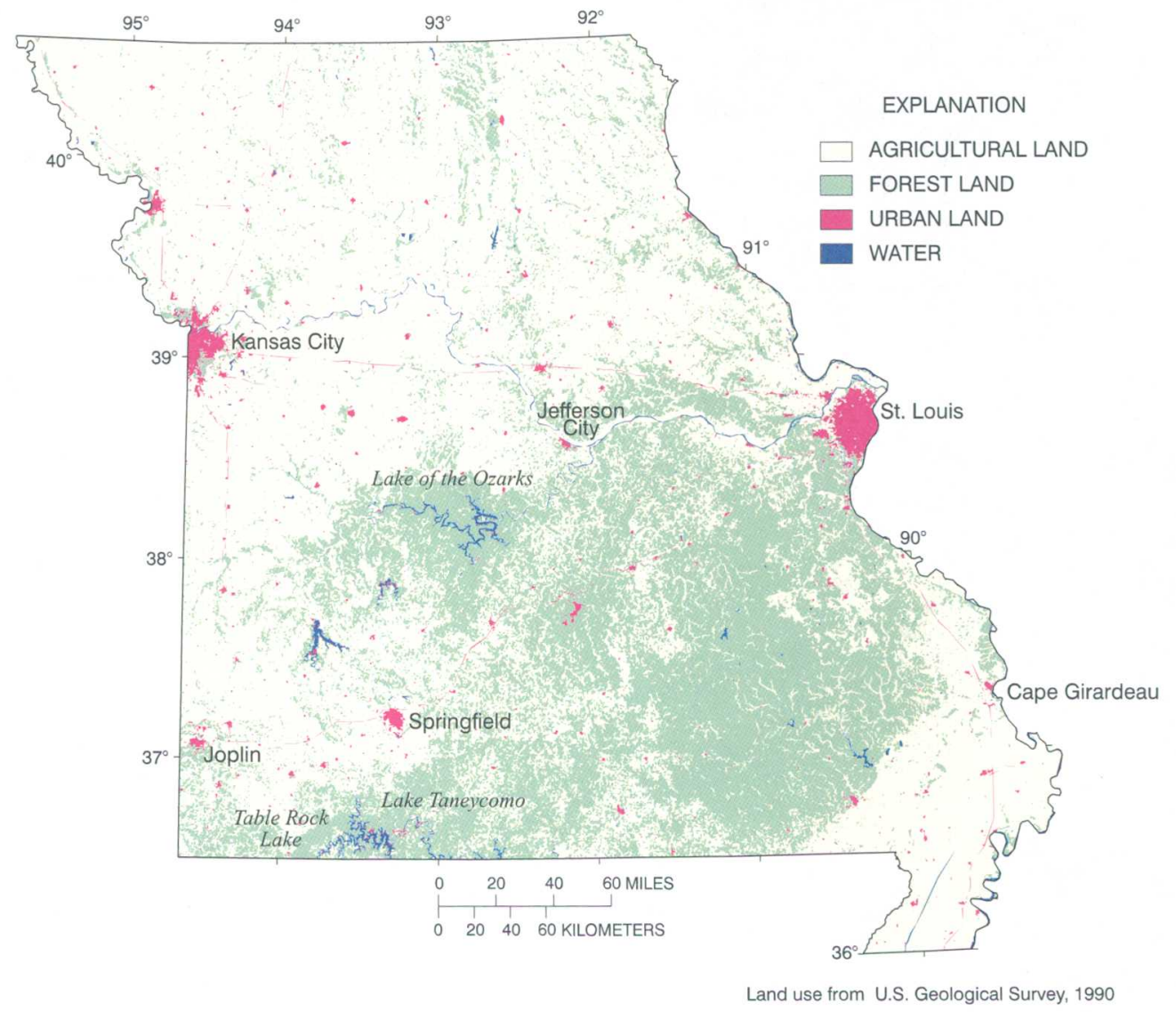

Figure 3. Land use in Missouri. 


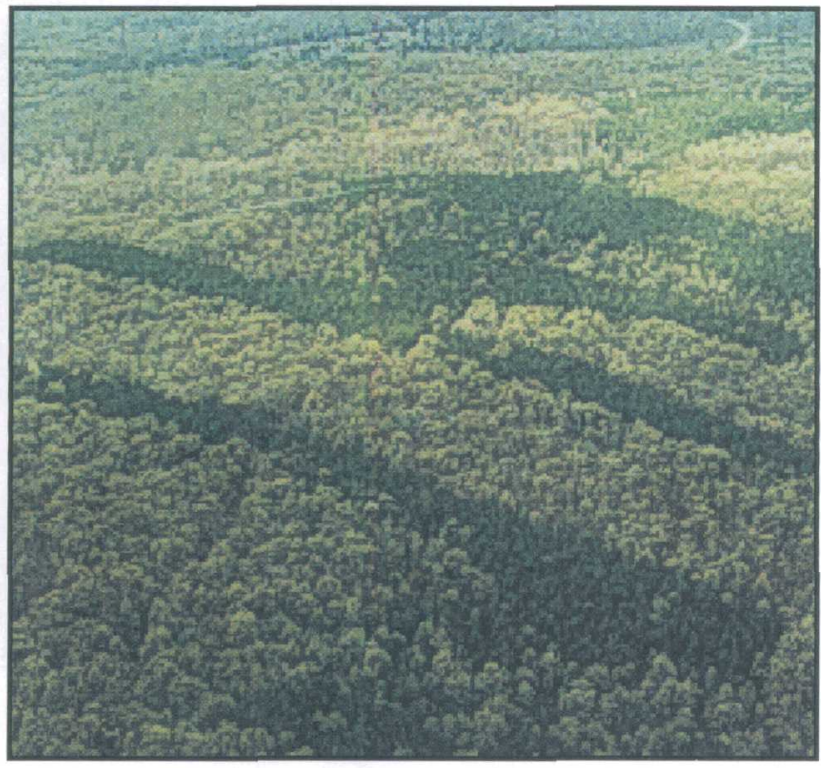

Figure 4. Forest land use in the Ozark Plateaus. Photo courtesy of S.R. Femmer, U.S. Geological Survey.

Five regional geohydrologic units consisting of sequences of stratigraphic units comprise the Ozark Plateaus aquifer system and are defined as aquifers or confining units based on permeability and well yield. Generally, aquifers are permeable and are considered capable of providing a water supply, whereas confining units are weakly permeable or impermeable and generally are not capable of providing a water supply. These regional geohydrologic units are, from top to bottom: the Springfield Plateau aquifer, the Ozark confining unit, the Ozark aquifer, the St. Francois confining unit, and the St. Francois aquifer (figs. 1 and 8; Imes and Emmett, 1994).

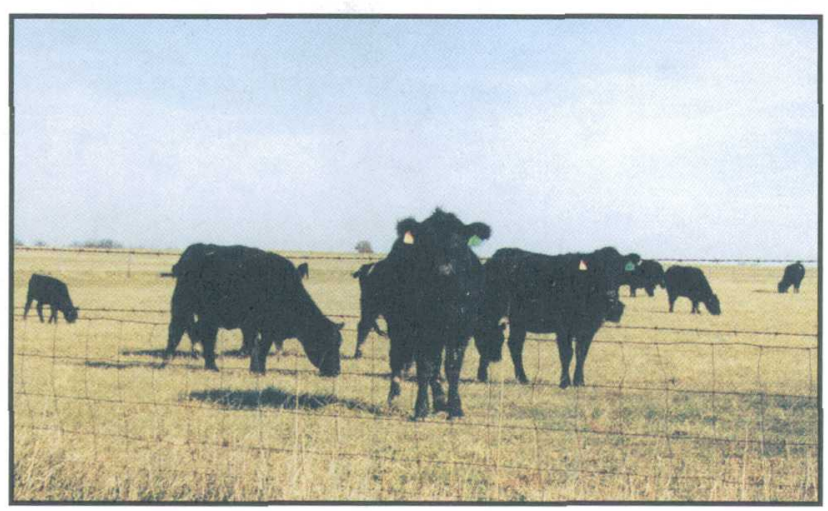

Figure 5. Agricultural land use in the Ozark Plateaus. Photo courtesy of B.J. Smith, U.S. Geological Survey.
The aquifers of the Ozark Plateaus aquifer system can be described as being confined or unconfined. An aquifer is confined where it is overlain by a confining unit and is unconfined where it is not overlain by a confining unit. The Springfield Plateau aquifer is unconfined except where it is overlain by the Western Interior Plains confining system in the northwestern part of the study area. The Ozark aquifer crops out throughout a large part of the Ozark Plateaus and is unconfined in these areas. It is confined where it extends beneath the Ozark confining unit in the western and northwestern parts and to a lesser extent in the northeastern part of the study area, and where it is locally overlain by the Western Interior Plains confining system in the north central part of the study area (Imes, 1990). Locally in the northwestern part of the study area, the Springfield Plateau aquifer directly overlies the Ozark aquifer (the Ozark confining unit is absent), and the Ozark aquifer is unconfined. The St. Francois aquifer is unconfined in its outcrop area surrounding the St. Francois Mountains in southeastern Missouri and is confined outside this area where it underlies the St. Francois confining unit.

The most important aquifer of the Ozark Plateaus aquifer system for public supplies is the Ozark aquifer. The Ozark aquifer is used as a source of public-water supply, both where it is unconfined and where it is confined (figs. 1 and 8). The St. Francois aquifer is less important as a public-water supply. The St. Francois aquifer is used as a source of public-water supply, both where it is unconfined in its outcrop area, and near its outcrop area where it is confined and the overlying Ozark aquifer is thin or absent. The Springfield Plateau aquifer is not used as a source of publicwater supply where it is unconfined.

Approximately 75 percent of the precipitation that falls in the Ozark Plateaus is removed as evapotranspiration or overland flow to streams (Imes and Emmett, 1994). The remainder (approximately 25 percent) moves downward to the water table and recharges the ground-water system. Some ground water flows to nearby local discharge areas (streams and springs), while a smaller portion of the ground water moves deeper and becomes part of regional flow to more distant discharge areas. Regional groundwater flow can be within an aquifer but can also be from one aquifer to another, such as from the Springfield Plateau aquifer to the Ozark aquifer. In that case, ground water flows through the Ozark confining unit (fig. 8). 


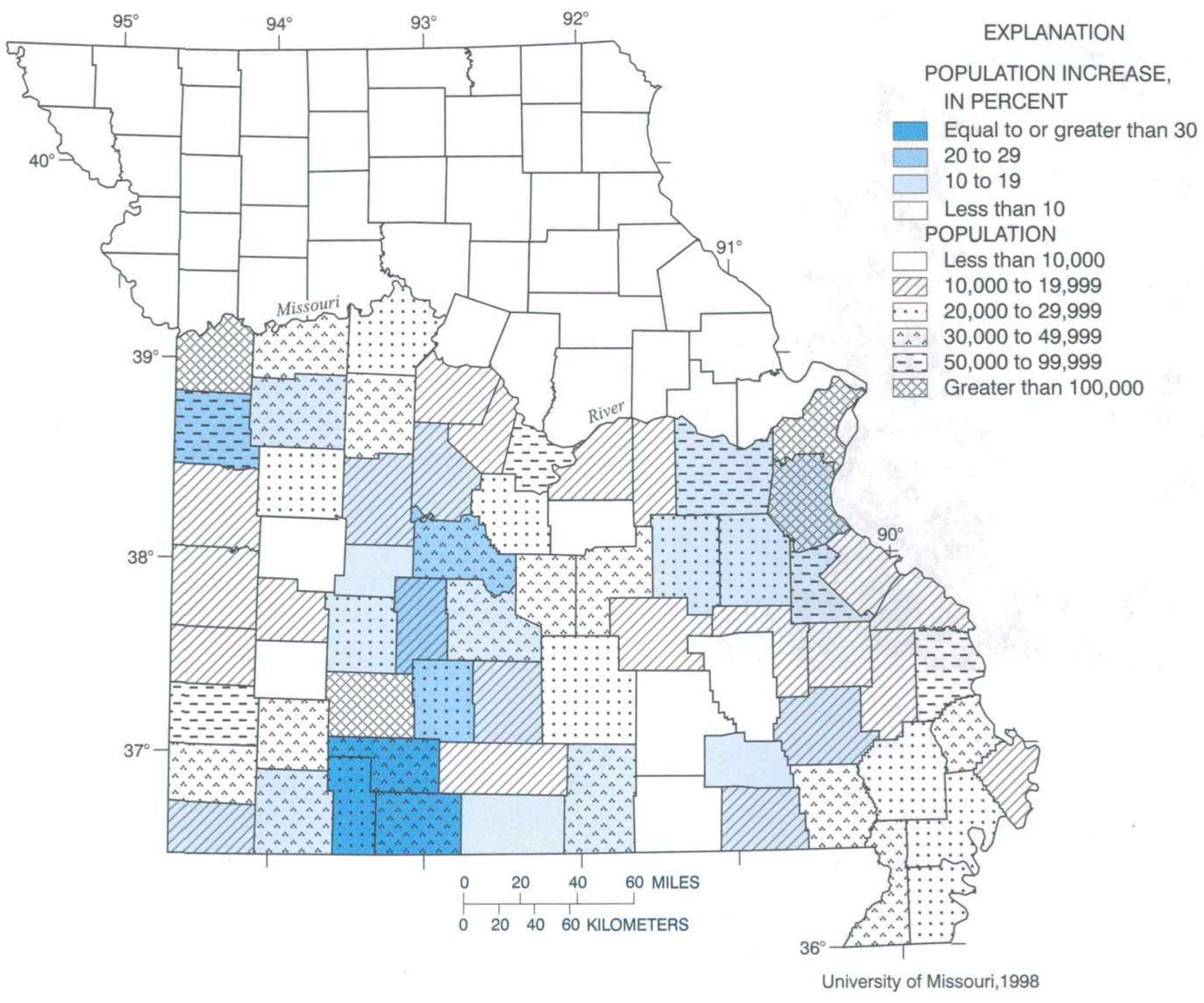

Figure 6. County population estimates for 1997 and percentage increase in population by county, 1990-97.

Ground-water recharge and patterns of groundwater flow are affected by karst features. Groundwater recharge is rapid at sinkholes and along losing stream reaches, and underground solution channels rapidly transport ground water to springs. Surface water may move into the subsurface in one stream basin and discharge to a spring in another basin, in some cases covering a distance of many miles. Harvey (1980) mapped areas with a sinkhole density greater than 10 per 100 square miles and areas with a sinkhole density of 1 to 10 per 100 square miles. Imes and Emmett (1994) named these primary karst areas and secondary karst areas, respectively (fig. 9).

Because surface- and ground-water exchange is relatively free where karst features are well developed, karst aquifers are susceptible to contamination from surface or near-surface sources. Viruses and bacteria can enter and move rapidly through an aquifer where karst features are present. Other factors that also may affect the number and types of microbiologic organisms in an aquifer include the presence of an overlying confining unit, leakage of contaminants through a confining unit due to pumpage or poorly cased wells, the depth of the water table, and land-use practices.

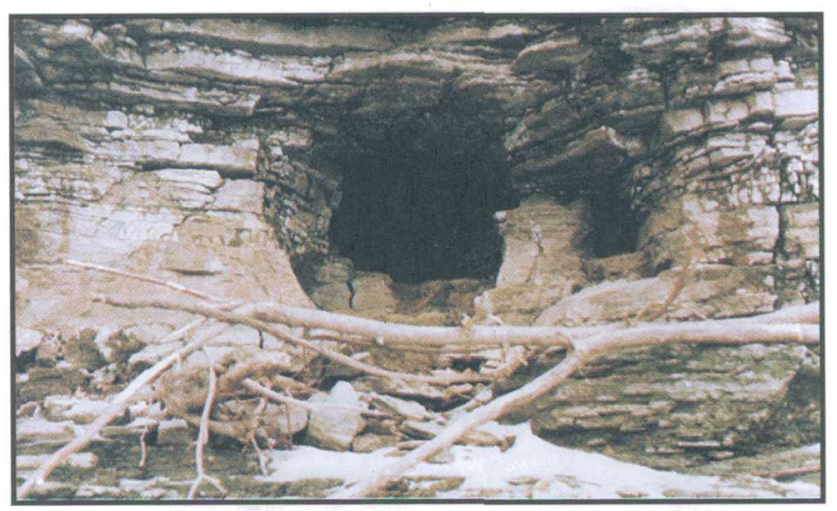

Figure 7. Cave opening upstream of River Bluff Cave, St. Louis County, Missouri. Photo courtesy of J.E. Vandike, Missouri Department of Natural Resources. 


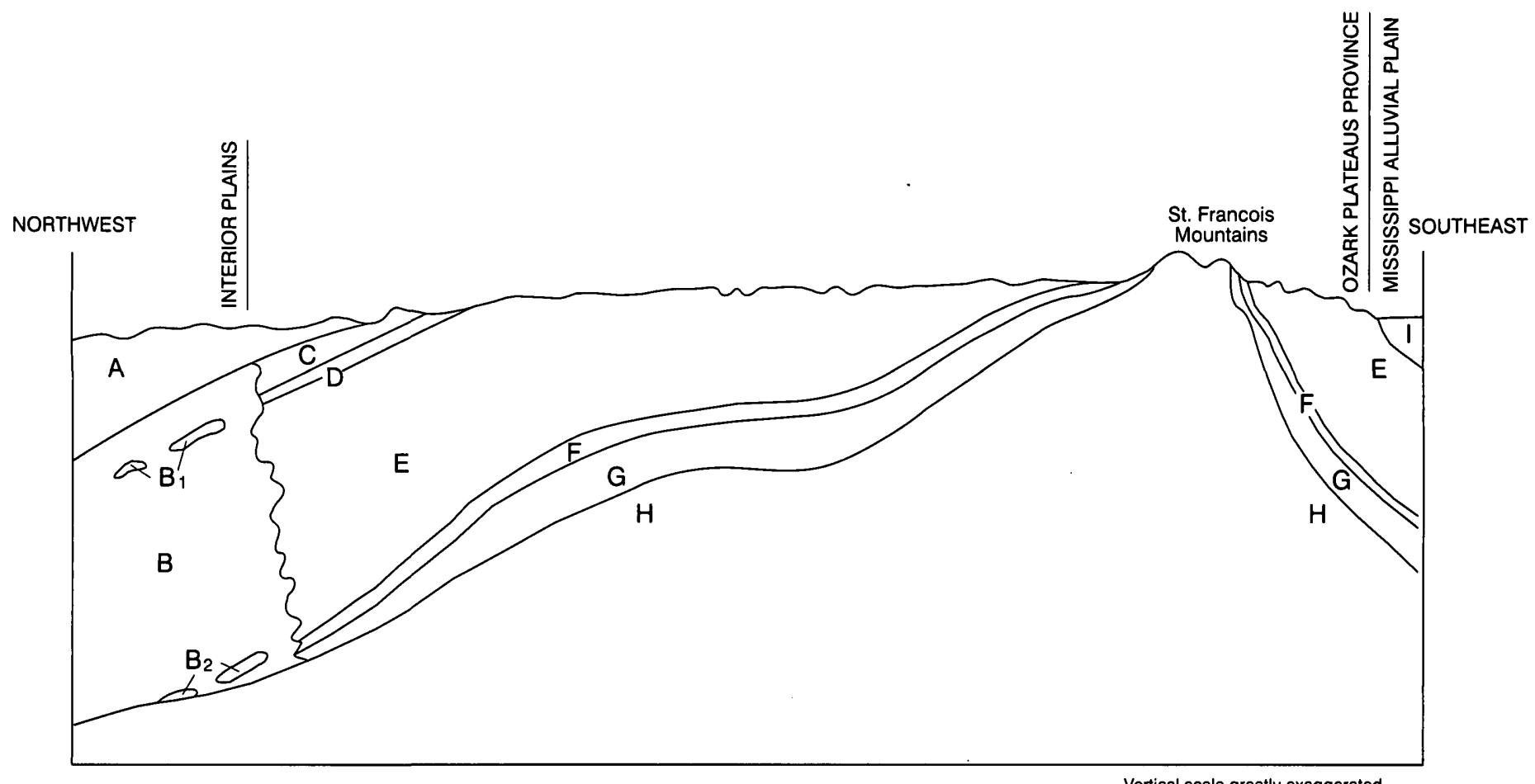

EXPLANATION
A WESTERN INTERIOR PLAINS CONFINING SYSTEM
B WESTERN INTERIOR PLAINS AQUIFER SYSTEM
$B_{1}$ STRATIGRAPHICALLY EQUIVALENT TO OZARK CONFINING UNIT
$B_{2}$ STRATIGRAPHICALLY EQUIVALENT TO ST. FRANCOIS CONFINING UNIT
OZARK PLATEAUS AQUIFER SYSTEM
C Springfield Plateau aquifer
D Ozark confining unit
E Ozark aquifer
F St. Francois confining unit
G St. Francois aquifer
H BASEMENT CONFINING UNIT
I UNCONSOLIDATED DEPOSITS

Figure 8. Schematic section of regional geohydrologic units in and adjacent to the Ozark Plateau aquifer system (modified from Imes and Emmett, 1994).

For this report, an aquifer classification scheme based on geohydrology and the density of karst features was devised (fig. 9). Areas first were delineated according to geohydrology-Ozark aquifer overlain by the Springfield Plateau aquifer and confined by the Ozark confining unit $[\mathrm{C}(\mathrm{OzCU})]$, unconfined Ozark aquifer [U(Oz)], or unconfined St. Francois aquifer [U(SF)]. Secondly, the degree of karst development [karst $(\mathrm{K})$ or nonsignificant karst $(\mathrm{NK})]$ for the unconfined Ozark aquifer or St. Francois aquifer PWS wells was considered. An area in eastern Missouri didn't fit any of these categories and was designated as $\mathrm{O}$ for "Other". This part of the Ozark Plateaus is underlain by Mississippian-aged consolidated rocks that are stratigraphically equivalent, but hydrologically unrelated, to the Springfield Plateau aquifer (Imes and Emmett, 1994). The Mississippi Alluvial Plain of southeastern Missouri was designated as Unc for unconsolidated deposits, and an area in western Missouri was designated as $\mathrm{C}(\mathrm{W})$ for Ozark Plateaus aqui- 


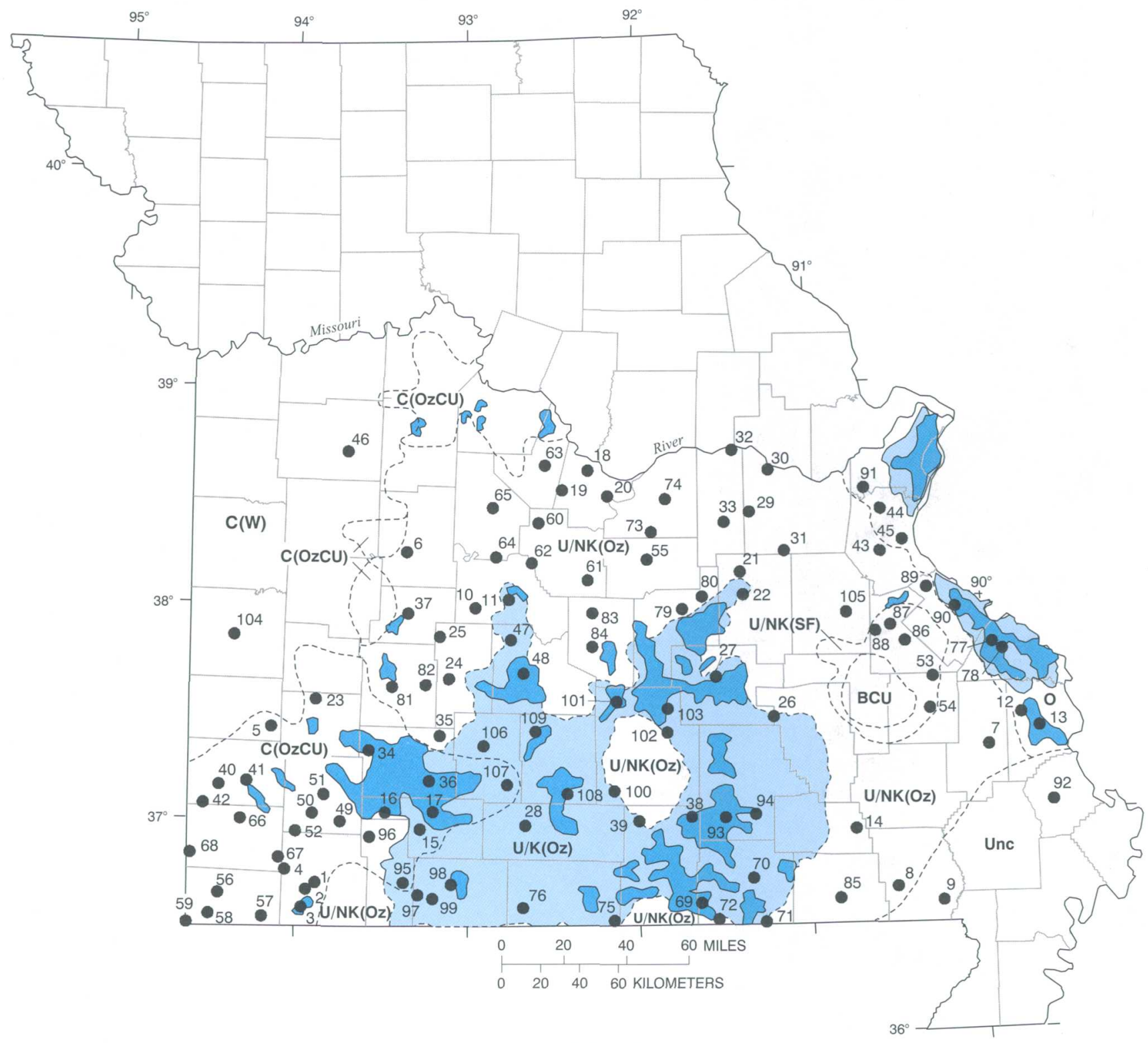

EXPLANATION

PRIMARY KARST AREA

SECONDARY KARST AREA

AQUIFER TYPE

$\mathrm{C}(\mathrm{OzCU})$ Ozark aquifer overlain by Springfield Plateau aquifer and confined by Ozark confining unit

U/NK(Oz) Unconfined Ozark aquifer; nonsignificant karst features

U/NK(SF) Unconfined St. Francois aquifer; nonsignificant karst features

BCU Basement confining unit

$\mathrm{U} / \mathrm{K}(\mathrm{Oz}) \quad$ Unconfined Ozark aquifer; primary and secondary karst features

C(W) Ozark aquifer confined by Western Interior Plains confining system

Unc Unconsolidated

o Other

BOUNDARY OF AQUIFER TYPE

8 PUBLIC-WATER-SUPPLY WELL AND NUMBER (table 1)

Figure 9. Aquifer classification, karst areas (Imes and Emmett, 1994), and location of public-watersupply wells sampled. 
fer system confined by Western Interior Plains confining system (table 1, at the back of this report; fig. 9).

The unconfined Ozark aquifer in south-central Missouri [area $\mathrm{U} / \mathrm{K}(\mathrm{Oz})$ ] is considered most vulnerable to viral and bacterial contamination because of the large density of karst features. The unconfined Ozark aquifer in central and eastern Missouri [area $\mathrm{U} / \mathrm{NK}(\mathrm{Oz})]$ is considered somewhat less vulnerable because the density of karst features is smaller. The confined Ozark aquifer in southwestern Missouri [area $\mathrm{C}(\mathrm{OzCU})$ ] is considered to be the least vulnerable because of the presence of the overlying Ozark confining unit (figs. 1 and 8). In this area, however, the overlying Springfield Plateau aquifer is karstic (fig. 9), and leakage of contaminants can occur through the confining unit, including along open boreholes that are known to penetrate the confining unit (Imes, 1989). The unconfined St. Francois aquifer [area U/NK(SF)], although not very karstic, is considered to be vulnerable to contamination because the aquifer is not confined.

According to an aquifer classification system based on vulnerability to contamination (Miller and others, 1987) devised by the Missouri Department of Natural Resources, Division of Geology and Land Survey (MDNR-DGLS), the contamination potential throughout the areas designated in this report as $\mathrm{U} / \mathrm{K}(\mathrm{Oz})$ and $\mathrm{U} / \mathrm{NK}(\mathrm{Oz})$ largely depends on which geologic formation crops out or is near the surface. Pennsylvanian-aged rock and Ordovicianaged Jefferson City Dolomite-Cotter Dolomite and Upper Gasconade Dolomite in area U/NK(Oz) tend to be unfractured, dense, and only moderately permeable, whereas the Ordovician-aged Roubidoux Formation and Lower Gasconade Dolomite that crop out in area $\mathrm{U} / \mathrm{K}(\mathrm{Oz})$ are highly permeable. In the area designated in this report as $\mathrm{C}(\mathrm{OzCU})$, the Springfield Plateau aquifer primarily is Mississippian-aged cherty limestone that exhibits mild to moderate karstification. However, the Ozark confining unit generally restricts the vertical movement of ground water into the Ozark aquifer. The groundwater flow system in the area designated in this report as U/NK(SF) is complex with Cambrian-aged dolomite, siltstone, shales, and sandstone cropping out in the low and intermediate elevations and Precambrian-aged igneous and metamorphic rocks (Basement confining unit) cropping out in the highlands. The Basement confining unit, which is considered the base of the Ozark Plateaus aquifer system, generally has low permeability and downward circulation through it is generally limited. For a complete description of the water-bearing units in the Ozark Plateaus aquifer system, the reader is referred to Imes and Emmett (1994).

\section{DESCRIPTION OF SAMPLING NETWORK}

The USGS and PDWP selected 105 PWS wells (fig. 9) to provide samples of ground water from the confined and unconfined Ozark and St. Francois aquifers. Four additional PWS wells were selected from areas located adjacent to the Ozark Plateaus. Two of the PWS wells are located in the Interior Plains of western Missouri where the Ozark aquifer is confined by the Ozark confining unit, overlain by the Springfield Plateau aquifer, and confined by the Western Interior Plains confining system $[\mathrm{C}(\mathrm{W})]$, and two are located in the Mississippi Alluvial Plain of southeastern Missouri (Unc) (figs. 1 and 9).

Only community wells-municipal, PWS district, subdivision, and mobile home park-constructed in the last 15 years were considered initially (table 1). This study was designed to eliminate type of well construction as a variable for microbiological contamination so that interpretation could be limited to geohydrology and land use. Well-selection criteria were based on availability of well construction and completion records (well and casing depth, size, and type), well operation and maintenance history, current usage, and geology. Finally, an attempt was made to obtain fairly even areal and vertical coverage in the aquifer system and to represent the different land uses in the Ozark Plateaus. Newer wells were selected when possible because their construction history could be best documented, but about one-third of the PWS wells sampled were older than 15 years. In these cases, older wells were selected to improve areal coverage and/or were the primary water sources for the municipality, PWS district, subdivision, or mobile home park. The older wells did not fit the age criterion but did fit other equally important selection criteria.

Excluding the four wells located in areas adjacent to the Ozark Plateaus, the well depths of the selected PWS wells from 292 to $1,840 \mathrm{ft}$ (table 1). The shallowest wells generally were those located where the St. Francois aquifer is unconfined (fig. 1). Casing depths for the 105 wells ranged from 110 to $700 \mathrm{ft}$, and the total open interval ranged from 75 to $1,440 \mathrm{ft}$ 
(table 1). Most of the 105 wells are open to two or more water-bearing formations in the Ozark aquifer, including the Cotter Dolomite, Jefferson City Dolomite, Roubidoux Formation, Gasconade Dolomite, Eminence Dolomite, and Potosi Dolomite. Exceptions include the five wells located where the St. Francois aquifer is unconfined (wells 53, 54, 86, 87, and 88); well 105 that is cased through the Ozark aquifer; wells 22 and 27 that are open to the Potosi Dolomite in the Ozark aquifer and the Derby-Doerun Dolomite in the St. Francois confining unit; and several wells that are open to formations in the St. Francois confining unit and aquifer (table 1; fig. 9). All wells located in southwestern Missouri where the Ozark aquifer is overlain by the Springfield Plateau aquifer and confined by the Ozark confining unit have casing depths sufficient to exclude water from the Ozark confining unit and the Springfield Plateau aquifer.

\section{SAMPLE COLLECTION AND ANALYSIS METHODS}

Each of the 109 PWS wells were sampled twice-once during the wet-weather season in water year 1997 (May through early July) and again during the dry-weather season in water year 1998 (November 1997 through early March 1998). The aquifers are considered most vulnerable to surficial sources of contamination during wet-weather conditions.
The PWS wells were sampled from a tap located at the well head or the tap nearest to the well head before chlorination or other treatment is done. Before sample collection, the sampling point was sprayed with a 0.1 percent chlorine solution. The well was then pumped for a minimum of 15 minutes or until the specific conductance and temperature readings stabilized. Onsite analysis of temperature, specific conductance, $\mathrm{pH}$, dissolved oxygen, and alkalinity were done at each PWS well according to procedures described by Wilde and Radtke (1998). Physical properties, including temperature, specific conductance, and $\mathrm{pH}$, were measured in a 5-gallon bucket with the water continuously running. Dissolved oxygen was measured at the tap with direct-reading vacuum vials, and a 50-milliliter $(\mathrm{mL})$ aliquot was collected at the tap for alkalinity analysis. Samples for indicator bacteria analysis were collected in sterile, $500-\mathrm{mL}$ polyethylene bottles, chilled at 4 degrees Celsius $\left({ }^{\circ} \mathrm{C}\right)$, and analyzed within 6 hours. Samples for chemical analysis were collected in appropriately designated sample containers. Finally, enteric virus and coliphage samples were collected using the virus sampling apparatus shown in figure 10 following the procedures described in the USEPA Information Collection Requirements (ICR) rule for the collection of samples for protozoa and enteric viruses (U.S. Environmental Protection Agency, 1995a). The samples were filtered through a positively charged filter (1-MDS Zetapor Virosorb filter). Viruses have a net negative charge at a $\mathrm{pH}$ of less than eight and will adsorb to the filter. Sample volumes pro-

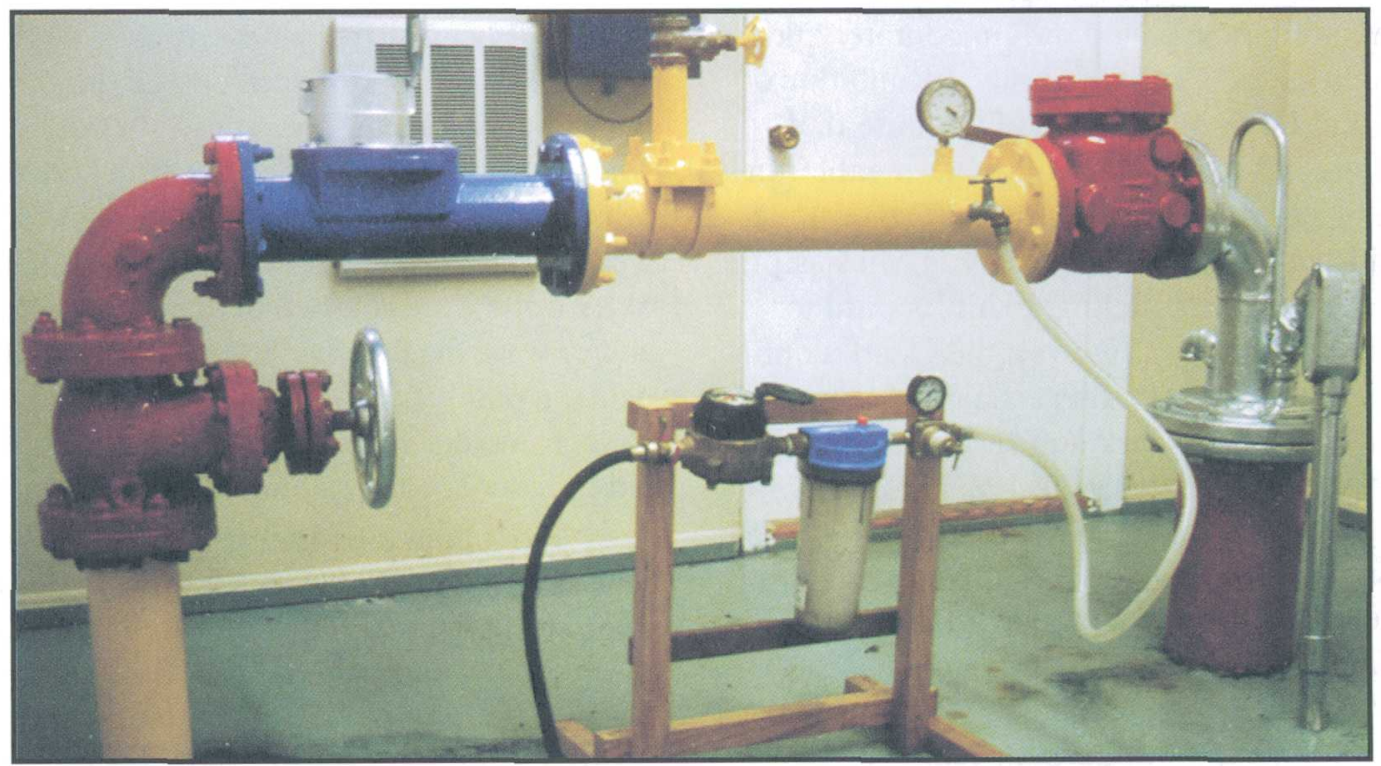

Figure 10. Virus sampling equipment and public-water-supply well. 
cessed for enteric virus and coliphage analysis ranged from 178 to 307 liters and averaged 242 liters (table 2, at the back of this report). All samples represent untreated water from the aquifer.

Samples from each PWS well were analyzed for the following microbiological species-total human enteric viruses, male-specific and somatic coliphage, and fecal indicator bacteria [fecal coliform, $E$. coli, and fecal streptococci]. Coliphage are viruses that attack $E$. coli and are being studied as possible indicators of the presence of human enteric viruses. Coliphage are not human pathogens, but their fate and transport in the subsurface may be similar enough to human enteric viruses to indicate whether human enteric viruses are potentially present. Somatic coliphage enter the cell wall of $E$. coli, and male-specific coliphage enter $E$. coli through tiny hair-like appendages to the cell wall. In addition, a subset of 32 samples from PWS wells considered potentially at risk for contamination from CAFOs were analyzed for bovine and porcine enteric viruses.

Enteric virus and coliphage samples were analyzed by the University of New England in Biddeford, Maine, according to procedures described in the USEPA ICR rule for the analysis of samples for protozoa and enteric viruses (U.S. Environmental Protection Agency, 1995b and 1996). The ICR method, or Total Culturable Virus assay, consists of virus concentration in the field on the 1-MDS filter, elution and reconcentration in the laboratory via the beef extractflocculation method, and growth on monolayers of Buffalo Green monkey kidney cells. Results are given in most probable number per 100 liters of sample (MPN/100 L) which represents cytopathic effect (cell disintegration or changes in cell morphology) in the host cell culture system. The enteric viruses that can be detected by the ICR method include polio, echovirus, and Coxsackie. The samples also were analyzed using an integrated-cell-culture PCR (Polymerase Chain Reaction) method (Reynolds and others, 1996). The advantages of the integrated-cell-culture PCR method is that the analysis takes only about three days versus about six weeks for the ICR method, and some viruses that do not cause cytopathic effect (including Norwalk, hepatitis A virus, and rotavirus) may be detected. However, the PCR method is not a quantitative method, and the test does not distinguish between viruses that are capable of inducing an infection and those that are not.
The coliphage analysis is performed on a subsample of the eluate from the 1-MDS filter prior to the flocculation concentration procedure. The agar overlay technique is used, and the presence of coliphage is indicated by the formation of plaques. Results are given in plaque forming units per 100 liters of sample (PFU/100 L). The host culture used for the somatic coliphage assay is $E$. coli $\mathrm{C}$, and the host culture used for the male-specific assay is $E$. coli $\mathrm{C} 3000$. It should be noted that the extraction procedures in the USEPA ICR method were developed to enhance enteric virus extraction but may be detrimental to the survival of coliphage, thus potentially not giving a true picture of coliphage presence.

Quality control testing also followed guidelines contained in the USEPA ICR (1995b and 1996) and included the weekly analysis of positive and negative control samples. The purpose of a positive control sample is to assure that the laboratory can recover virus using the ICR procedure. The purpose of a negative control sample is to check for contamination of equipment and reagents.

Frozen sample concentrates from all 109 PWS wells sampled were archived at the University of New England. Thirty two of the archived samples were sent to the University of Minnesota in St. Paul, Minnesota, to be analyzed for bovine and porcine enteric viruses using a cell culture method followed by negative contrast electron microscopy and immunofluorescence (Dr. Sagar Goyal, University of Minnesota, written commun., 1999).

Indicator bacteria samples were collected and analyzed by the USGS according to procedures described in Myers and Wilde (1997). Analysis of each type of bacteria was done using a $100-\mathrm{mL}$ aliquot of sample. Reagent blanks were run with each set of samples (a set consisting of three plates, one each for fecal coliform, E. coli, and fecal streptococci bacteria) to check for contamination of equipment and reagents.

In addition to the above microbiological species, samples were collected and analyzed for chemical constituents, such as nutrients, total organic carbon, and tritium, that may serve as indicators of possible surficial sources of contamination of the aquifer. Samples for the analysis of tritium were collected only during the first round of sampling. All chemical analyses were done by USGS laboratories in Arvada, Colorado, or Ocala, Florida, according to procedures described in Fishman and Friedman (1989), Fishman (1993), and Thatcher and others (1977) (table 3). 


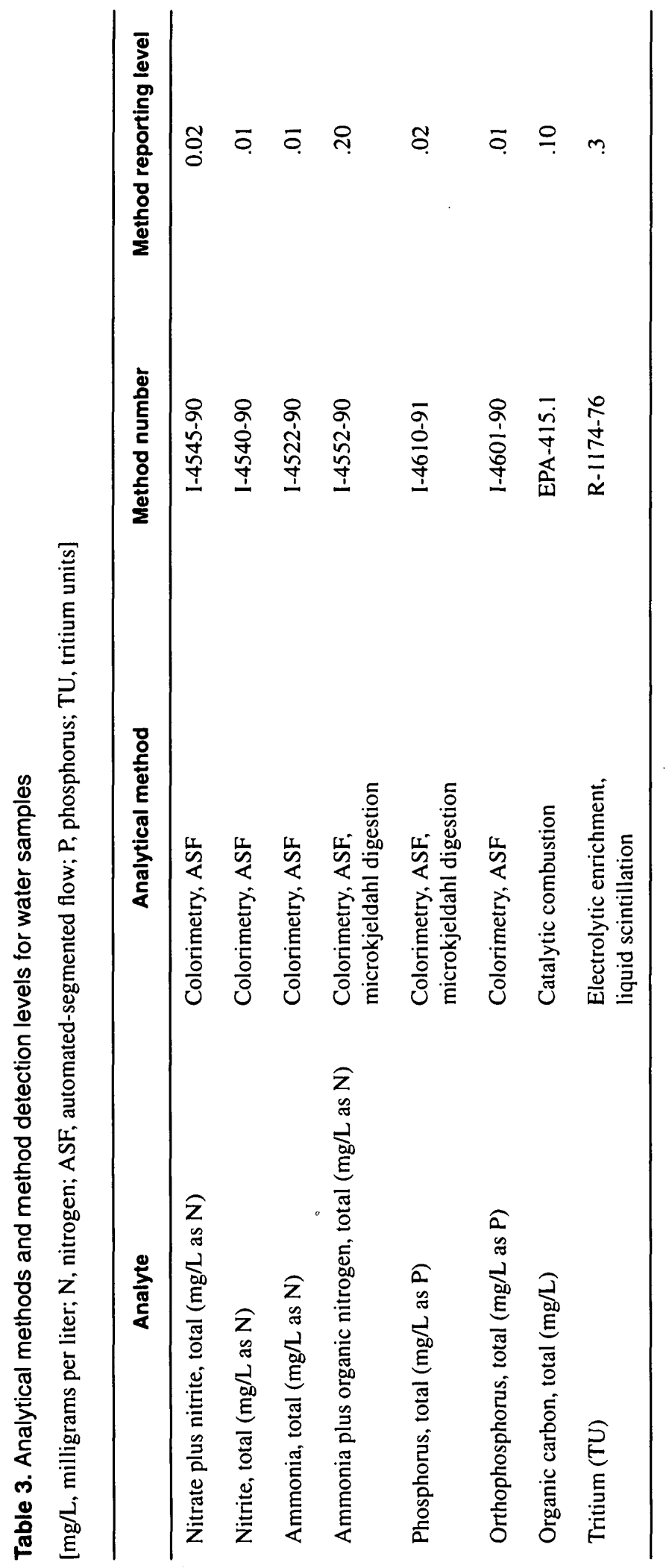


Twenty-two quality-assurance samples were collected at 19 PWS wells during the two rounds of sampling. The quality-assurance samples included 8 field blanks collected to monitor for contamination and carryover between environmental samples and 14 replicate environmental samples collected to monitor analytical precision. Nutrients and total organic carbon were analyzed in the field blanks and replicate samples. Most constituent concentrations were below the method reporting level (MRL) in the eight field blanks with the following exceptions: (1) total ammonia detected in five field blanks [MRL 0.01 milligrams per liter $(\mathrm{mg} / \mathrm{L})$; detected concentrations ranged from 0.01 to $0.02 \mathrm{mg} / \mathrm{L})$ ]; (2) total phosphorus detected in one field blank (MRL $0.02 \mathrm{mg} / \mathrm{L}$; detected concentration $0.02 \mathrm{mg} / \mathrm{L}$ ); (3) total orthophosphorus detected in one field blank (MRL $0.01 \mathrm{mg} / \mathrm{L}$; detected concentration $0.02 \mathrm{mg} / \mathrm{L}$ ); and total organic carbon detected in one field blank (MRL $0.10 \mathrm{mg} / \mathrm{L}$; detected concentration $0.20 \mathrm{mg} / \mathrm{L}$ ). Nutrient and total organic carbon concentrations in the replicate environmental samples were comparable in most cases and well within laboratory analytical error.

Figure 11. Results of enteric virus, coliphage, and indicator bacteria analyses for samples collected at selected public-water-supply wells.

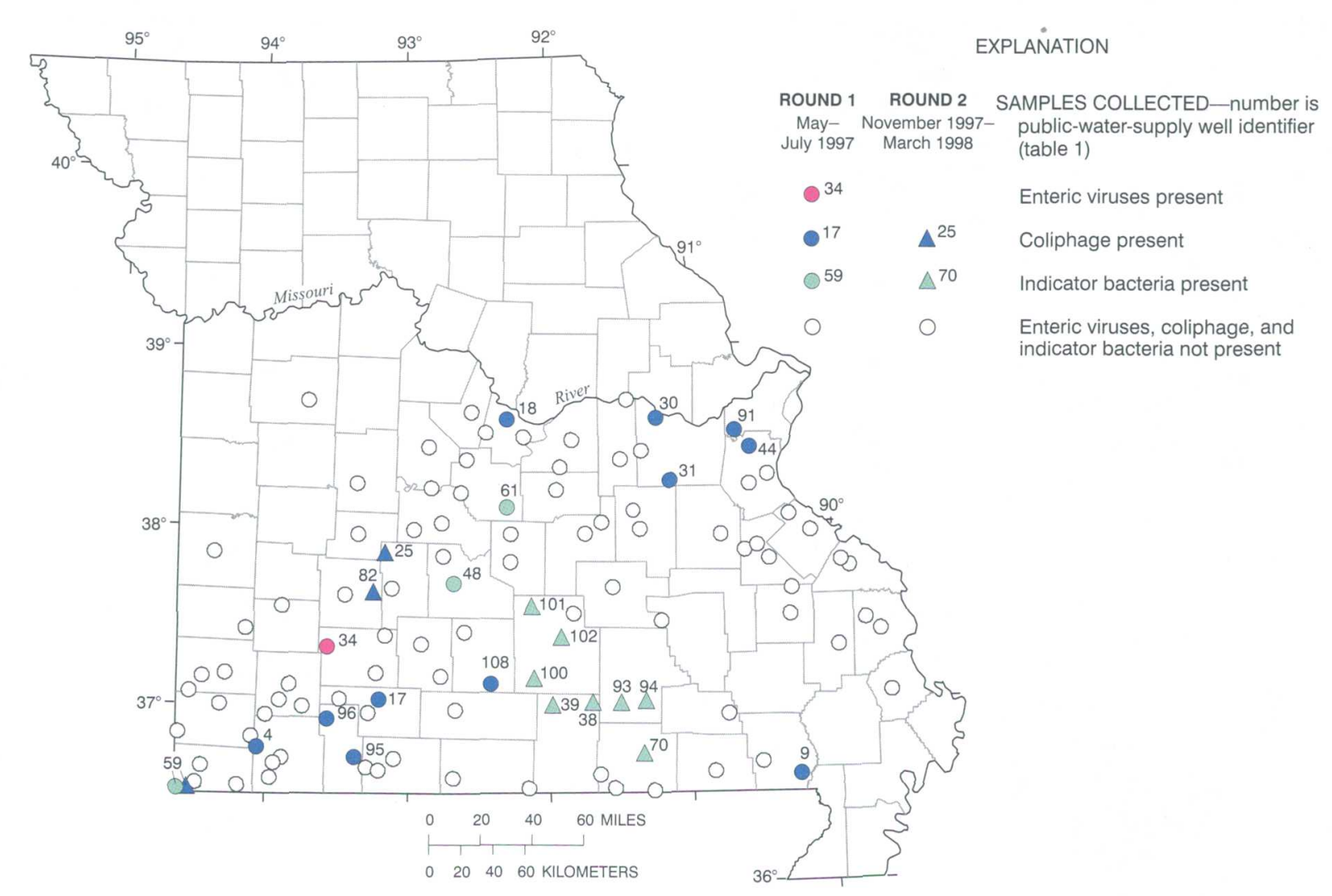

\section{MICROBIOLOGICAL QUALITY}

The microbiological data indicate that microbiological contamination at PWS wells in the Ozark Plateaus aquifer system is not widespread (fig. 11; table 2 ). A relatively small percentage of the wells show contamination by potentially pathogenic viruses or other pathogen indicator organisms. Of the 109 PWS wells sampled during the first round, 94 ( 86 percent) showed no presence of microbiological contamination. Human enteric viruses (as determined by the ICR method) were present in a sample from 1 of the 109 PWS wells (well 34) at a concentration of 2.1 MPN/100 L. Additional testing of the sample from well 34 indicates that the isolate was not likely a member of the poliovirus group but is probably a member of the echovirus or coxsackie groups (Dr. James A. Vaughn, University of New England, written commun., January 2000). According to the PDWP, well 34 had one instance of unsafe total coliform bacteria results in October 1996 (T. Eichholz, Missouri Department of Natural Resources, written commun., 1998). At the time of sampling, well 34 was part of a threewell PWS system that did not routinely chlorinate

analyses for samples collected at selected public-water-supply wells. 
(table 1). Coliphage were observed in samples collected from 11 of the 109 wells $(4,9,17,18,30,31$, $44,91,95,96$, and 108) at concentrations ranging from 38 to 2,600 PFU/100 L. Well 9 is a control site located in the Mississippi Alluvial Plain (fig. 9). Fecal indicator bacteria were observed at small densities in samples from three PWS wells $(48,59$, and 61). Samples from two wells had 1 colony per 100 milliliters (col/100 mL) of fecal coliform bacteria, and a sample from one well had $1 \mathrm{col} / 100 \mathrm{~mL}$ of fecal streptococci. Public-water supplies from wells 4, 44, 48, 61, 95, and 108 are chlorinated (table 1). Of the 109 PWS wells sampled during the second round, 98 (90 percent) showed no presence of microbiological contamination. Coliphage were present in samples from three wells $(25,59$, and 82$)$ at concentrations ranging from 41 to $78 \mathrm{PFU} / 100 \mathrm{~L}$, including one well (59) for which fecal indicator bacteria were detected during the first round of sampling. Fecal streptococci bacteria were detected in samples from eight wells at densities ranging from 15 to $50 \mathrm{col} / 100 \mathrm{~mL}$ (wells $38,39,70,93,94,100$, 101 , and 102). Public-water supplies from wells 39 , 93, and 100 are chlorinated (table 1).

Contrary to what might be expected, most of the enteric virus and coliphage contamination was observed outside of the areas characterized as primary and secondary karst (figs. 9 and 11). The entericvirus-positive sample and 10 of the 13 coliphage-positive samples in the Ozark Plateaus were found in PWS wells located in the area where the Ozark aquifer is confined by the Ozark confining unit [C(OzCU)] (wells 4, 17, 34, 59, 95, and 96) or in the area where the Ozark aquifer is unconfined and where the karst is considered to be nonsignificant [U/NK(Oz)] (wells 18, $25,30,31$, and 82 ). Only one coliphage-positive sample was collected from a well (108) located in the area where the Ozark aquifer is unconfined and karstic $[\mathrm{U} / \mathrm{K}(\mathrm{Oz})]$. Because most of the PWS wells sampled are open to multiple water-bearing units, it is not possible to determine if any formations are inherently more susceptible to viral and bacterial contamination than others. The locations of the enteric-virus-, coliphage-, and indicator-bacteria-positive PWS wells from the first round of sampling generally are associated with the counties that have the most intense agricultural land use or have an estimated 1997 population of greater than 30,000 and/or have experienced an estimated population increase of greater than 10 percent from 1990 to 1997 (figs. 3 and 6). Waste from private septic systems and municipal wastewater-treatment plants are potential sources of microbiological contamination to ground water. None of the 32 samples tested for bovine and porcine enteric viruses were positive (table 2).

In a study done for the USEPA by SAIC (Science Applications International Corporation), information was collected on geohydrologic setting, well construction, and potential sources of fecal contamination at 21 PWS wells in which enteric viruses were detected (Science Applications International Corporation, 1998), including the 1 PWS well (well 34) for which enteric virus was detected in this study. These wells were located in Alabama ( 3 wells), Idaho ( 1 well), Minnesota (2 wells), Missouri (13 wells), North Carolina ( 1 well), and Oregon ( 1 well). Information was obtained from ongoing or completed studies in the surrounding area within $500 \mathrm{ft}$ of each of the 21 PWS wells, and an attempt was made to identify possible virus sources that would account for the presence of viruses in the wells (Science Applications International Corporation, 1998). Close proximity to sewer lines and septic systems and surface-water bodies frequently were identified as potential sources of viral contamination. Karst geohydrologic setting was considered a contributing factor to viral contamination in four wells.

The eight fecal-streptococci-positive PWS wells from the second round of sampling are located in the karst area (figs. 9 and 11). One sample was collected on December 3, 1997, and the other seven were collected between December 9 and 11 (table 2). Dry conditions in this area during November were followed by rainfall at the end of November and beginning of December. It is not uncommon in this area of mature karstic features for contaminants at or near land surface to rapidly enter the ground-water system after precipitation (James Vandike, Missouri Department of Natural Resources, oral commun., 1998).

Results varied considerably between the first and second rounds of sampling. Also, enteric viruses and coliphage were not present in the same sample, and no indicator bacteria were present in any sample with enteric viruses or coliphage. A study done by the USEPA yielded similar results (Lieberman and others, 1994). Twenty-nine PWS wells located in 17 states plus Puerto Rico and the Virgin Islands were sampled monthly for 1 year and analyzed for enteric viruses, coliphage, fecal indicator bacteria, and other potential enteric virus indicator organisms. An average of 6,000 L of water were filtered for enteric virus and coliphage 
analysis. The wells were selected because of their perceived vulnerability to human fecal contamination. Vulnerability was determined through an assessment of historical occurrence of fecal indicator bacteria, known sources of human fecal contamination in close proximity to the well, and geohydrologic setting (porous media, karst, or fractured rock). Three of the PWS wells sampled were located in a karstic geohydrologic setting in Alabama. One or more of the fecal indicators were detected in 26 of the 29 wells sampled, and enteric viruses were detected in 20 samples from 7 wells, including the 3 wells located in a karstic geohydrologic setting in Alabama. Results varied from month to month from the same well. Also, the relation between the occurrence of enteric viruses and the various fecal indicators showed only a weak positive correlation. The presence or absence of a fecal indicator in a sample was not a predictor for enteric virus occurrence in that sample. However, a well that was entericvirus- or fecal-indicator-positive one month would tend to be positive another month (Lieberman and others, 1994). A site-by-site correlation would not be determinable yet for the Ozark Plateaus study because each well was sampled only twice. An increased sampling frequency would increase the probability of a site-by-site correlation.

Enteric virus results also varied depending on the analytical method used (table 2). The sample from well 34 was enteric-virus positive by the ICR method but was negative by the integrated-cell-culture PCR method. Conversely, samples from 13 wells (wells 10 , $12,18,29,48,53,66,74,76,83,89,90$, and 103; table 2) that were enteric-virus negative by the ICR method were positive by the PCR method. According to Dr. James Vaughn (University of New England, oral commun., 1998), this is not an unexpected result. Very low numbers of enteric viruses, if any, are present in the samples and may or may not be detected by the ICR or PCR method. Also, the sample concentrates were frozen for up to several months before PCR analysis, and the long storage times may have caused loss of viruses, resulting in a negative result by PCR. Finally, some enteric viruses may have a positive result by PCR, but do not produce cytopathic effect, producing a negative result by ICR.

\section{CHEMICAL QUALITY}

The physical property, nutrient, organic carbon, and tritium data were evaluated to determine the vari- ability in chemical quality between the PWS wells sampled (table 2). Statistical summaries of the physical property and chemical data collected during this study are listed in table 4.

The distributions of selected physical property and chemical constituents of the $\mathrm{C}(\mathrm{OzCU}), \mathrm{U} / \mathrm{NK}(\mathrm{Oz})$, and $\mathrm{U} / \mathrm{K}(\mathrm{Oz})$ grouped data were graphically displayed using truncated, side-by-side boxplots (Helsel and Hirsch, 1992, p. 26). Insufficient data were available for $\mathrm{U} / \mathrm{NK}(\mathrm{SF}), \mathrm{O}, \mathrm{Unc}$, and $\mathrm{C}(\mathrm{W})$ to include in this analysis (fig. 9). The boxplots show five percentiles of the data distribution: 10th, 25th, 50th (median), 75th, and 90th. Boxplots constructed with censored data (data reported as below some threshold) were modified by making the lower limit of the box equal to the MRL. The nonparametric Kruskal-Wallis analysis-of-variance test (Helsel and Hirsch, 1992, p. 163) was used to test for differences in the distributions of the data, among groups. The distributions were considered significantly different from one another if the probability ( $p$-value) is less than 5 percent (less than 0.05 ) that the observed difference occurs by chance. If a statistically significant difference was detected among the data groups, individual differences were evaluated by applying Tukey's multiple comparison test to the ranktransformed data (Helsel and Hirsch, 1992, p. 196).

\section{Physical Properties}

The measurement of the physical properties of ground water can provide information on the solubility and rate of dissolution of rock minerals, hydrogen-ion activity, ionic concentration, recharge to the groundwater system, and potential for some kinds of waterrock interaction (Hem, 1985). The physical properties of ground water may vary considerably depending on the characteristics of the aquifer. Statistical summaries of the physical property data, including water temperature, specific conductance, $\mathrm{pH}$, dissolved oxygen, and alkalinity, for all 109 PWS wells are listed in table 4. Boxplots of specific conductance and dissolved oxygen for the grouped data are shown in figure 12.

Specific conductance values, which provide an indication of the dissolved-solids content of the water, differed significantly among samples for PWS 


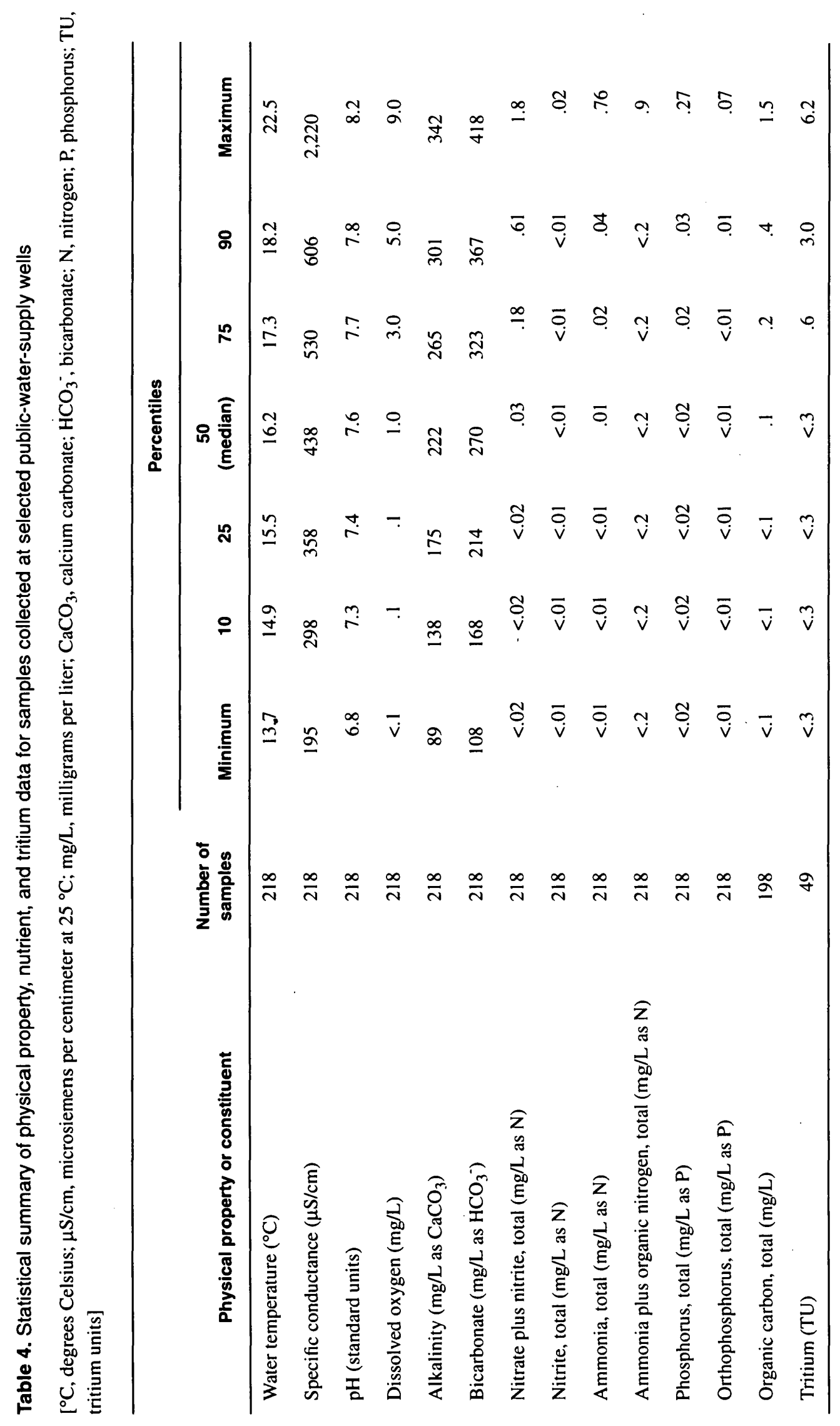



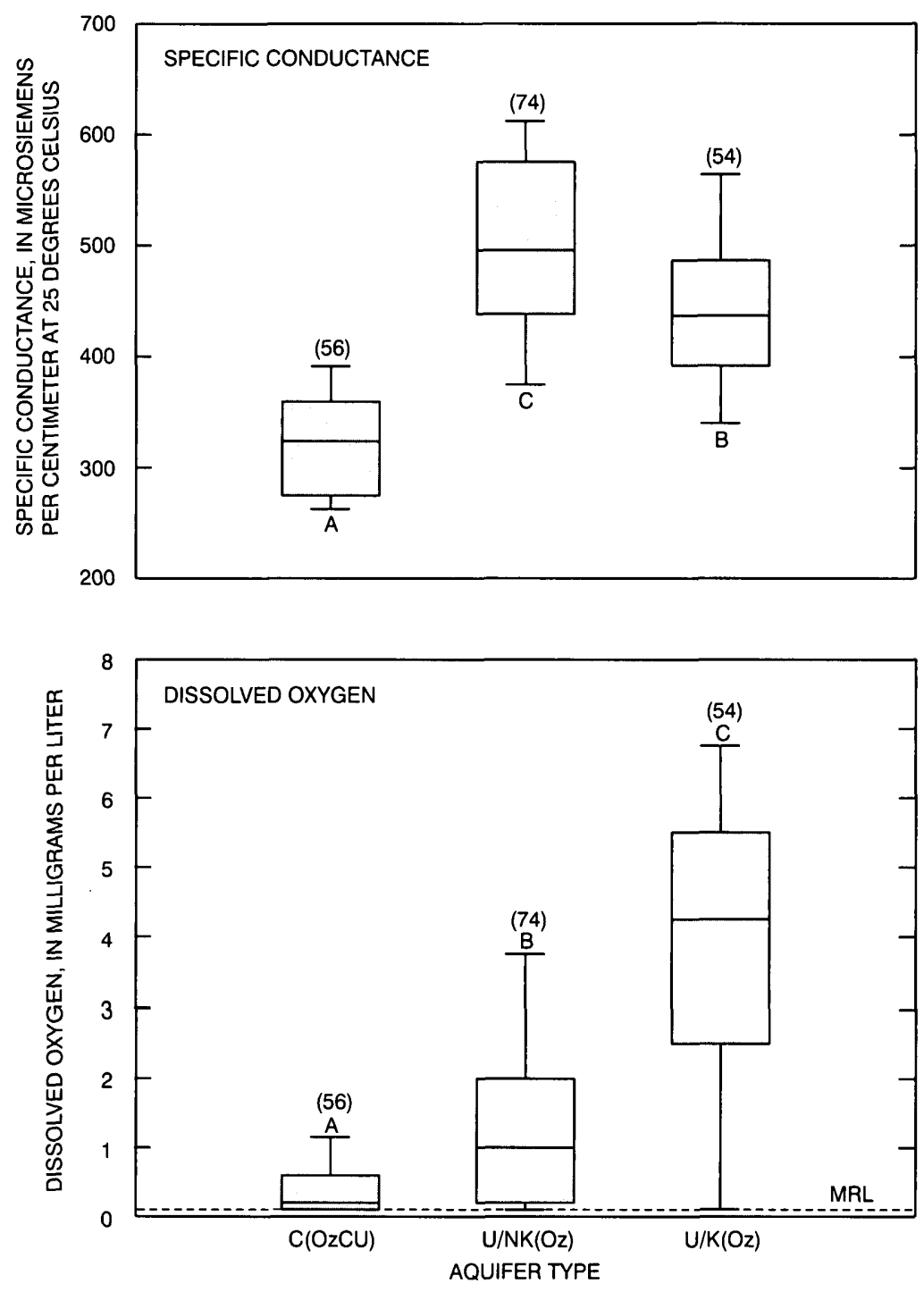

EXPLANATION

(56)
NUMBER IN PARENTHESES-Number

of analyses included in computation

of percentiles

A

DISTRIBUTIONS ASSOCIATED WITH THE SAME LETTER ARE NOT SIGNIFICANTLY $(p<0.05)$ DIFFERENT
MRL METHOD REPORTING LEVEL

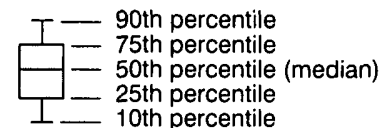

AQUIFER TYPE-

$\mathrm{C}(\mathrm{OzCU})$ Ozark aquifer overlain by Springfield Plateau aquifer and confined by Ozark confining unit $\mathrm{U} / \mathrm{NK}(\mathrm{Oz})$ Ozark aquifer unconfined; nonsignificant karst features

$\mathrm{U} / \mathrm{K}(\mathrm{Oz}) \quad$ Ozark aquifer unconfined; primary and secondary karst features

Figure 12. Statistical distribution of specific conductance and dissolved-oxygen concentrations of selected public-water-supply wells grouped by aquifer type. 
wells located in the three aquifer types- $\mathrm{C}(\mathrm{OzCU})$, $\mathrm{U} / \mathrm{NK}(\mathrm{Oz})$, and $\mathrm{U} / \mathrm{K}(\mathrm{Oz})$ (fig. 12). Values ranged from 195 to 801 microsiemens per centimeter at $25^{\circ} \mathrm{C}(\mu \mathrm{S} / \mathrm{cm})$, and the median values were 324,496 , and $437 \mu \mathrm{S} / \mathrm{cm}$ for $\mathrm{C}(\mathrm{OzCU}), \mathrm{U} / \mathrm{NK}(\mathrm{Oz})$, and $\mathrm{U} / \mathrm{K}(\mathrm{Oz})$, respectively. According to Imes and Davis (1991), the dissolved-solids content of water in the Ozark aquifer generally reflects the movement of the water from regional ground-water divides toward major discharge areas. The smallest dissolved-solids concentrations generally occur along a major ground-water divide (fig. 13) that extends from southwestern Missouri to the St. Francois Mountains of southeastern Missouri. Away from the divide the dissolved-solids content increases, particularly in the north-central, northeastern, and northwestern parts of Missouri south of the Missouri River. The specific conductance values, as well as alkalinity concentrations, generally follow this pattern (fig. 13). The smallest specific conductance values occur in southwestern Missouri where the Ozark aquifer is confined.
Dissolved-oxygen concentrations also differed significantly among samples for PWS wells located in $\mathrm{C}(\mathrm{OzCU}), \mathrm{U} / \mathrm{NK}(\mathrm{Oz})$, and $\mathrm{U} / \mathrm{K}(\mathrm{Oz})$ (fig. 12). Concentrations ranged from less than 0.1 to 9.0 milligrams per liter $(\mathrm{mg} / \mathrm{L})$, and median concentrations were $0.2,1.0$, and $4.2 \mathrm{mg} / \mathrm{L}$ for $\mathrm{C}(\mathrm{OzCU}), \mathrm{U} / \mathrm{NK}(\mathrm{Oz})$, and $\mathrm{U} / \mathrm{K}(\mathrm{Oz})$, respectively. These results appear to relate directly to whether or not the Ozark aquifer is confined or unconfined and to the degree of karst development (figs. 9 and 14). The smallest dissolved-oxygen concentrations generally occurred in southwestern Missouri where the Ozark aquifer is confined and in the northcentral part of the study area where the Ozark aquifer is unconfined and karst features are not extensively developed. The largest concentrations generally occurred in the south-central and eastern parts of the study area where the Ozark aquifer is unconfined and karst features are extensively developed or where the St. Francois aquifer is unconfined.

EXPLANATION

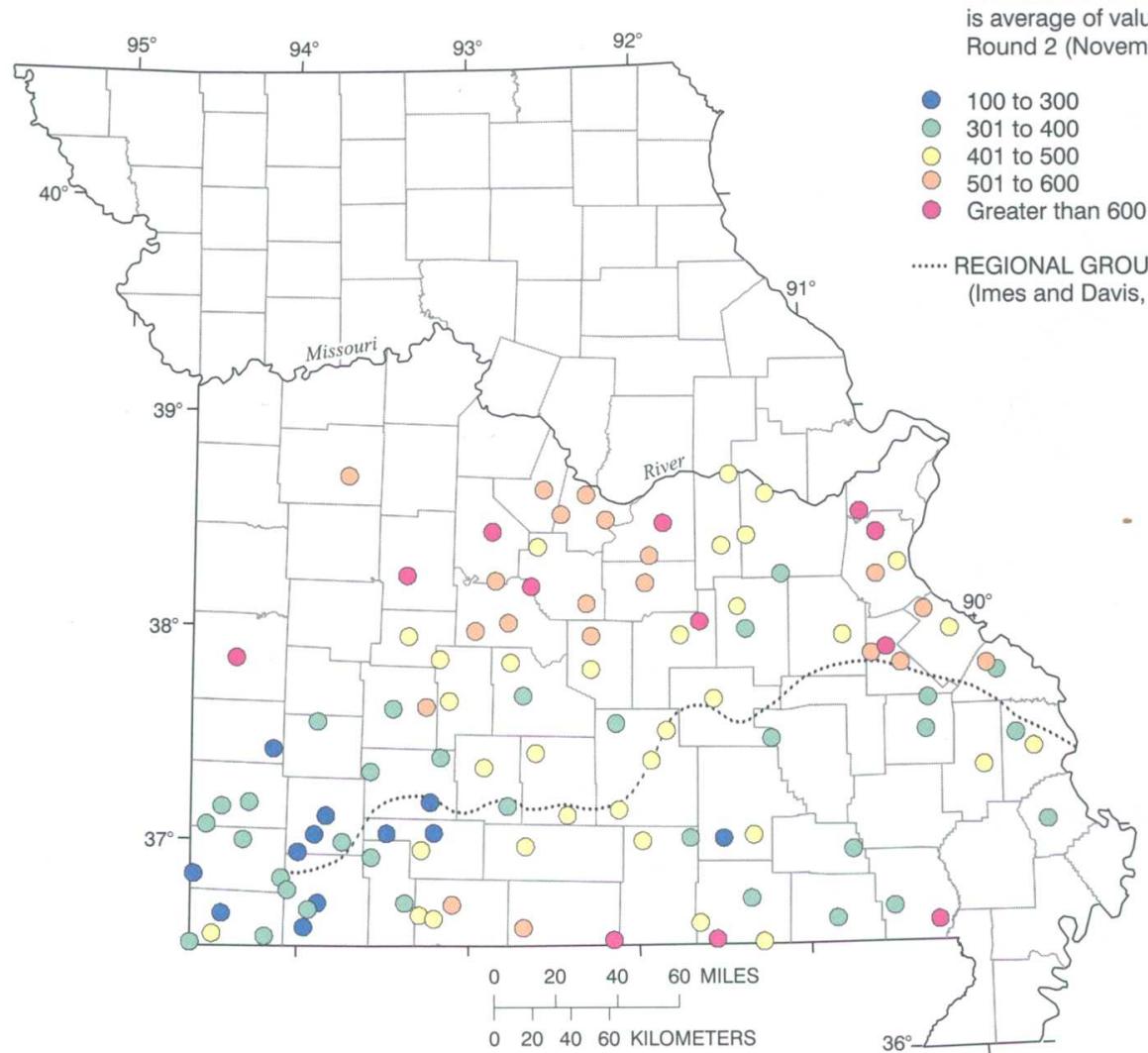

SPECIFIC CONDUCTANCE VALUE, IN MICROSIEMENS PER CENTIMETER AT 25 DEGREES CELSIUS-Value is average of values from Round 1 (May-July 1997) and Round 2 (November 1997-March 1998)

Greater than 600

REGIONAL GROUND-WATER DIVIDE (Imes and Davis, 1991)

Figure 13. Specific conductance values at selected public-water-supply wells. 


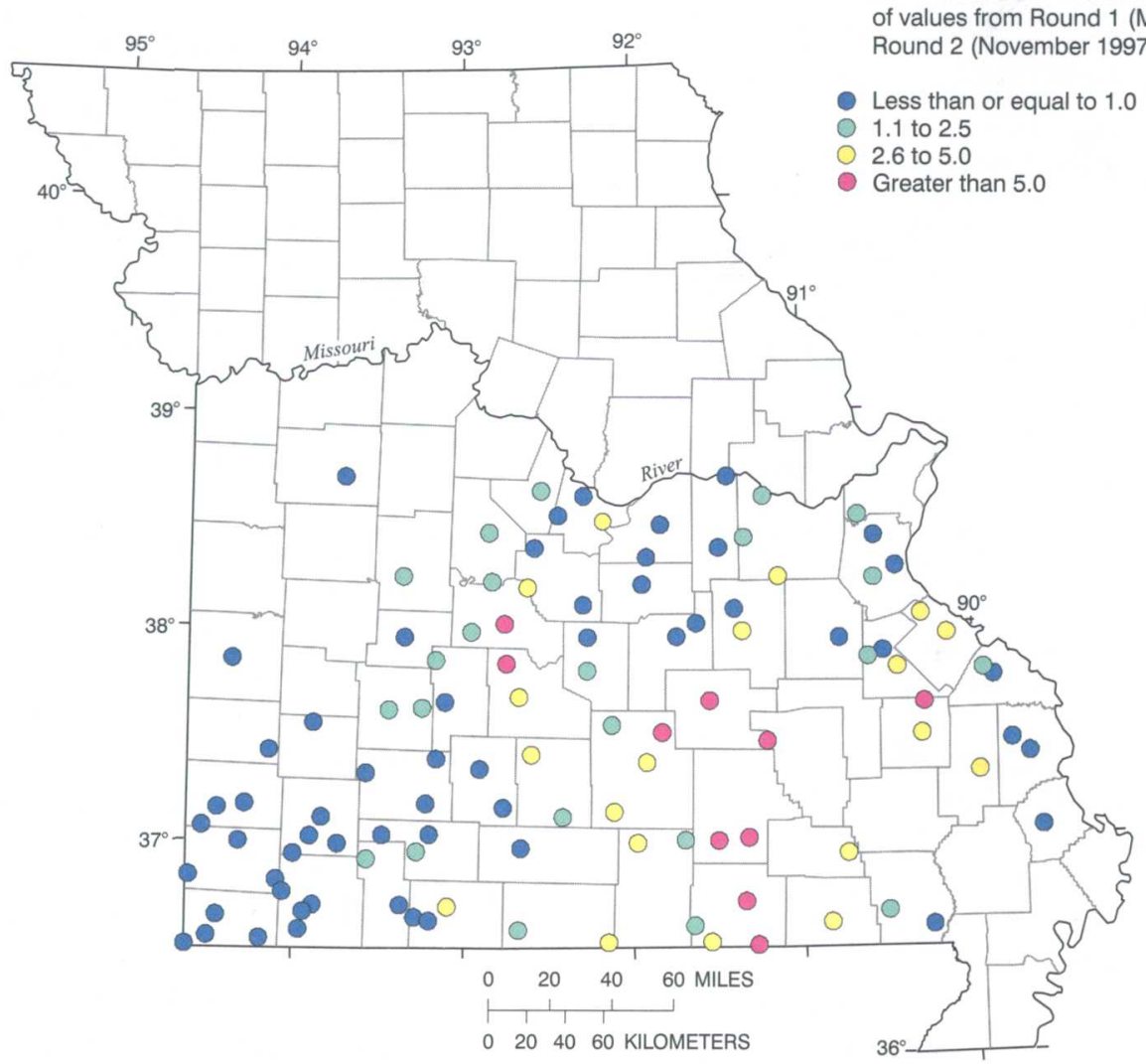

DISSOLVED OXYGEN CONCENTRATION, IN MILLIGRAMS PER LITER-Value is average of values from Round 1 (May-July 1997) and Round 2 (November 1997-March 1998)

Less than or equal to 1.0

2.6 to 5.0

Greater than 5.0

Figure 14. Dissolved-oxygen concentrations at selected public-water-supply wells.

\section{Nutrients}

Nutrients, including nitrogen and phosphorus species and organic carbon, can have detrimental effects upon desired uses of water and may serve as indicators of possible contamination. Major sources of nutrients in the study area are poultry, cattle, hog, and human wastes, and fertilizers. A likely source of ammonia in a well is a septage plume in close proximity to its septic-tank drainfield source. The USEPA has established a maximum contaminant level (MCL) of $10 \mathrm{mg} / \mathrm{L}$ for nitrate (as nitrogen) in public-drinkingwater supplies (U.S. Environmental Protection Agency, 1988) because high concentrations of nitrate can cause blue-baby syndrome in infants. The nutrients analyzed in this study include total nitrate plus nitrite, nitrite, ammonia, ammonia plus organic nitrogen, phosphorus, orthophosphorus, and organic carbon. Statistical summaries of the nutrient data for all 109 PWS wells are listed in table 4.
Total nitrate plus nitrite concentrations differed significantly among samples for PWS wells located in $\mathrm{C}(\mathrm{OzCU}), \mathrm{U} / \mathrm{NK}(\mathrm{Oz})$, and $\mathrm{U} / \mathrm{K}(\mathrm{Oz})$ (fig. 15). Concentrations ranged from less than 0.02 to $1.8 \mathrm{mg} / \mathrm{L}$, and median concentrations were less than $0.02,0.02$, and $0.20 \mathrm{mg} / \mathrm{L}$ for the $\mathrm{C}(\mathrm{OzCU}), \mathrm{U} / \mathrm{NK}(\mathrm{Oz})$, and $\mathrm{U} / \mathrm{K}(\mathrm{Oz})$, respectively. No total nitrate plus nitrite concentration exceeded the MCL of $10 \mathrm{mg} / \mathrm{L}$ as nitrogen. The results appear to relate directly to whether or not the Ozark aquifer is confined or unconfined and to the degree of karst development, and not to land use or population. Concentrations generally were smallest in southwestern Missouri and the north-central parts of the study area, which are the areas with the largest population and most intense urban and agricultural land use (figs. 3,6 , and 16). This result is the opposite from that obtained for the enteric viruses and coliphage (fig. 11). Total organic carbon concentrations displayed a similar pattern to that of total nitrate plus nitrite concentrations. Differences in total nitrite, ammonia, ammonia plus organic nitrogen, phosphorus, and orthophospho- 


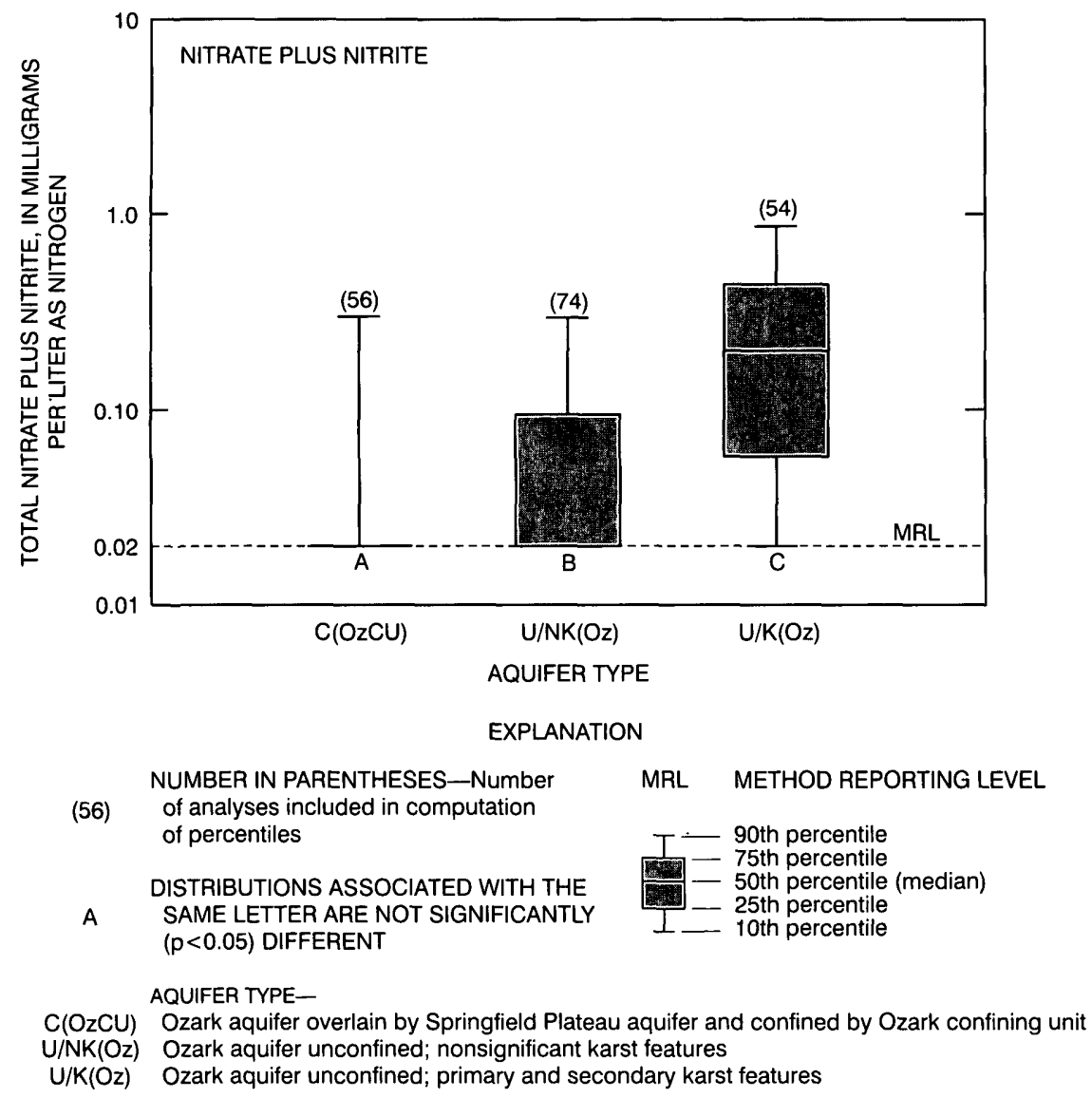

Figure 15. Statistical distribution of total nitrate plus nitrite concentrations of selected public-water-supply wells grouped by aquifer type.

rus concentrations among the aquifer types were statistically significant but not practically significant.

\section{Tritium}

Determining the age of ground water in an aquifer can help to explain existing microbiological and chemical contamination. In addition, where contamination has not occurred, age dating of ground water may provide resource managers with a tool to make informed decisions on resource management. This study employed the use of the hydrogen isotope tritium to develop an understanding of the residence time of ground water from selected wells in the Ozark Plateaus aquifer system. The relation between the age of ground water and the observed microbiological, physical, and chemical factors in the aquifer was studied.

Tritium has been used extensively as a hydrologic tracer since the early 1950's (Slack and Oakley, 1989, 1991, and 1992; Bartholomay, 1993; Osmond,
1971; and Plummer and others, 1993) and can be used to indicate the relative age of water (pre- or post1953). Tritium is particularly useful in ground-water studies because it is relatively unaffected by reactions other than its radioactive decay. Tritium is a radioactive isotope of hydrogen with a mass of 3 and a halflife of 12.43 years. Tritium is produced naturally and occurs in a small but nearly constant concentration in the atmosphere (Lal and Peters, 1967). Prior to the beginning of atmospheric testing of large thermonuclear weapons in 1953, the natural tritium content of rainwater was about 1 to 5 tritium units (TU) or 1 to 5 tritium atoms per 1,018 normal hydrogen atoms (Thatcher, 1962). In the 1950's and 1960's, tritium concentrations in precipitation in the northern hemisphere increased substantially as a result of weapons testing, to values of about $50 \mathrm{TU}$ for surface ocean water and 100 to $1,000 \mathrm{TU}$ for some continental water. The USGS has maintained a network of stations to collect precipitation and river water samples for tritium analyses since the early 1960s (Michel, 1989). 


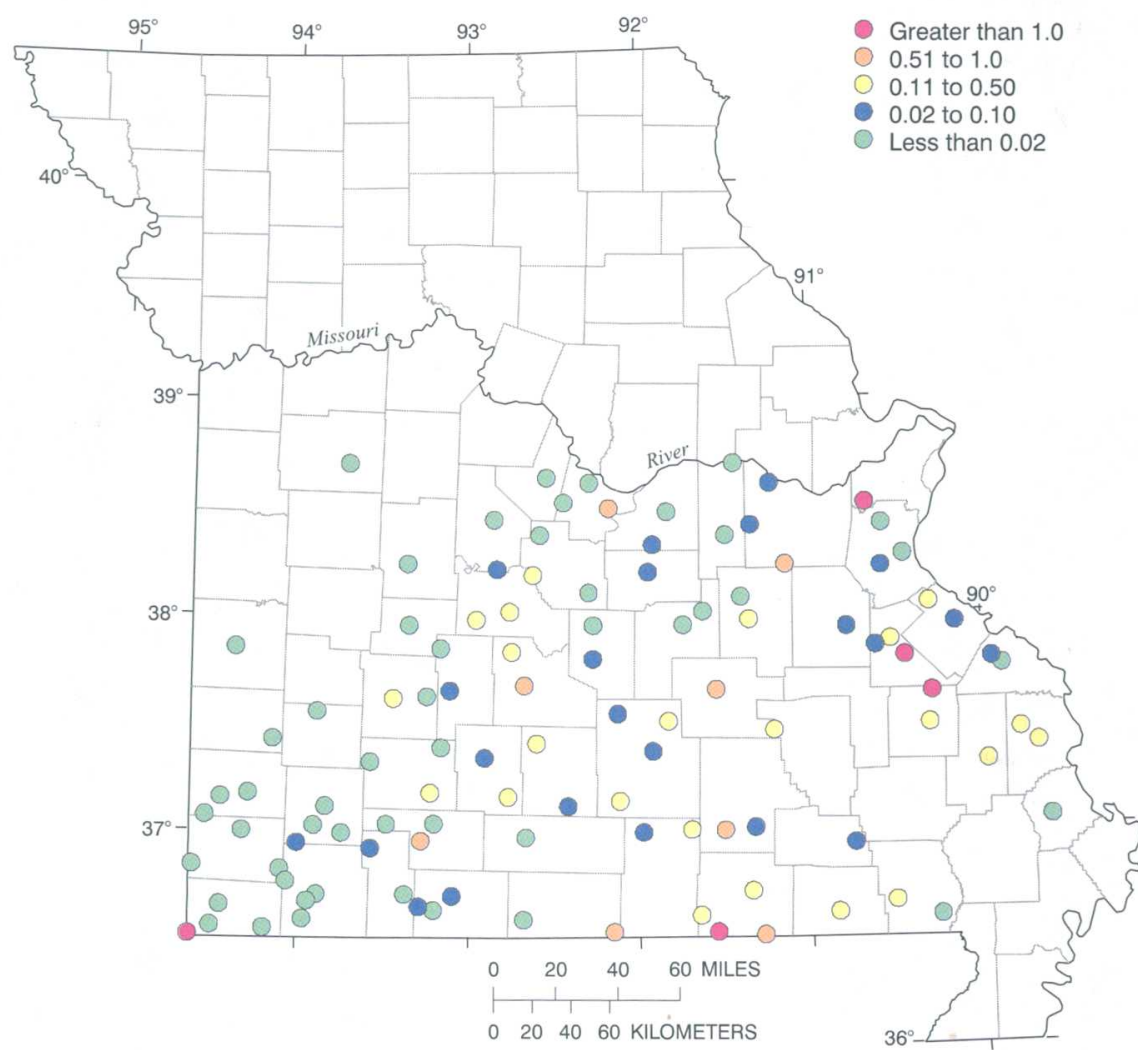

(November 1997-March 1998)

0.51 to 1.0

0.11 to 0.50

0.02 to 0.10

Less than 0.02

Figure 16. Total nitrate plus nitrite concentrations at selected public-water-supply wells.

The weighted averages of tritium concentrations in precipitation in the St. Louis area from 1953 to 1992 , adjusted for decay to 1997 values, are shown in figure 17. Ground waters derived exclusively from precipitation before weapons testing would have maximum tritium concentrations of 0.2 to $0.8 \mathrm{TU}$ by the early 1990 s due to decay. For ground waters with higher tritium concentrations, some fraction of the water must have been derived since the advent of atmospheric testing of weapons (Plummer and others, 1993).

Samples from 49 of the 109 PWS wells sampled from May to July 1997 were analyzed for tritium concentration (fig. 18; table 2). Depths of the sampled wells range from 292 to $1,840 \mathrm{ft}$. Fifteen wells are located where the Ozark aquifer is unconfined and karstic $[\mathrm{U} / \mathrm{K}(\mathrm{Oz})] ; 12$ wells are located where the Ozark aquifer is unconfined and has nonsignificant karst features [U/NK(Oz)]; 2 wells are located where the St. Francois aquifer is unconfined and has nonsignificant karst features [U/NK(SF)]; and 13 wells are located where the Ozark aquifer is confined $[\mathrm{C}(\mathrm{OzCU})]$ (table 1; fig. 9). Two of the remaining seven wells are located in western Missouri $[\mathrm{C}(\mathrm{W})]$; and five wells are located in eastern Missouri $(\mathrm{O})$. With the exception of the two U/NK(SF) wells, all wells are open to at least one or more units of the Ozark aquifer (table 1). The Nevada PWS well, one of the wells in western Missouri, is open to the Springfield Plateau aquifer, the Ozark confining unit, and the Ozark aquifer (well 104; table 1).

Tritium concentrations in samples collected from 49 wells ranged from less than 0.3 to $6.2 \mathrm{TU}$. Thirty samples were at concentrations less than the reporting limit of $0.3 \mathrm{TU}$. Eight samples ranged from 0.3 to $0.8 \mathrm{TU}$, and 11 samples ranged from 1.0 to 6.2 TU (table 2). These data indicate that 38 wells produce water that is older than about 50 years and that the remaining 11 wells produce water that is a mixture of pre- and post-1953 recharge (fig. 18). Three wells $(75,93$, and 100$)$ in the $\mathrm{U} / \mathrm{K}(\mathrm{Oz})$ area, three wells $(8$, 


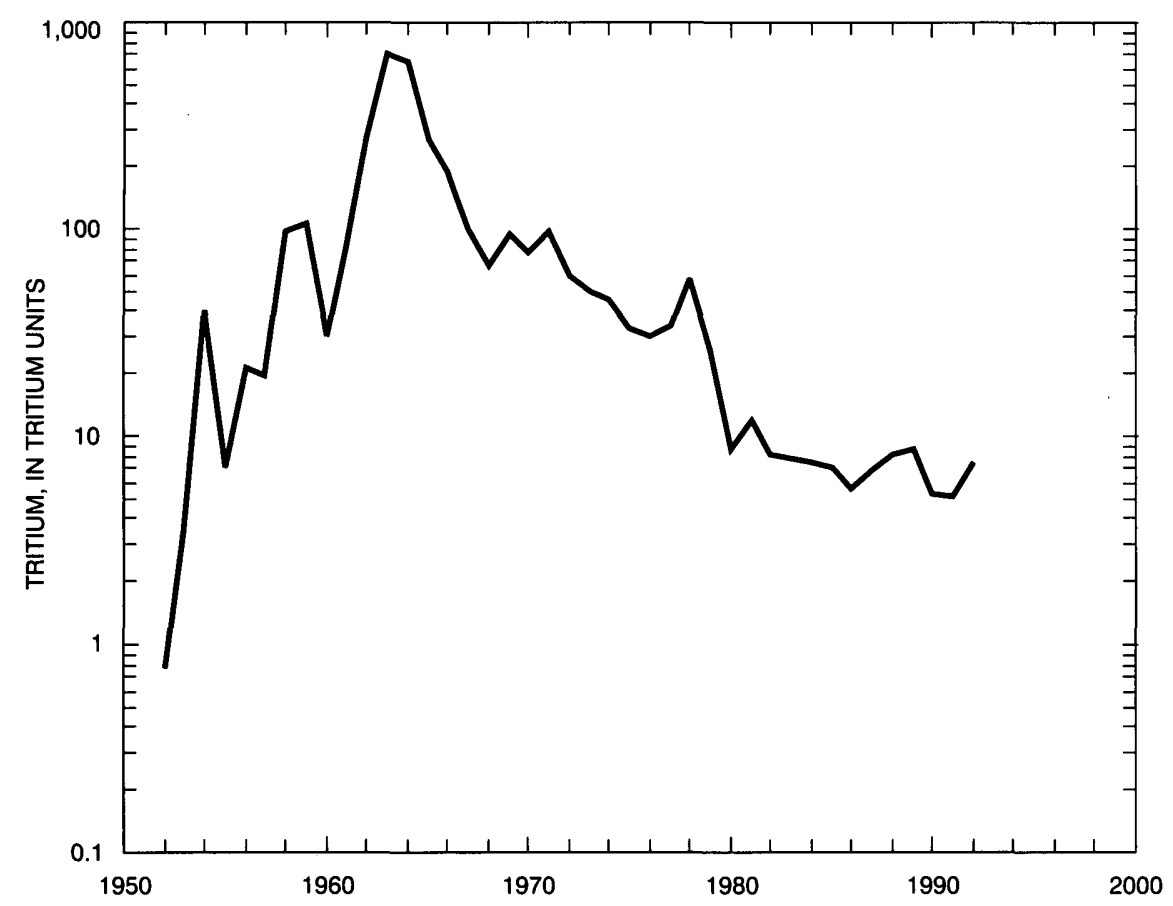

Figure 17. Weighted averages of tritium concentrations in precipitation in the St. Louis area from 1953 to 1992 , adjusted for decay to 1997 values.

31 , and 62) in the $\mathrm{U} / \mathrm{NK}(\mathrm{Oz})$ area, two wells (4 and $59)$ in the $\mathrm{C}(\mathrm{OzCU})$ area, two wells (54 and 86) in the $\mathrm{U} / \mathrm{NK}(\mathrm{SF})$ area, and one well (91) in the $\mathrm{O}$ area produced water with a tritium concentration indicating a mixture of pre- and post-1953 recharge.

Indicator bacteria were present in samples from 3 of the 49 wells that were sampled for tritium. One well was located in the $\mathrm{U} / \mathrm{K}(\mathrm{Oz})$ area (48), one in the $\mathrm{C}(\mathrm{OzCU})$ area (59), and one in the $\mathrm{U} / \mathrm{NK}(\mathrm{Oz})$ area (61). The sample from well 59 had a tritium concentration (6.2 TU; table 2) suggesting a mixture of pre- and post-1953 water. A sample from well 59 was also coliphage positive during the second round of sampling. Samples from wells 93, 94, 100, 101, and 102 [all located in the $\mathrm{U} / \mathrm{K}(\mathrm{Oz})$ area] were indicatorbacteria positive during the second round of sampling. Tritium samples collected from these wells during the first round of sampling indicate that wells 93 and 100 yield a mixture of pre- and post-1953 water (3.4 and 1.0 TU, respectively; table 2 ). Coliphage were detected in samples from 6 of 49 wells that were sampled for tritium. Coliphage concentrations in samples from these wells ranged from 38 to 2,600 $\mathrm{PFU} / 100 \mathrm{~L}$. Two wells were located in the U/NK(Oz) area (wells 30 and 31 ), two in the $\mathrm{C}(\mathrm{OzCU})$ area (4 and 17), and two in the $O$ area (44 and 91). Samples from wells 4,31 , and 91 had tritium concentrations $(4.1,1.8$, and 3.0 TU, respectively; table 2$)$ suggesting a mixture of pre- and post-1953 water. A tritium sample was not collected from well 34 which was enteric-virus positive. From these data, tritium concentration does not appear to be an indicator for the presence or absence of indicator bacteria or coliphage.

Tritium concentration and dissolved-oxygen and total nitrate plus nitrite concentrations generally follow similar patterns, however. The median dissolvedoxygen concentration was $3.5 \mathrm{mg} / \mathrm{L}$ (range of less than 0.1 to $8.5 \mathrm{mg} / \mathrm{L}$ ) in samples from the 11 wells with tritium concentrations indicating a mixture of pre- and post-1953 water. The median total nitrate plus nitrite concentration was $0.63 \mathrm{mg} / \mathrm{L}$ (range of less than 0.02 to $1.50 \mathrm{mg} / \mathrm{L}$ ) in samples from those same wells. The median dissolved-oxygen concentration was $0.6 \mathrm{mg} / \mathrm{L}$ (range of less than 0.1 to $8.0 \mathrm{mg} / \mathrm{L}$ ) in samples from the 38 wells with tritium concentrations indicating the absence of post-1953 water. The median total nitrate plus nitrite concentration was less than $0.02 \mathrm{mg} / \mathrm{L}$ (range of less than 0.02 to $0.79 \mathrm{mg} / \mathrm{L}$ ) in samples from those same wells (table 2). 


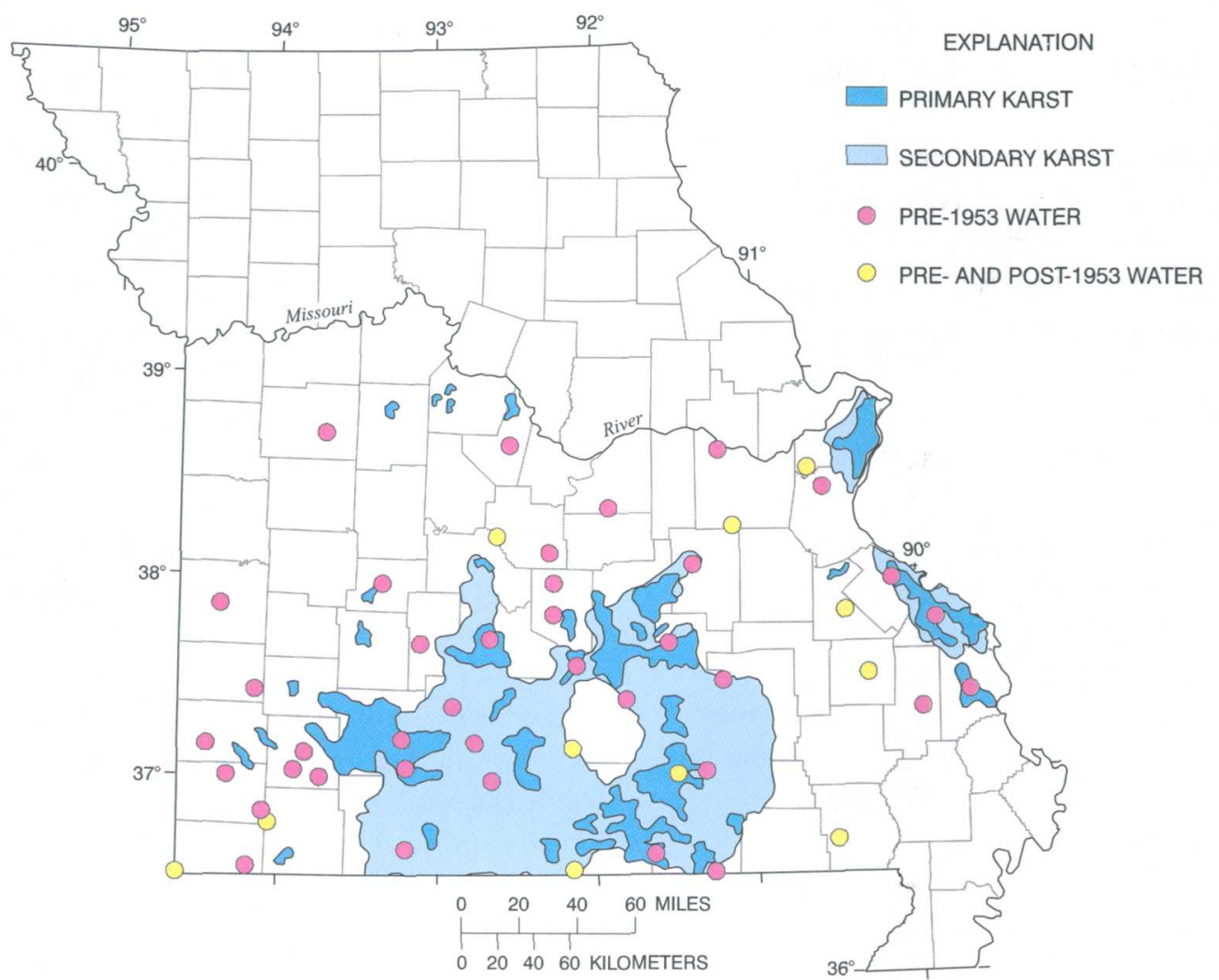

Figure 18. Pre- and post-1953 water from selected public-water-supply wells.

\section{SUMMARY}

Missouri is widely dependent on ground water as a source of drinking water for its public-water systems, businesses, farms, and rural homes. Ninety-five percent of the public-water systems in the State depend on ground water, and about 3,700 publicwater-supply wells are located within the State. Historically, water provided from the deep bedrock aquifers in the Ozark Plateaus generally has been free of total and fecal coliform bacterial contamination. Much is known about total and fecal coliform bacterial contamination, but little is known about viral contamination and its relation to the bacterial and chemical characteristics of the ground water.

The Ozark Plateaus aquifer system generally consists of carbonate rocks of Mississippian through Cambrian age, with numerous karst features, such as caves, springs, sinkholes, solution-enlarged fractures, and losing streams. The Springfield Plateau aquifer, the Ozark confining unit, the Ozark aquifer, the St. Francois confining unit, and the St. Francois aquifer collectively comprise the Ozark Plateaus aquifer system. The most important aquifer of the Ozark aquifer system for public supplies is the Ozark aquifer. The Ozark aquifer is used as a source of public-water supply, both where it is unconfined and where it is confined. The St. Francois aquifer is less important as a source of public-water supply. The St. Francois aquifer is used as a source of public-water supply, both where it is unconfined in its outcrop area, and near its outcrop area where it is confined and the overlying Ozark aquifer is thin or absent. The Springfield Plateau aquifer is not used as a source of public-water supply where it is unconfined.

Because surface and ground-water exchange is relatively free where karst features are well developed, karst aquifers are susceptible to contamination from surface or near-surface sources. The unconfined Ozark aquifer in south-central Missouri is considered most vulnerable to viral and bacterial contamination because of the large density of karst features. The unconfined Ozark aquifer in central and eastern Missouri is considered somewhat less vulnerable because the density of karst features is smaller. The confined Ozark aquifer in southwestern Missouri is considered to be the least vulnerable because of the presence of the overlying Ozark confining unit. The St. Francois 
aquifer, although not very karstic, is considered to be vulnerable to contamination because the aquifer is not confined.

The U.S. Geological Survey, in cooperation with the Missouri Department of Natural Resources, Division of Environmental Quality, Public Drinking Water Program, has conducted a two-phase study to characterize the microbiological and chemical quality of ground water in the Ozark Plateaus aquifer system, which underlies the Ozark Plateaus region. During Phase I of the study, 109 public-water-supply wells were sampled in water year 1997 and again in water year 1998. Only community wells constructed in the last 15 years were considered initially. Additional well-selection criteria included availability of well construction and completion records, well operation and maintenance history, current usage, and geology. Most of the 105 public-water-supply wells located in the Ozark Plateaus are open to two or more waterbearing formations in the Ozark aquifer.

Samples from each public-water-supply well were analyzed for the following microbiological species-total human enteric viruses, male-specific and somatic coliphage, and fecal indicator bacteria. A subset of 32 samples from wells considered at risk for contamination from confined animal feeding operations were analyzed for bovine and porcine enteric viruses. In addition, samples were collected and analyzed for chemical constituents, such as nutrients, total organic carbon, and tritium, that may serve as indicators of possible surficial sources of contamination of the aquifer.

The microbiological data indicate that microbiological contamination at public-water-supply wells in the Ozark Plateaus aquifer system is not widespread. A relatively small percentage of the wells show contamination by potentially pathogenic viruses or other pathogen indicator organisms. Of the 109 publicwater-supply wells sampled during the first round, 94 (86 percent) showed no presence of microbiological contamination. Human enteric viruses were present in a sample from 1 of the 109 public-water-supply wells at a concentration of 2.1 most probable number per 100 liters. Coliphage were observed in samples collected from 11 of the 109 wells at concentrations ranging from 38 to 2,600 plaque forming units per 100 liters. Fecal indicator bacteria were observed at small densities in samples from three wells. Of the 109 wells sampled during the second round, 98 (90 percent) showed no presence of microbiological contamination, coliphage were present in samples from 3 wells at concentrations ranging from 41 to 78 plaque forming units per 100 liters, and fecal streptococci bacteria were observed in samples from 8 wells at densities ranging from 15 to 50 colonies per 100 milliliters. None of the 32 samples tested for bovine and porcine enteric viruses were positive. Results varied considerably between the first and second rounds of sampling. Also, no apparent correlation exists between the presence of enteric viruses and coliphage or indicator bacteria.

Most of the enteric virus and coliphage contamination was observed outside of the area with the most mature karst features. The enteric virus positive sample and 10 of the 13 coliphage positive samples in the Ozark Plateaus were found in samples from publicwater-supply wells located in the area where the Ozark aquifer is confined by the Ozark confining unit or in the area where the Ozark aquifer is unconfined and where the karst is considered to be nonsignificant. Because most of the wells sampled are open to multiple water-bearing units, it is not possible to determine if any formations are inherently more susceptible to viral and bacterial contamination than others. The location of the enteric virus, coliphage, and indicator bacteria positive public-water-supply wells from the first round of sampling generally correlate with the counties that have the most intense agricultural land use or have an estimated 1997 population of greater than 30,000 and/or have experienced an estimated population increase of greater than 10 percent from 1990 to 1997. The eight fecal streptococci positive PWS wells from the second round of sampling are located in the area with mature karst features and probably are related to hydrologic conditions at the time of sampling.

An evaluation of the physical property data indicated that specific conductance values and dissolvedoxygen concentrations differed significantly among samples from public-water-supply wells located in three defined areas of aquifer vulnerability-the confined Ozark aquifer in southwestern Missouri, the unconfined Ozark aquifer in central and eastern Missouri, and the unconfined Ozark aquifer in south-central Missouri. Median values were 324, 496, and 437 microsiemens per centimeter at $25^{\circ} \mathrm{C}$, respectively. The smallest values generally occurred along a major ground-water divide that extends from southwestern Missouri to the St. Francois Mountains of southeastern Missouri and increase away from the divide, particularly in the north-central, northeastern, and northwest- 
ern parts of southern Missouri. Median dissolvedoxygen concentrations for the three defined areas of aquifer vulnerability were $0.2,1.0$, and 4.2 milligrams per liter, respectively. These results appear to relate directly to whether or not the Ozark aquifer is confined or unconfined and the degree of karst development.

An evaluation of the nutrient data indicated that total nitrate plus nitrite concentrations differed significantly among samples from public-water-supply wells located in southwestern Missouri where the Ozark aquifer is confined, central and eastern Missouri where the Ozark aquifer is unconfined, or south-central Missouri where the Ozark aquifer is unconfined. Median concentrations were less than $0.02,0.02$, and 0.2 milligrams per liter, respectively. As with dissolved oxygen, these results appear to relate directly to whether or not the Ozark aquifer is confined or unconfined and the degree of karst development, and not to land use or population. This result is the opposite from that obtained for the enteric viruses and coliphage.

Tritium concentrations in samples collected from 49 public-water-supply wells during the first round ranged from less than 0.3 to 6.2 tritium units. Thirty samples had concentrations less than the reporting level of 0.3 tritium units, 8 samples ranged from 0.3 to 0.8 tritium units, and 11 samples ranged from 1.0 to 6.2 tritium units. Ground waters derived from precipitation prior to the 1953 nuclear-bomb testing are estimated to have a maximum present-day tritium concentration ranging from 0.2 to 0.8 tritium units. The data for the Ozark Plateaus aquifer system show that 38 wells produce water that is more than 50 years old and that the remaining 11 wells produce water that is a mixture of pre- and post-1953 recharge. No relation was seen between tritium concentration and presence of karst topography or microbiological contamination.

\section{REFERENCES}

Angulo, F.J., Tippen, S., Sharp, D.J., Payne, B.J., Collier, C., Hill, J.E., Barrett, T.J., Clar, R.M., Geldreich, E.E., Donnell, H.D., and Swerdlow, D.L., 1997, A community waterborne outbreak of salmonellosis and the effectiveness of a boil water order: American Journal of Public Health, v. 87, no. 4, p. 580-584.

Bartholomay, R.C., 1993, Concentrations of tritium and strontium-90 in water from selected wells at the Idaho National Engineering Laboratory after purging one, two, and three borehole volumes: U.S. Geological Sur- vey Water Resources Investigation Report 93-4201, $21 \mathrm{p}$.

Craun, G.F., 1984, Health aspects of groundwater pollution, in Bitton, G., and Gerba, C.P., eds., Groundwater pollution microbiology: New York, John Wiley \& Sons, p. $135-179$.

Craun, G.F., 1986, Statistics of waterborne outbreaks in the U.S. (1920-1980), in Craun, G.F., ed., Waterborne diseases in the United States: Boca Raton, Florida, CRC Press, Inc.

Craun, G.F., and Calderon, R., 1996, Microbial risks in groundwater systems-Epidemiology of waterborne outbreaks, in Under the microscope-Examining microbes in groundwater: Denver, Colorado, American Water Works Association Research Foundation, Groundwater Foundation Symposium Proceedings, Boston, Massachusetts, September 5-7, 1996, p. 9-21.

Davis, J.V., and Bell, R.W., 1998, Water-quality assessment of the Ozark Plateaus study unit, Arkansas, Kansas, Missouri, and Oklahoma-Nutrients, bacteria, organic carbon, and suspended sediment in surface water, 1993-95: U.S. Geological Survey Water-Resources Investigations Report 98-4164, 56 p.

Davis, J.V., Petersen, J.C., Adamski, J.C., and Freiwald, D.A., 1995, Water-quality assessment of the Ozark Plateaus study unit, Arkansas, Kansas, Missouri, and Oklahoma-Analysis of information on nutrients, suspended sediment, and suspended solids, 1970-92: U.S. Geological Survey Water-Resources Investigations Report 95-4042, 112 p.

Dugan, J.T., and Peckenpaugh, J.M., 1985, Effects of climate, vegetation, and soils on consumptive water use and ground-water recharge to the Central Midwest regional aquifer system, Mid-continent United States: U.S. Geological Survey Water-Resources Investigations Report 85-4236, 77 p.

Fishman, M.J., ed., 1993, Methods of analysis by the U.S. Geological Survey National Water Quality Laboratory-Determination of inorganic and organic constituents in water and fluvial sediments: U.S. Geological Survey Open-File Report 93-125, 217 p.

Fishman, M.J., and Friedman, L.C., eds., 1989, Methods for determination of inorganic substances in water and fluvial sediments: U.S. Geological Survey Techniques of Water-Resources Investigations, book 5 , chap. A1, $545 \mathrm{p}$.

Fenneman, N.M., 1938, Physiography of eastern United States: New York, McGraw-Hill Book Co., Inc., 689 p.

Geldreich, E.E., Fox, K.R., Goodrich, J.A., Rice, E.W., Clark, R.M., and Swerdlow, D.L., 1992, Searching for a water supply connection in the Cabool, Missouri disease outbreak of Escherichia coli 0157:H7: Water Research, v. 26 , no. 8 , p. 1,127-1,137.

Gerba, C.P., 1988, Methods for virus sampling and analysis of ground water, in Collins, A.G., and Johnson, A.I., 
eds., Ground-water contamination-Field methods: Philadelphia, American Society for Testing and Material, ASTM STP 963, p. 343-348.

Harvey, E.J., 1980, Ground water in the Springfield-Salem Plateaus of southern Missouri and northern Arkansas: U.S. Geological Survey Water-Resources Investigations Report 80-101, 66 p.

Hejkal, T.W., Keswick, B., LaBelle, R.L., Gerba, C.P., Sanchez, Y., Dreesman, G., Haskin, B., Melnick, J.L., 1982 , Viruses in a community water supply associated with an outbreak of gastroenteritis and infectious hepatitis: Journal of American Water Works Association, vol. 74, no. 6, pp. 318-321.

Helsel, D.R., and Hirsch, R.M., 1992, Statistical methods in water resources: Amsterdam, Netherlands, Elsevier, $522 \mathrm{p}$.

Hem, J.D., 1985, Study and interpretation of the chemical characteristics of natural water: U.S. Geological Survey Water-Supply Paper 2254, $263 \mathrm{p}$.

Imes, J.L., 1989, Analysis of the effect of pumping on ground-water flow in the Springfield Plateau and Ozark aquifers near Springfield, Missouri: U.S. Geological Survey Water-Resources Investigations Report 89-4079, $63 \mathrm{p}$.

Imes, J.L., 1990, Major geohydrologic units in and adjacent to the Ozark Plateaus province, Missouri, Arkansas, Kansas, and Oklahoma-Ozark aquifer: U.S. Geological Survey Hydrologic Investigations Atlas HA-711-E, 3 sheets.

Imes, J.L., and Davis, J.V., 1991, Water type and concentration of dissolved solids, chloride, and sulfate in water from the Ozark aquifer in Missouri, Arkansas, Kansas, and Oklahoma: U.S. Geological Survey Hydrologic Investigations Atlas HA-711-K, 1:750,000, 4 sheets.

Imes, J.L, and Emmett, L.F., 1994, Geohydrology of the Ozark Plateaus Aquifer System in parts of Missouri, Arkansas, Oklahoma, and Kansas: U.S. Geological Survey Professional Paper 1414-D, 127 p.

Lal, D., and Peters, B., 1967, Cosmic ray produced radioactivity on the earth, in Flugge, S., ed., Encyclopedia of Physics, v. 46/2, p. 551-612.

Lieberman, R.J., Shadix, L.C., Newport, B.S., Crout, S.R., Buescher, S.E., Safferman, R.S., Stetler, R.E., Lye, D., Fout, G.S., and Dahling, D.R., 1994, Source water microbial quality of some vulnerable public-groundwater supplies, in Water Quality Technical Conference Proceedings, San Francisco, California, October 1994: American Water Works Association.

MacKenzie, W.R., Hoxie, N.J., Proctor, M.E., Gradus, S., Blair, K.A., Peterson, D.E., Kazmierczak, J.J., Fox, K., Addiss, D. G., Rose, J.B., and Davis, J.P., 1994, Massive waterborne outbreak of Cryptosporidium infection associated with a filtered public water supply, Milwaukee, Wisconsin, March and April, 1993: New England Journal of Medicine, v. 331, no. 3, p. 161-167.
Michel, R.L., 1989, Tritium deposition in the continental United States, 1953-83: U.S. Geological Survey Water-Resources Investigations Report 89-4072, 51 p.

Miller, D.E., Vandike, J.E., and Brookshire, C., 1987, Aquifer classification based on vulnerability to contamina, tion: Rolla, Missouri Department of Natural Resources, Division of Geology and Land Survey, unpublished manuscript, $20 \mathrm{p}$.

Myers, D.N., and Wilde, F.D., eds., 1997, National field manual for the collection of water-quality data-Biological indicators: U.S. Geological Survey Techniques of Water-Resources Investigations, book 9, chap. A7, $38 \mathrm{p}$.

Osmond, J.K., 1971, Uranium and tritium as natural tracers in the Floridan aquifer: Gainesville, Water Resources Research Center, University of Florida, no. 14, 66 p.

Plummer, L.N., Michel, R.L., Thurman, E.M., and Glynn, P.D.,1993, Environmental tracers for age dating young ground water, in Alley, W.M., ed., Regional groundwater quality: Van Nostrand Reinhold, New York, p. 255-294.

Reynolds, K.A., Gerba, C.P., and Pepper, I.L., 1996, Detection of infectious enteroviruses by an integrated cell culture-PCR method: Applied Environmental Microbiology, v. 62, no. 4, p. 1,424-1,427.

Science Applications International Corporation, 1998, Viral breakthroughs in drinking water wells: McLean, Virginia, Science Applications International Corporation, draft report, $128 \mathrm{p}$.

Slack, L.J., and Oakley, W.T., 1989, Tritium analyses of shallow ground water in Mississippi, April 1989: U.S. Geological Survey Open-File Report 89-418, 8 p.

Slack, L.J., and Oakley, W. T., 1991, Tritium in ground water in Mississippi, 1989-90: U.S. Geological Survey Open-File Report 91-177, 12 p.

Slack, L.J., and Oakley, W.T., 1992, Tritium analyses of water in the Mississippi River alluvial aquifer in northwestern Mississippi, August 1991: U.S. Geological Survey Open-File Report 92-75, 9 p.

Swerdlow, D.L., Woodruff, B.A., Brady, R.C., Griffin, P.M., Tippen, S., Donnell, H.D., Geldreich, E.E., Payne, B.J., Meyer, A., Wells, J.G., Greene, K.D., Bright, M., Bean, N.H., and Blake, P.A., 1992, A waterborne outbreak in Missouri of Escherichia coli 0157:H7 associated with bloody diarrhea and death: Annals of Internal Medicine, v. 117 , no. 10 , p. 812-819.

Thatcher, L.L., 1962, The distribution of tritium fallout in precipitation over North America: International Association of Science Hydrology Bulletin, vol. 7, no. 2, p. 48.

Thatcher, L.L., Janzer, V.J., and Edwards, K.W., 1977, Methods for determination of radioactive substances in water and fluvial sediments: U.S. Geological Survey . Techniques of Water-Resources Investigations, book 5, chap. A5, 95 p. 
University of Missouri, 1998, Missouri county population estimates and components of change: Office of Social and Economic Data Analysis, Missouri State Census Data Center Program, 6 p. http://www.oseda.missouri.edu/mscdc/popests/mopop97.html.

U.S. Environmental Protection Agency, 1988, Maximum contaminant levels (subpart 13 of 141, National revised drinking-water regulations): U.S. Code of Federal Regulations, Title 40 , parts 100 to 149 , revised as of July 1, 1988, p. 530-533.

1995a, Information Collection Requirements rule-Protozoa and enteric virus sample collection procedures: Washington, D.C., Office of Ground Water and Drinking Water, EPA/814-B-95-001, $63 \mathrm{p}$.

1995b, Virus monitoring protocol for the Information Collection Requirements rule: Washington, D.C.,
Office of Ground Water and Drinking Water, EPA/ 814-B-95-002, $25 \mathrm{p}$. and appendices.

1996, ICR Microbial Laboratory Manual: Washington, D.C., Office of Research and Development, EPA/ 600/R-95/178, 132 p. and appendices.

2000 , National primary drinking water regulations-Ground water rule (proposed rules): U.S. Code of Federal Regulations, Title 40, parts 141 and 142, p. 30,194-30,274.

U.S. Geological Survey, 1990, Land use and land cover digital data from 1:250,000- and 1:100,000-scale maps: U.S. Geodata Users Guide 4, 33 p.

Wilde, F.D., and Radtke, D.B., eds., 1998, National field manual for the collection of water-quality data-Field measurements: U.S. Geological Survey Techniques of Water-Resources Investigations, book 9, chap. A6, $238 \mathrm{p}$. 
TABLES 


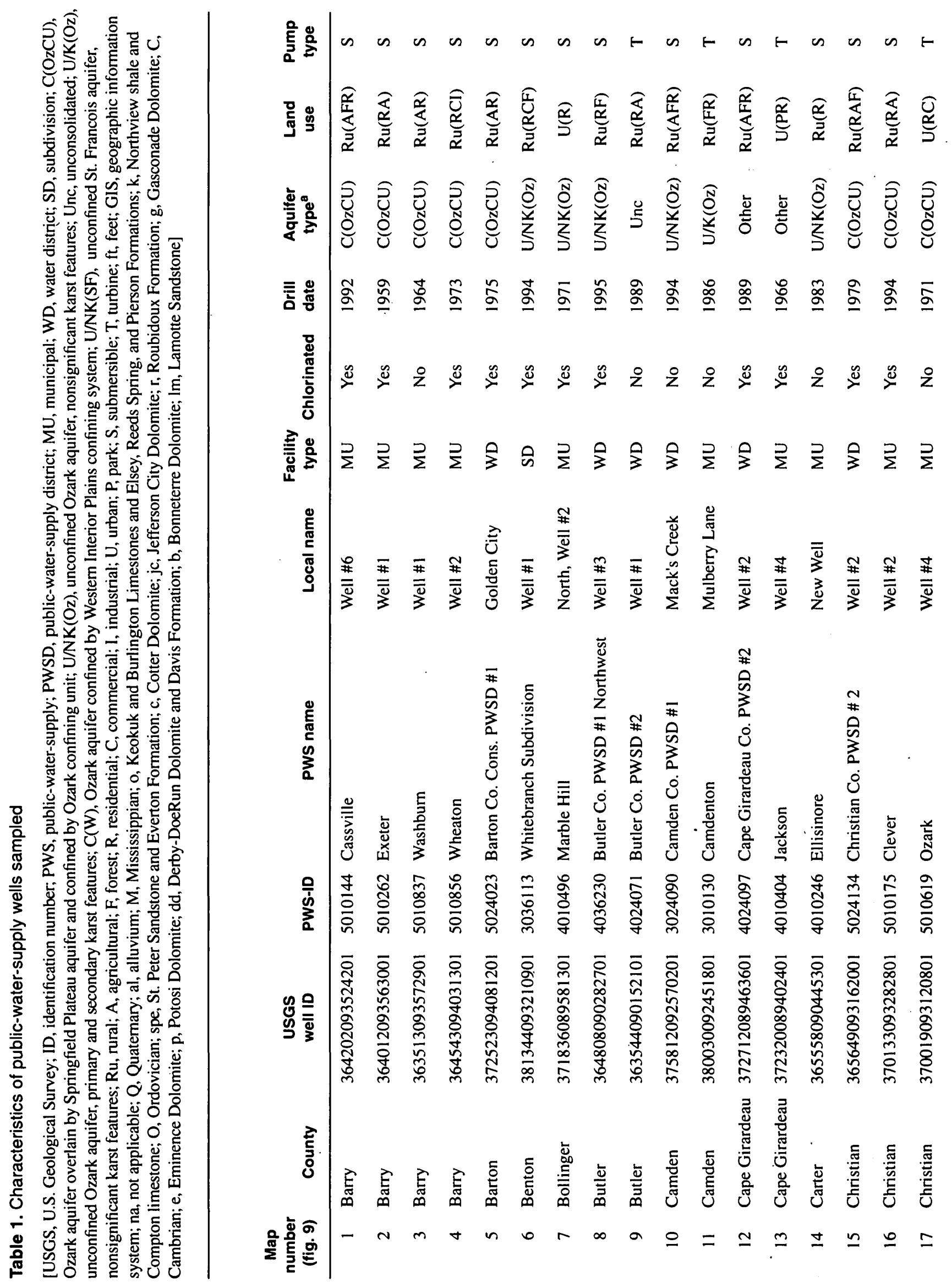


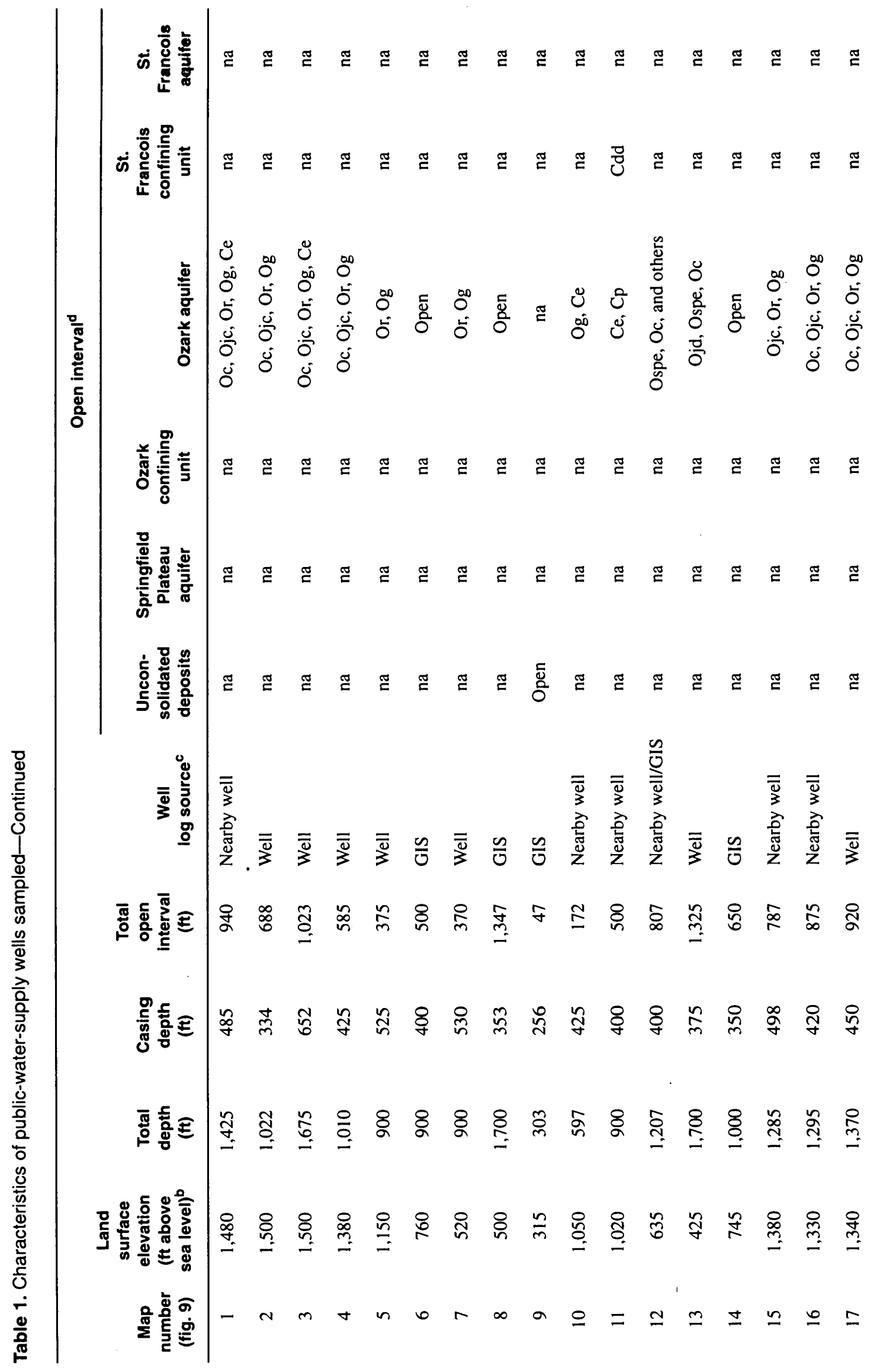




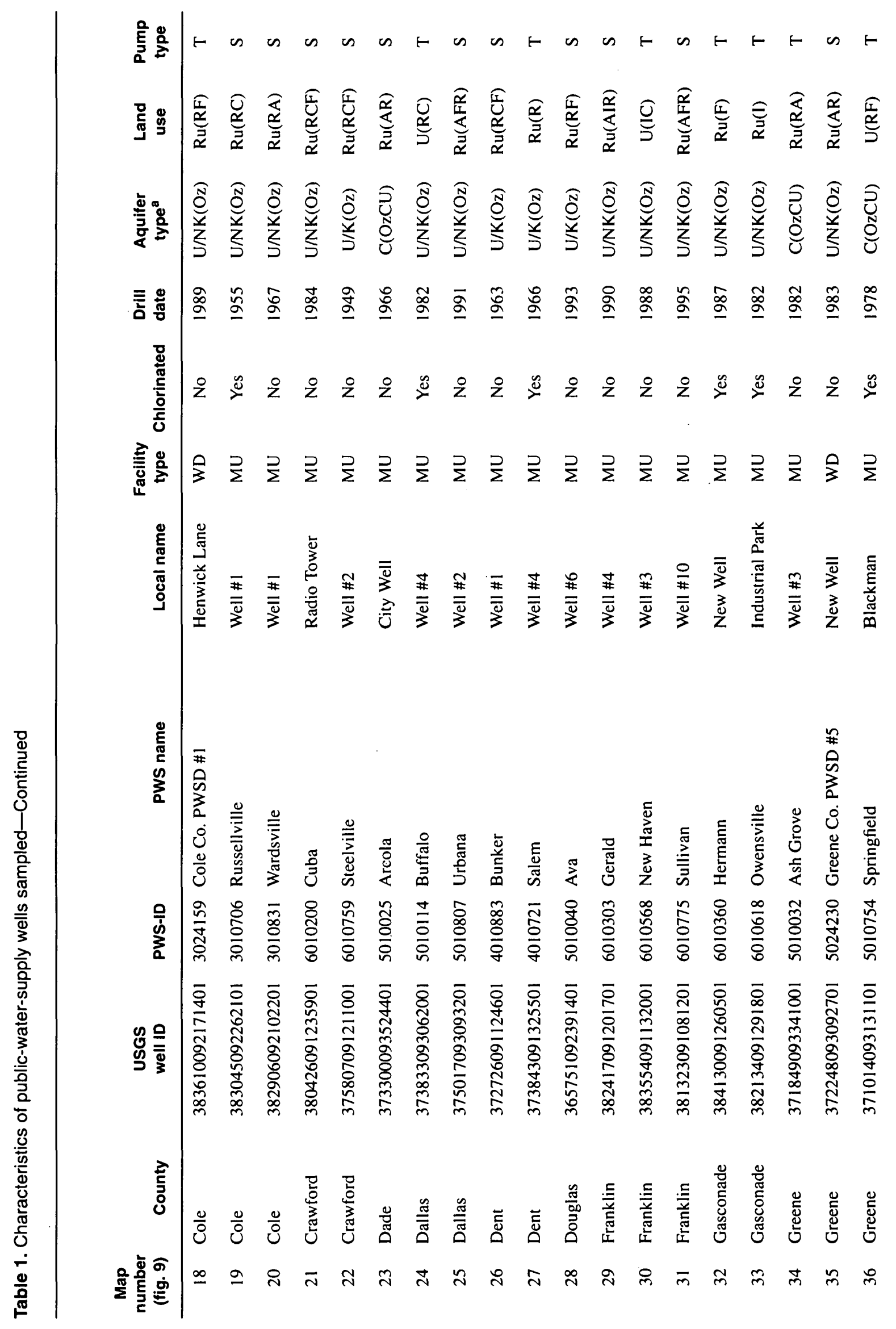




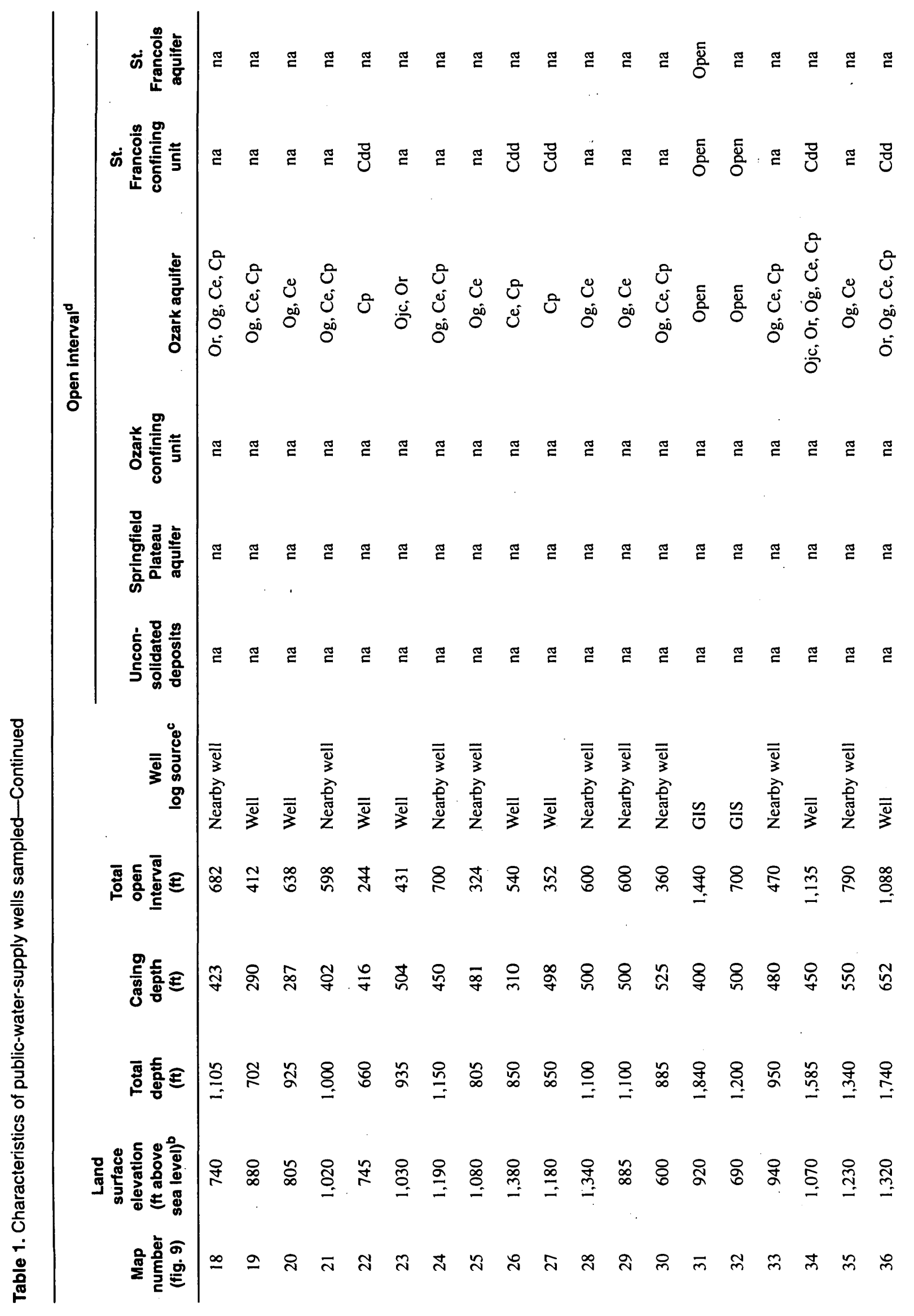




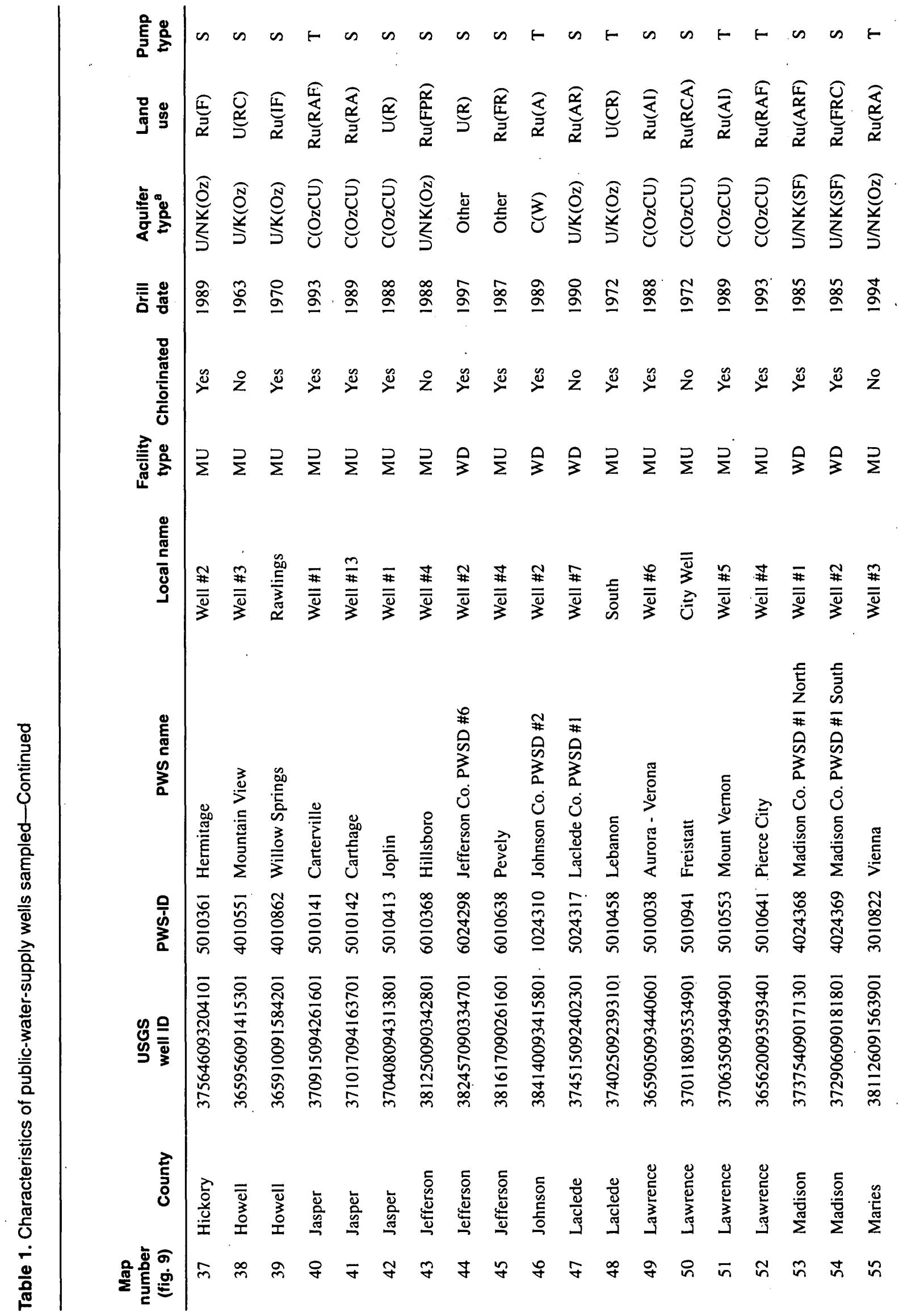




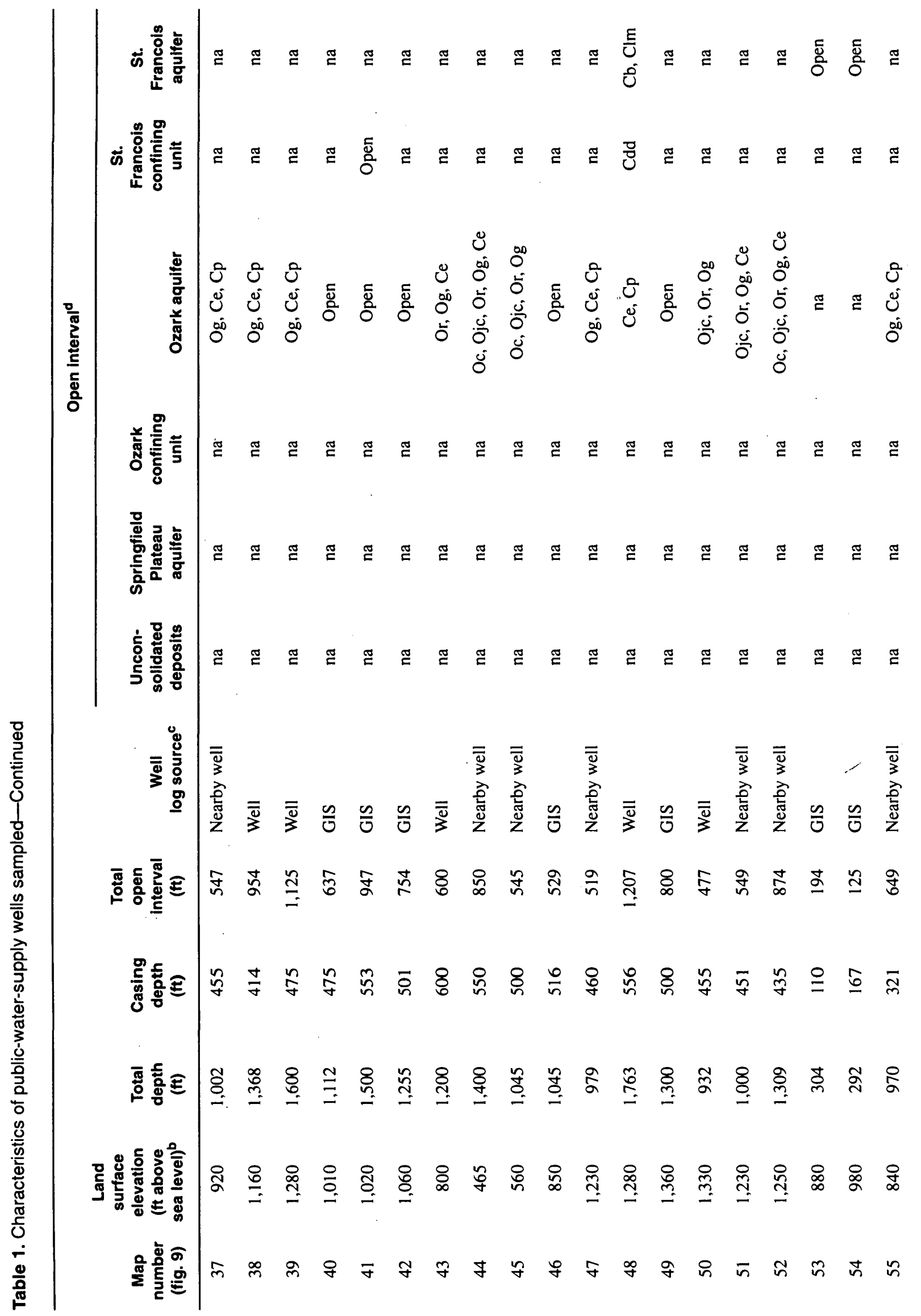




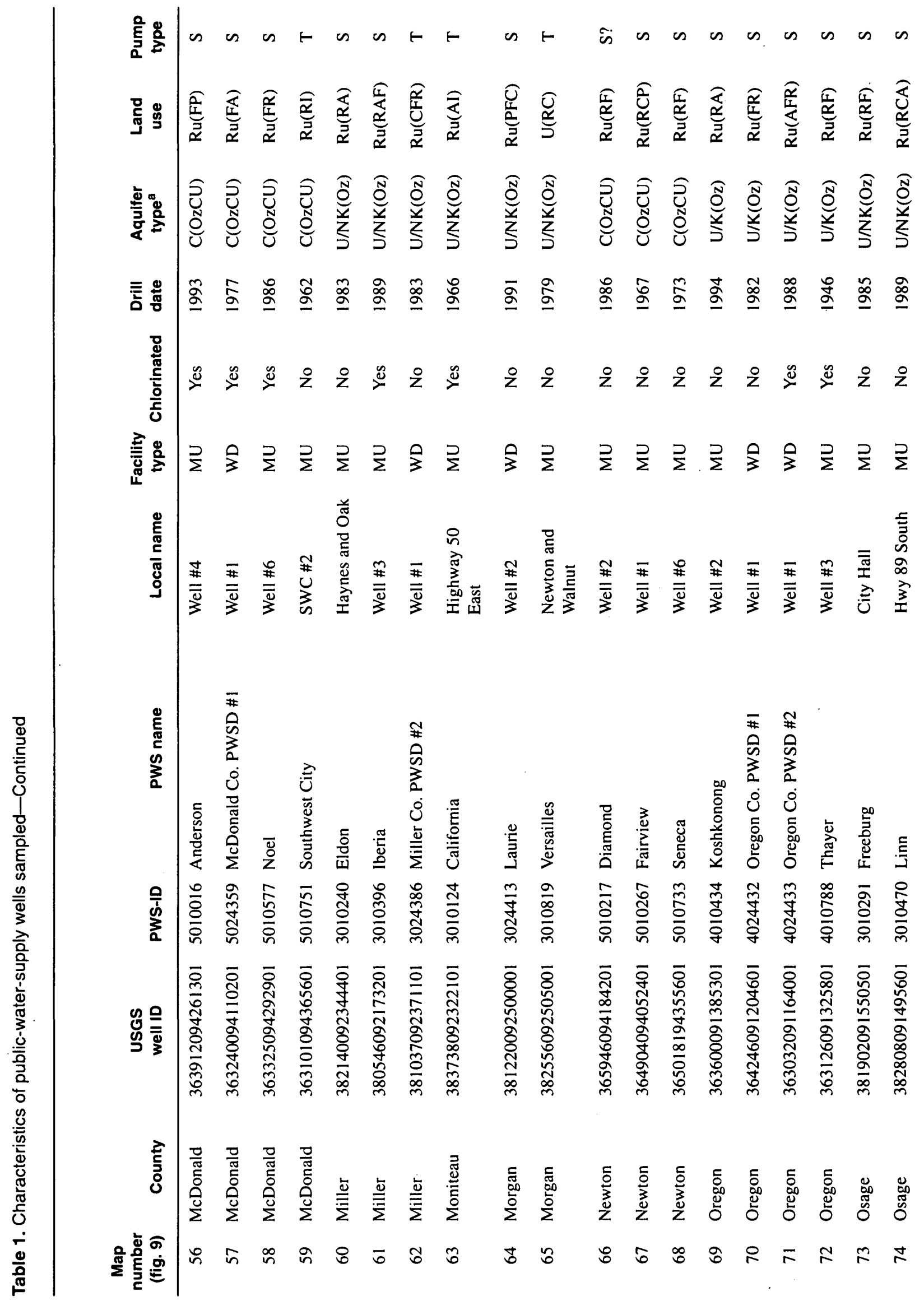




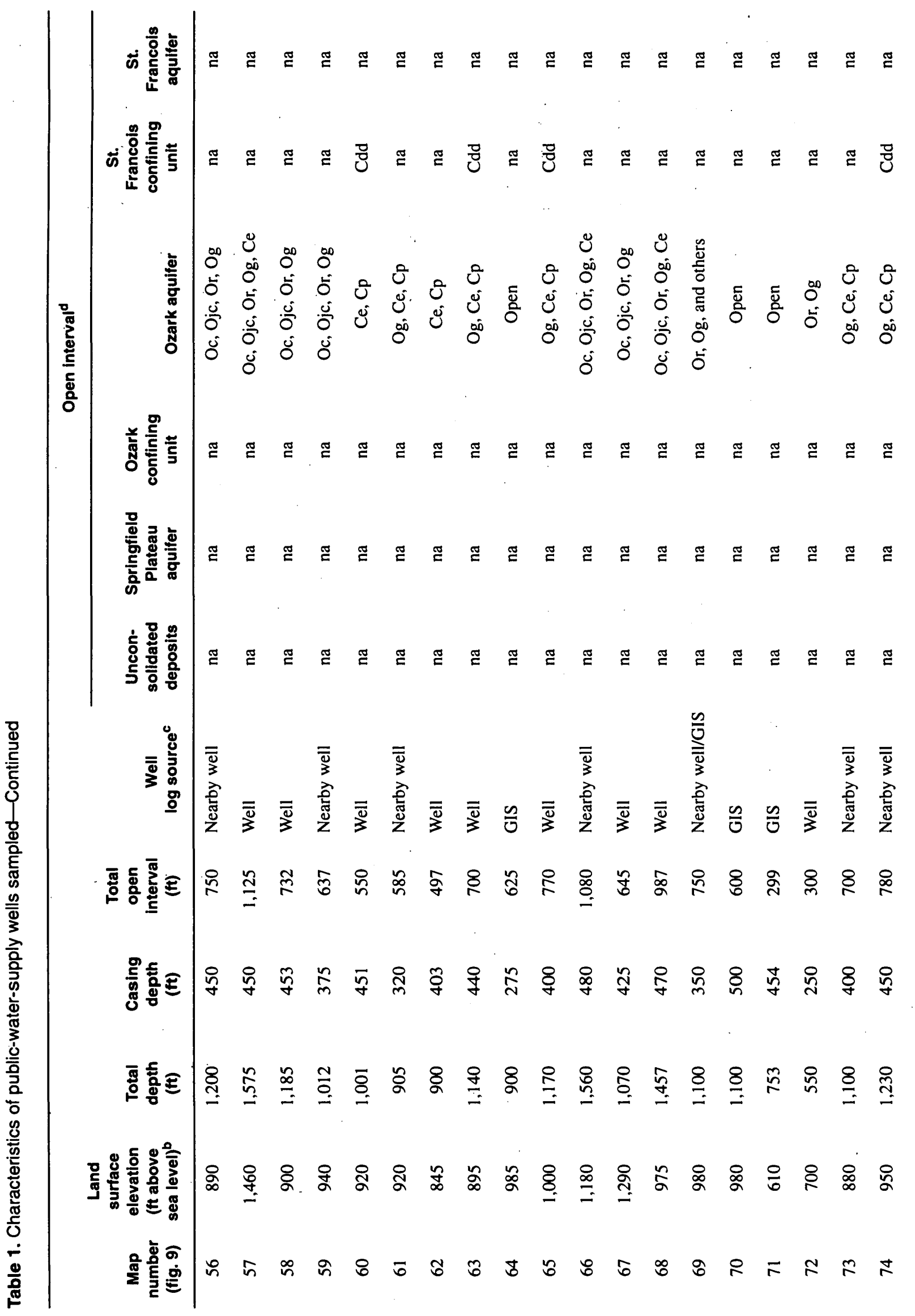




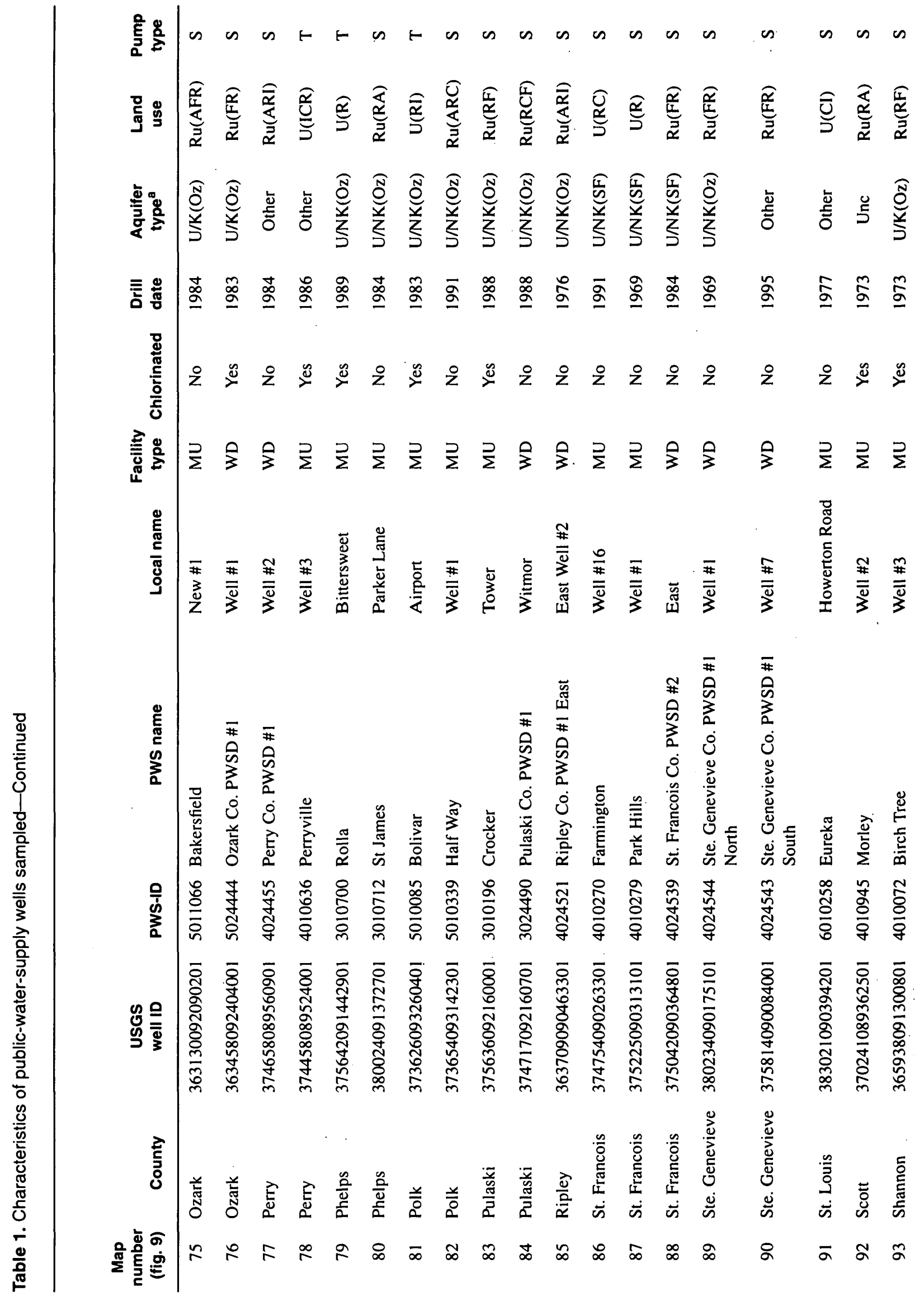




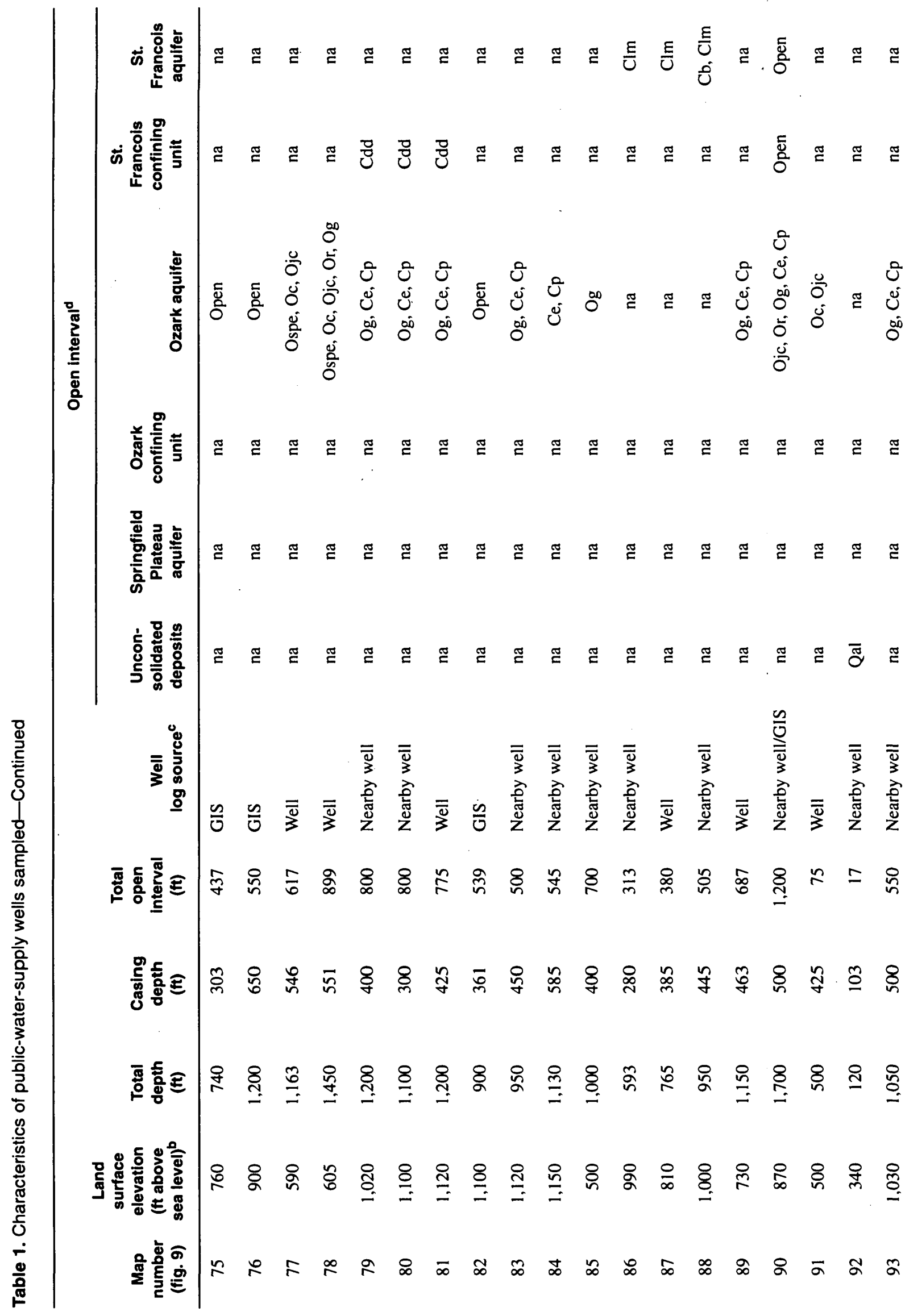




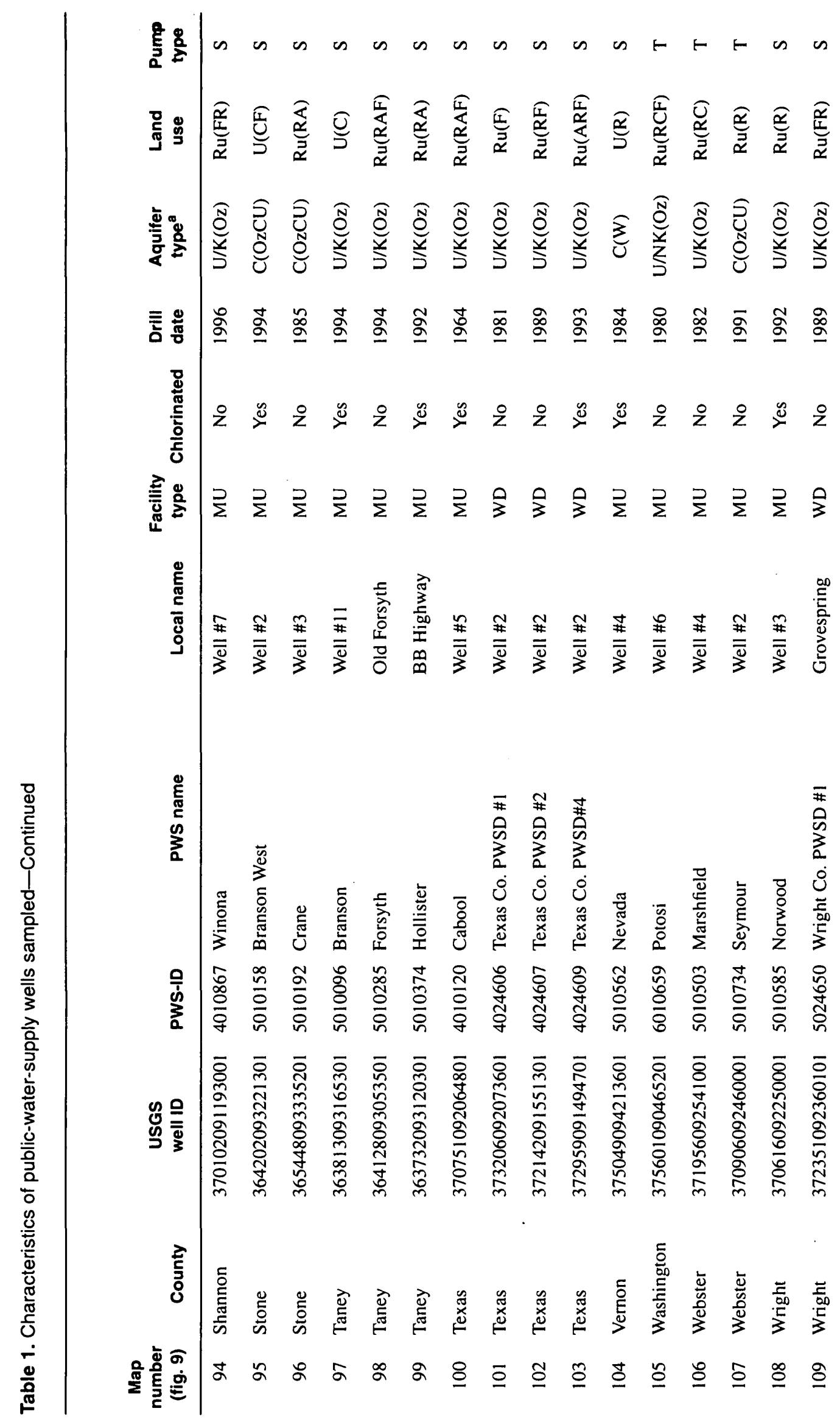




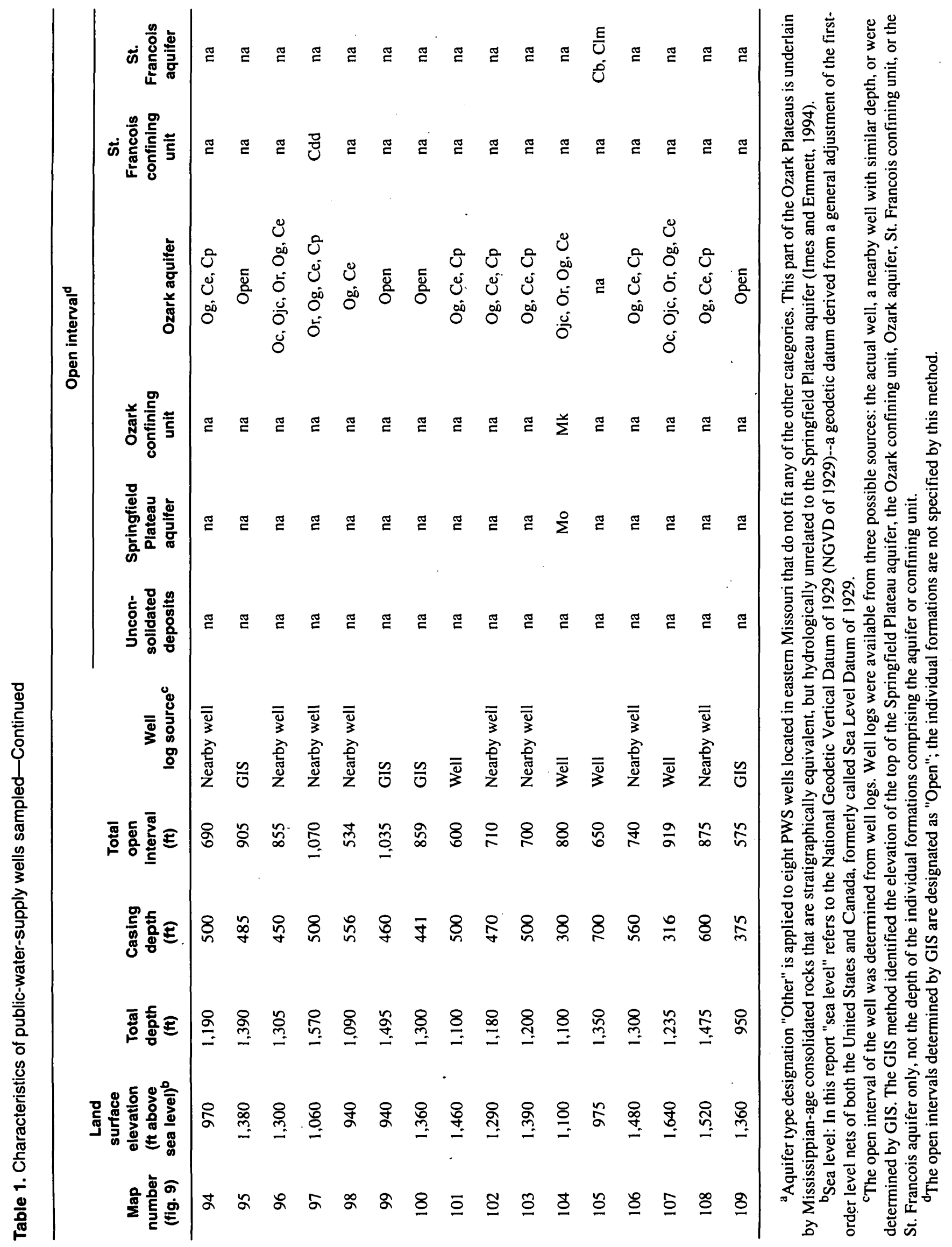




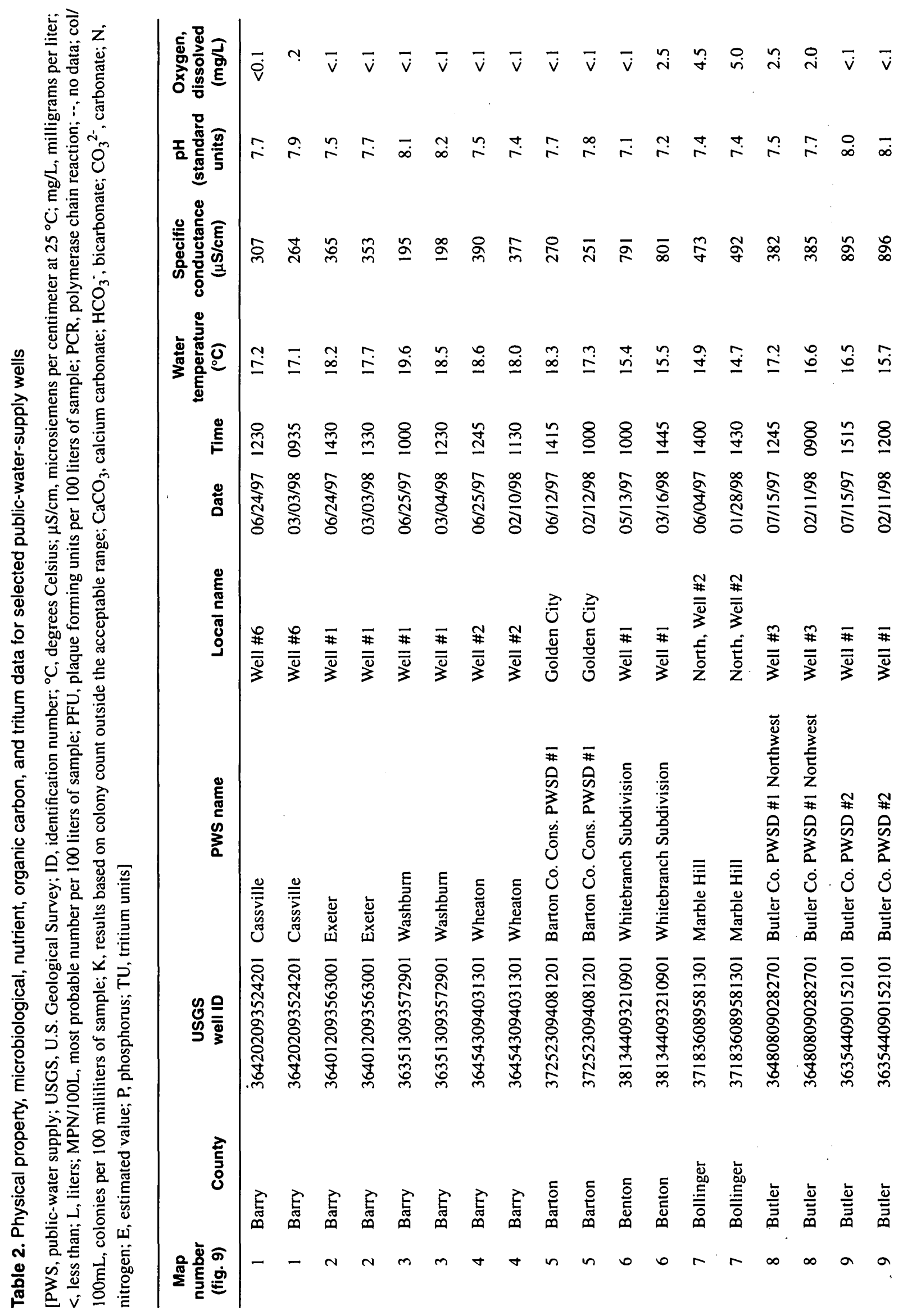




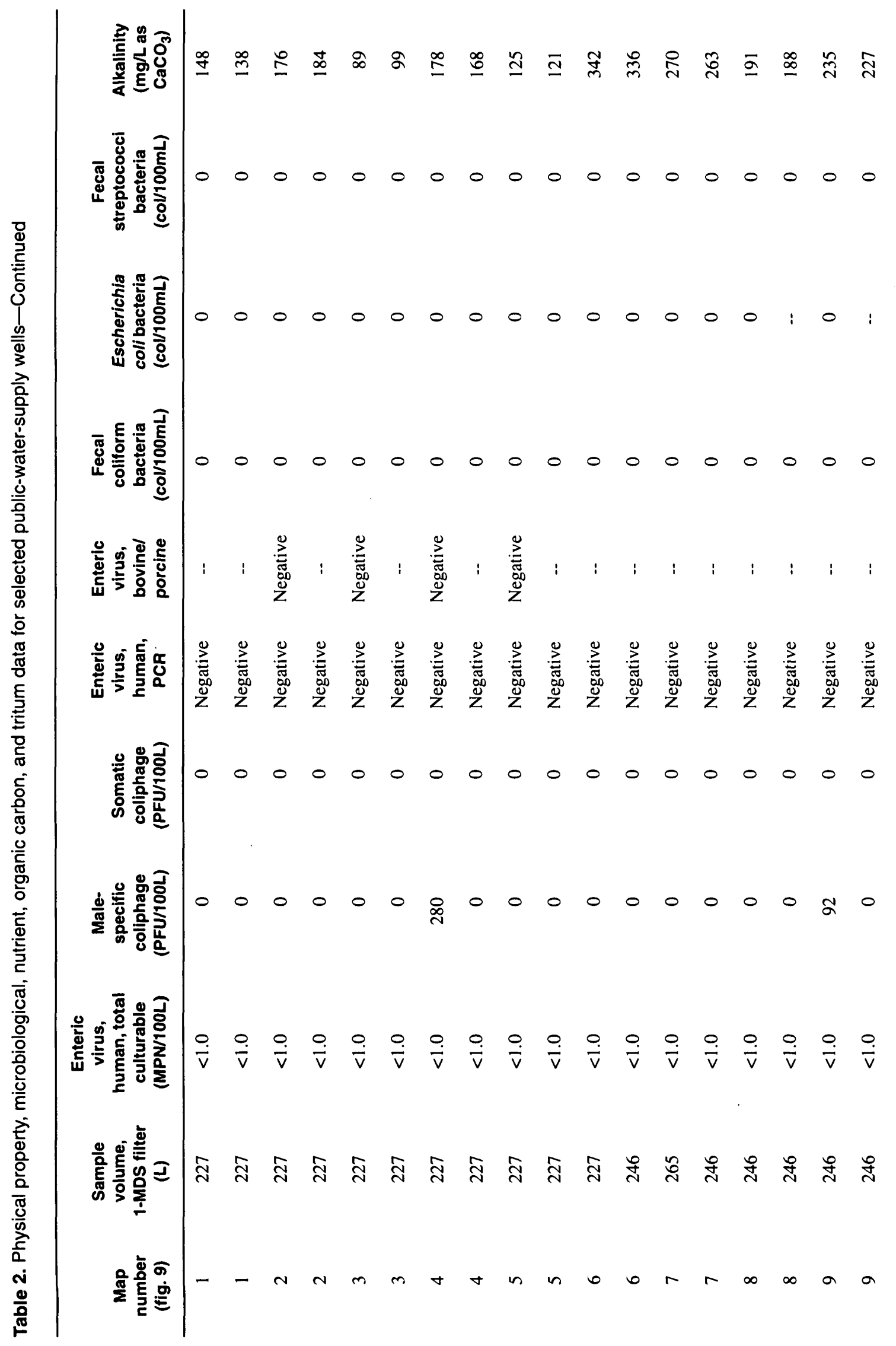




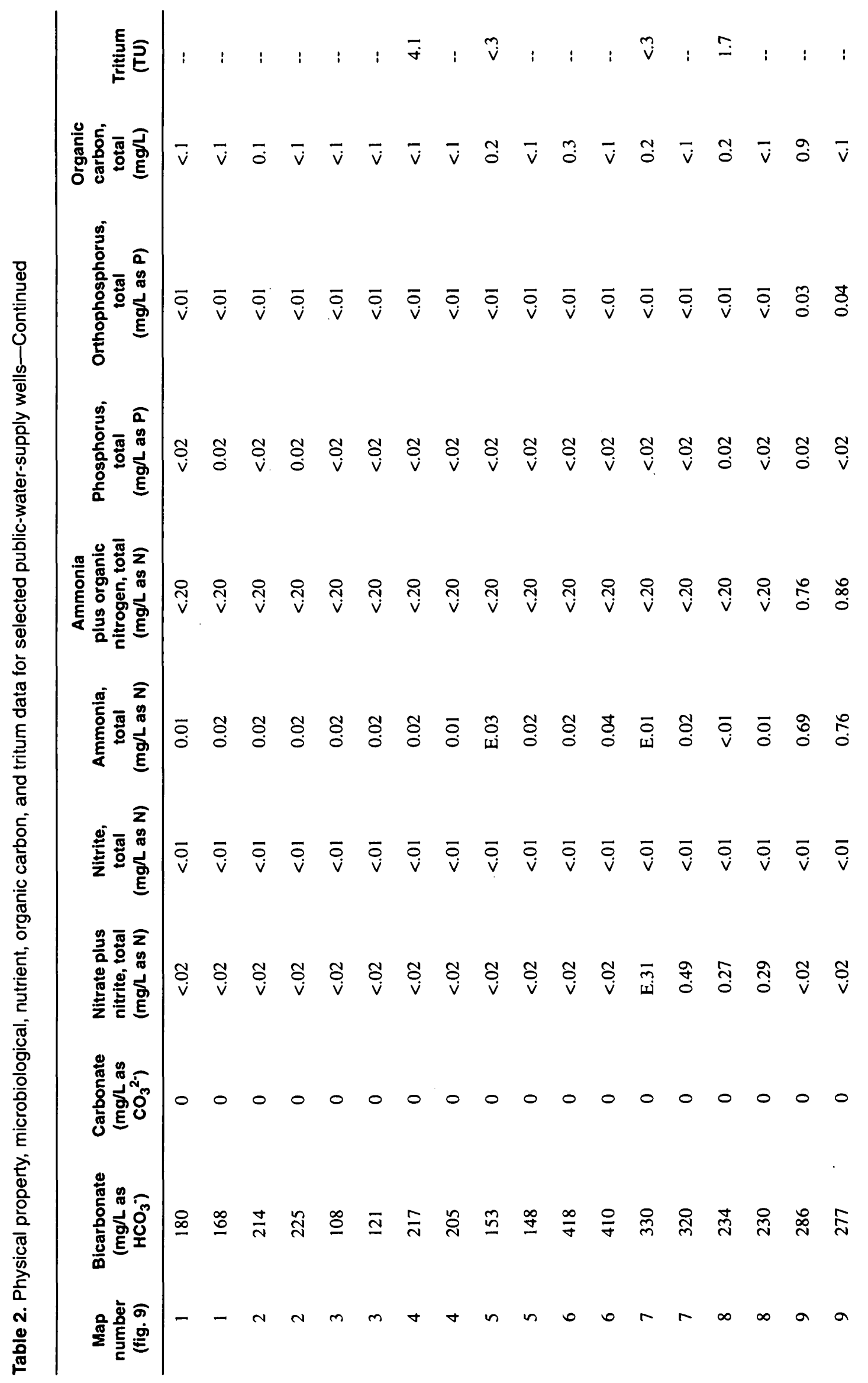




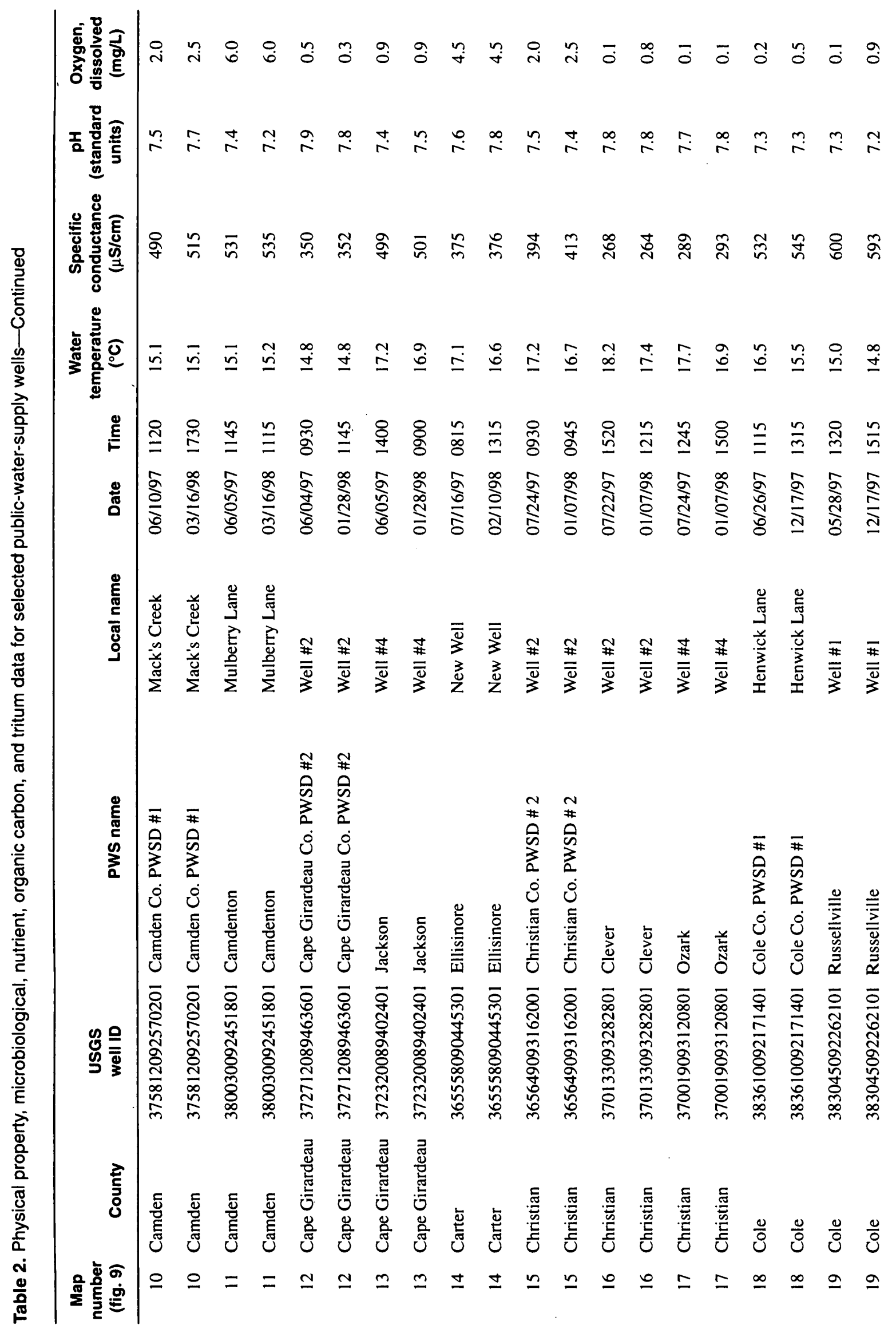




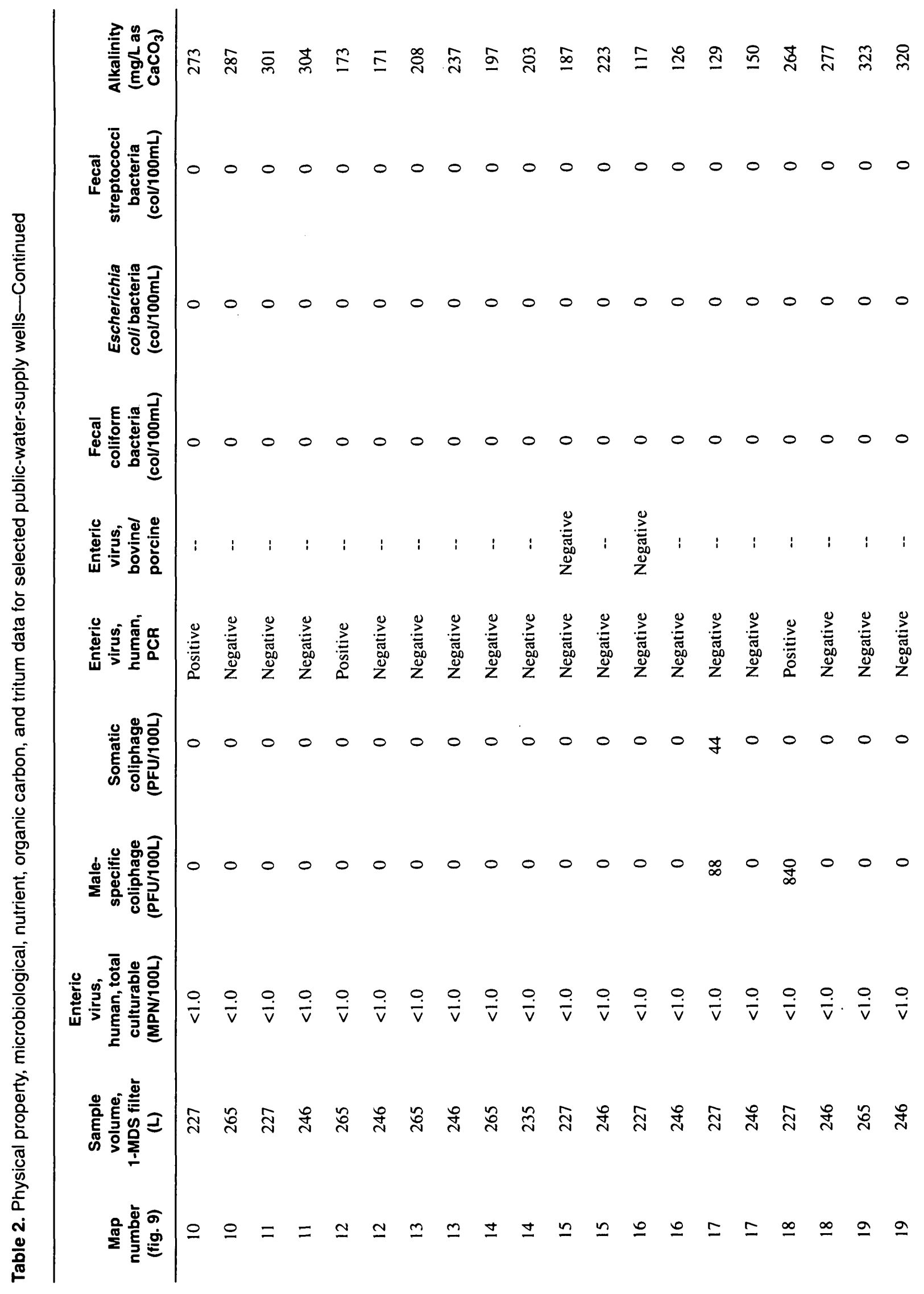




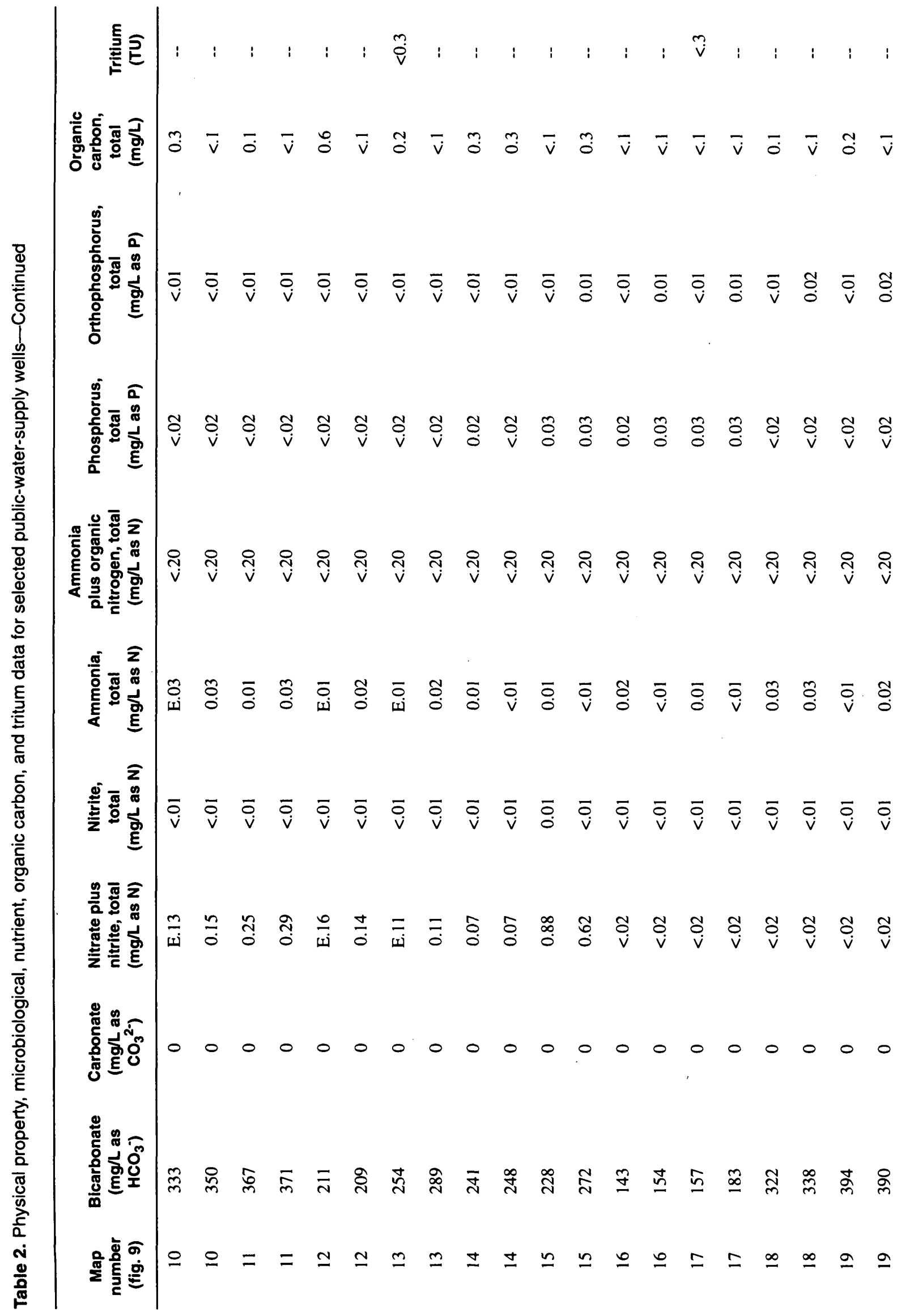




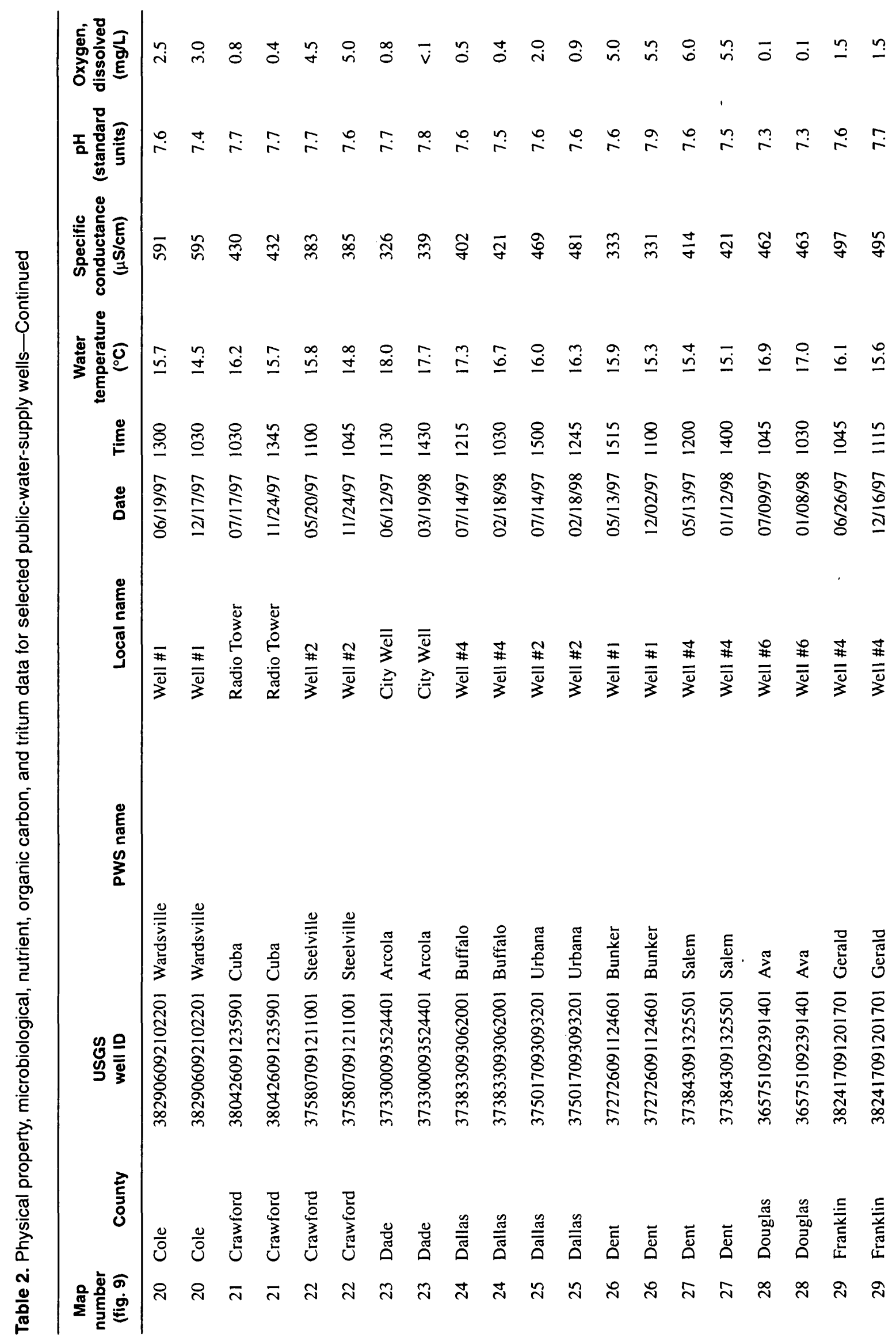




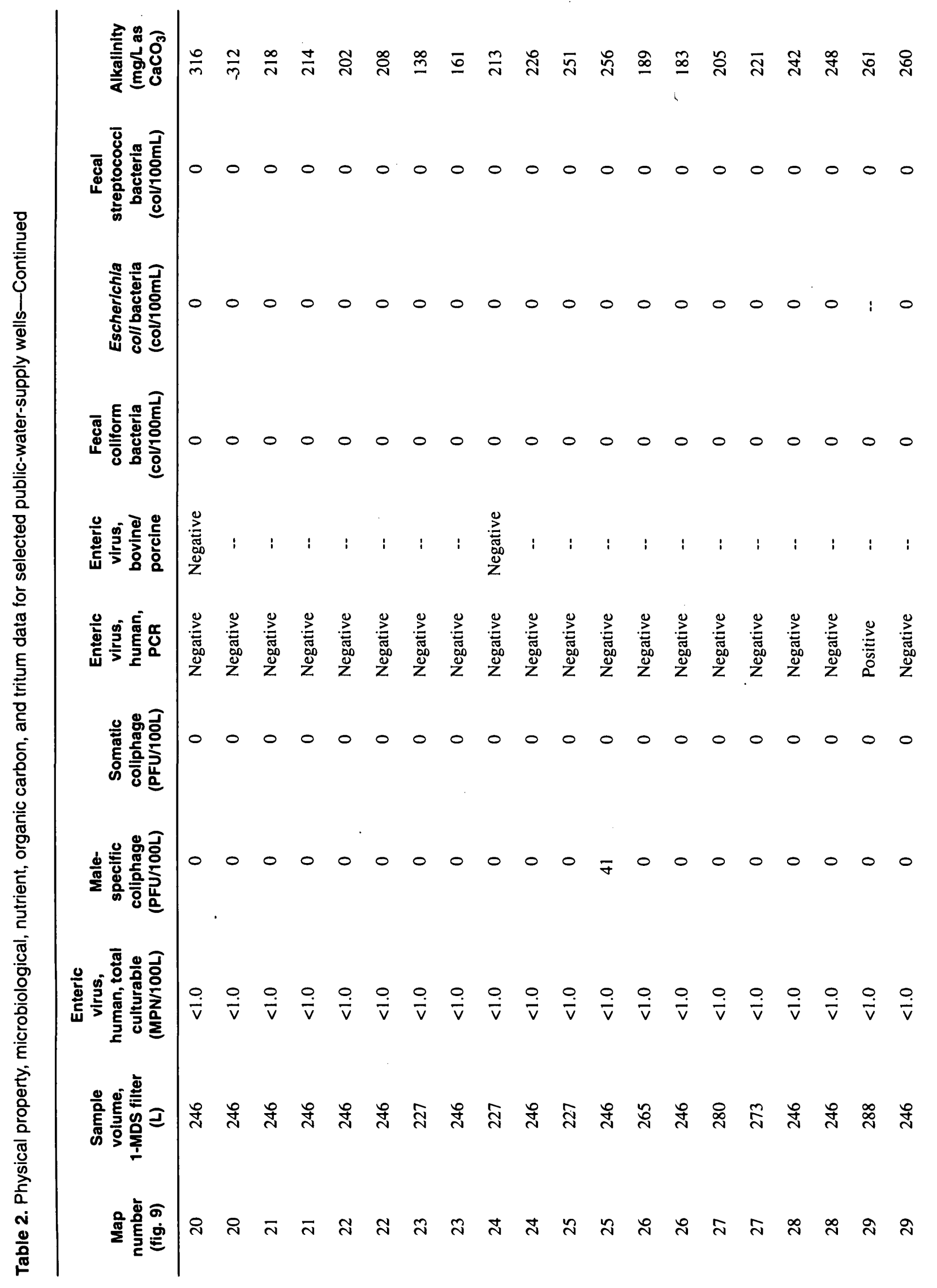




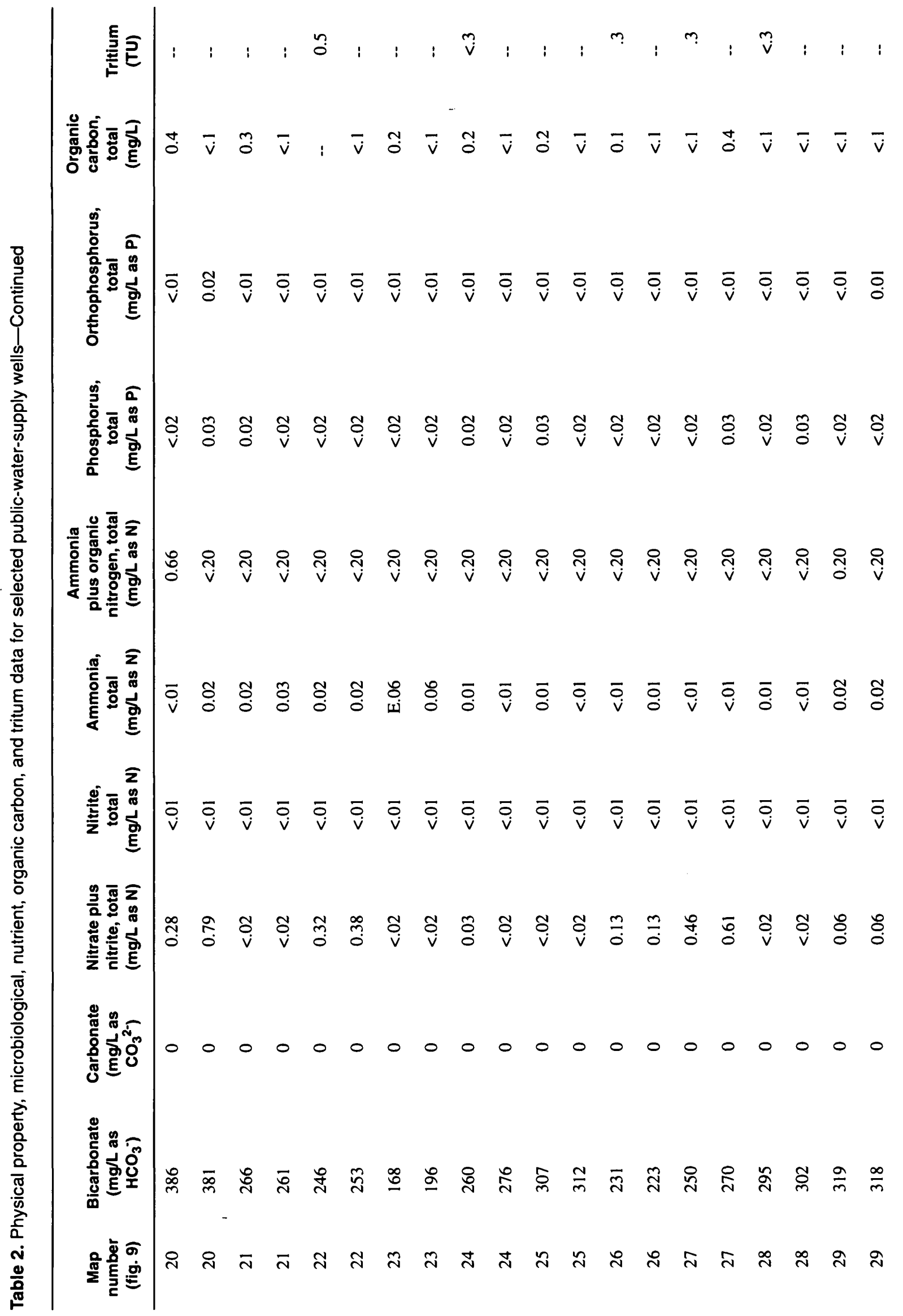




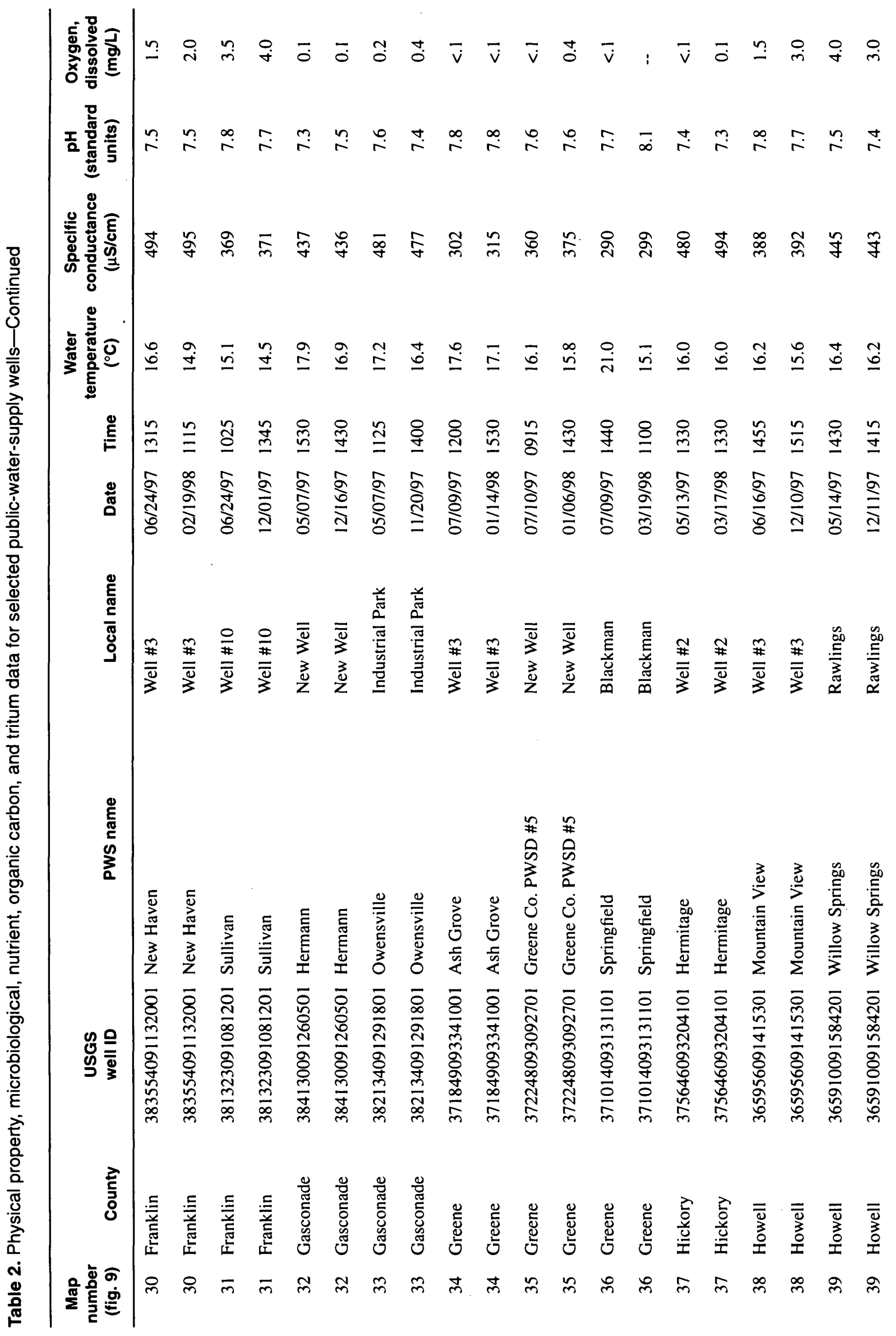




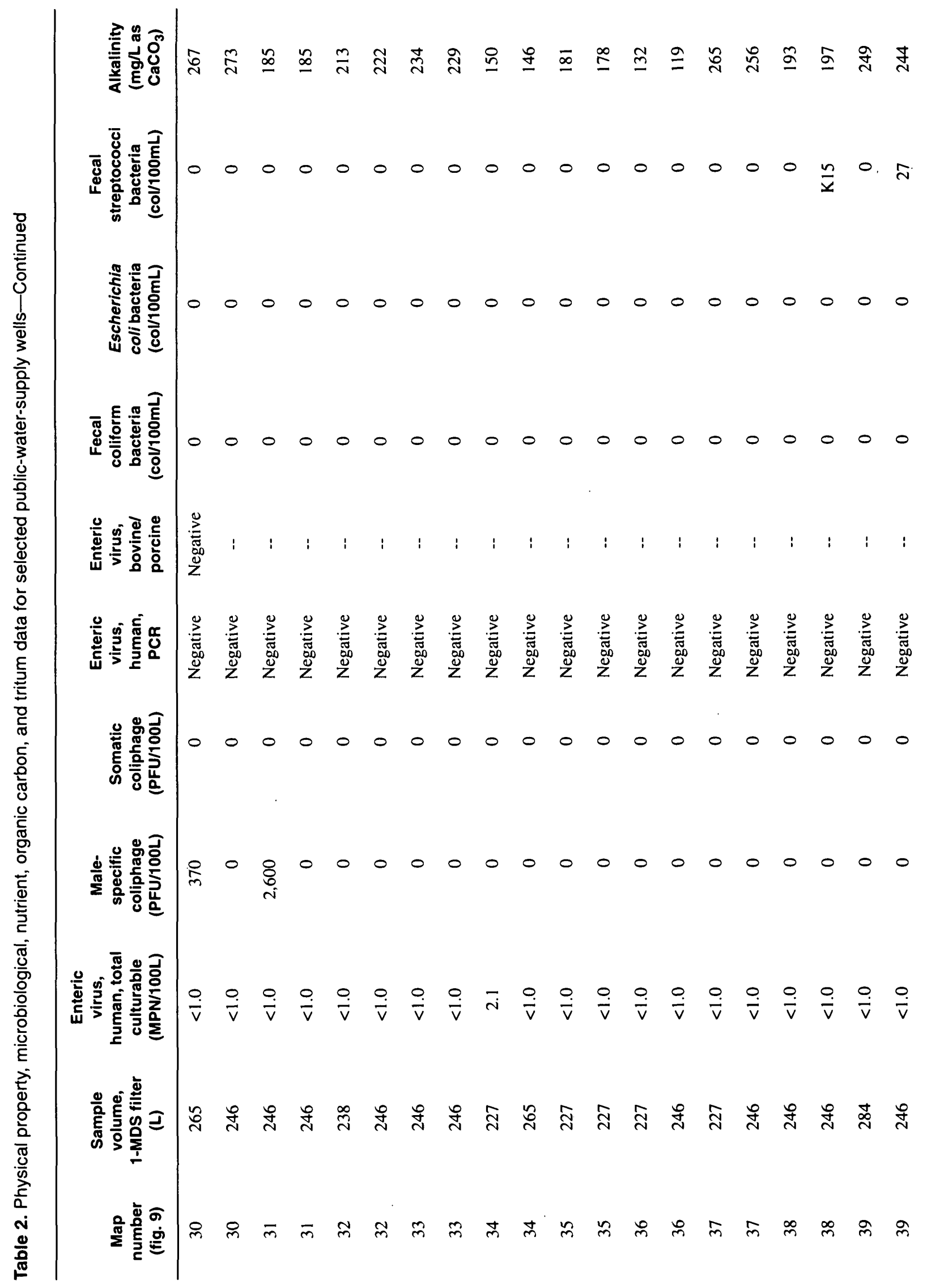




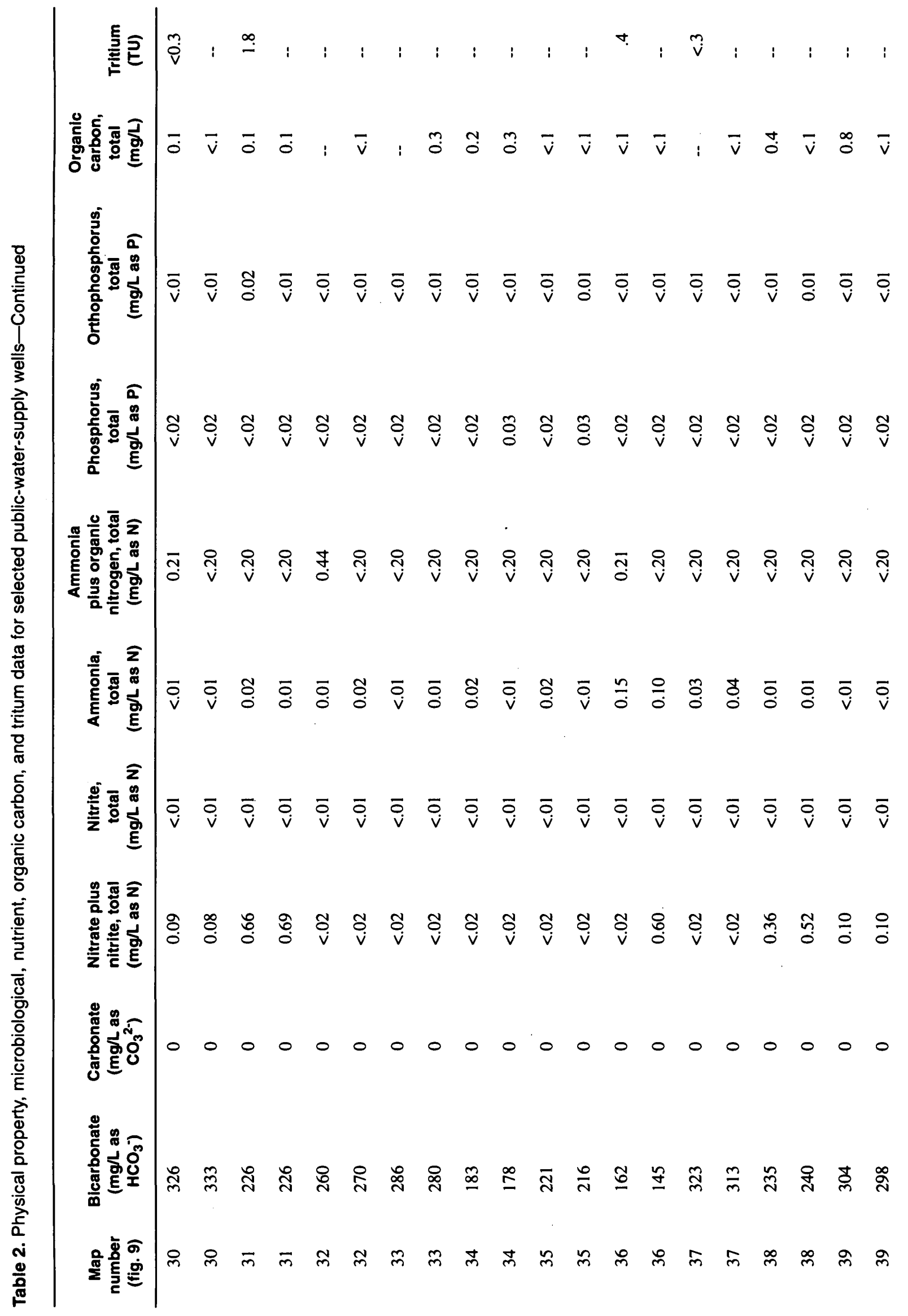




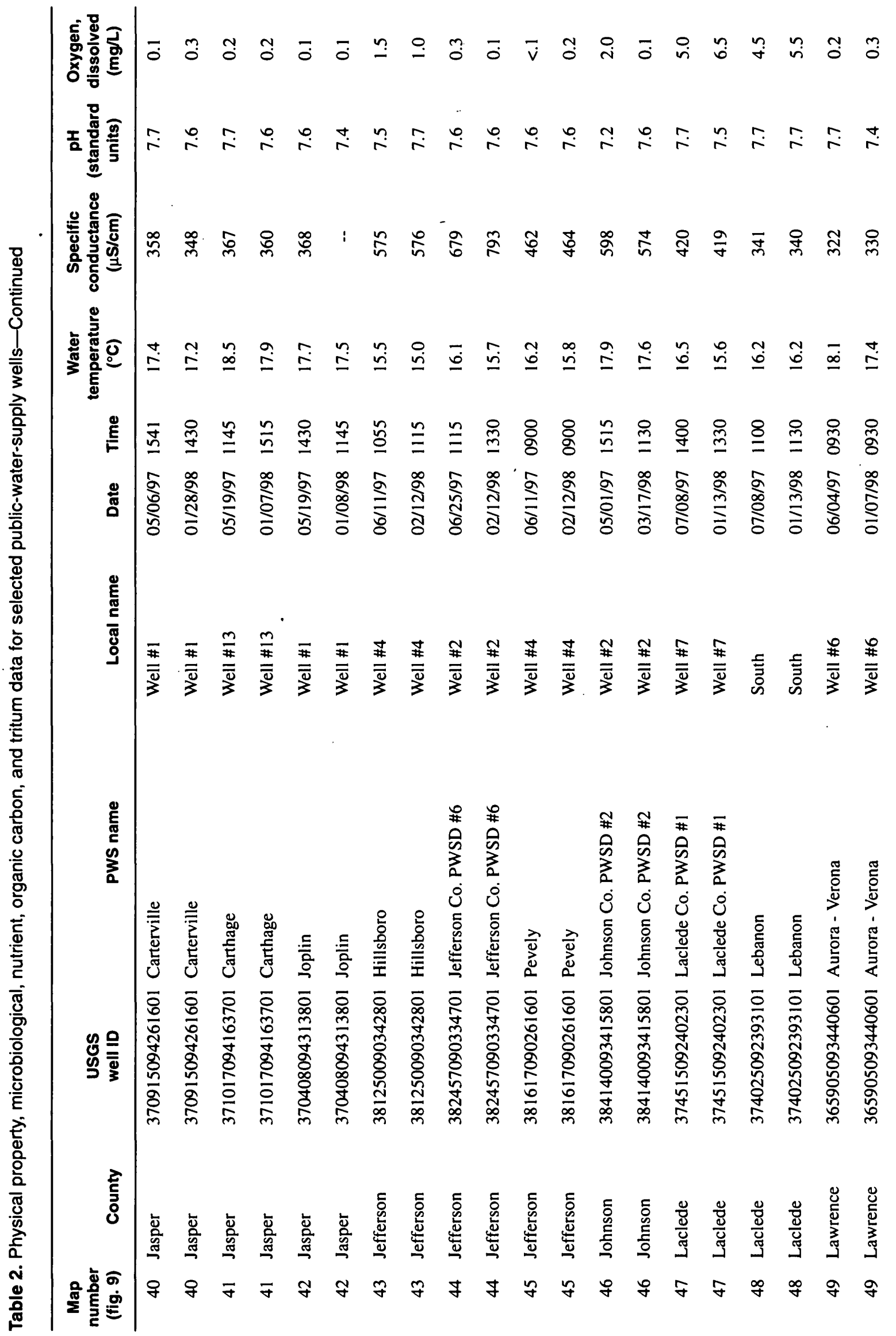

Physical Property, Microbioogical, Nutrient, Organic Carbon, and Tritum Data for Selected Pubilc-Water-Supply-Wells 


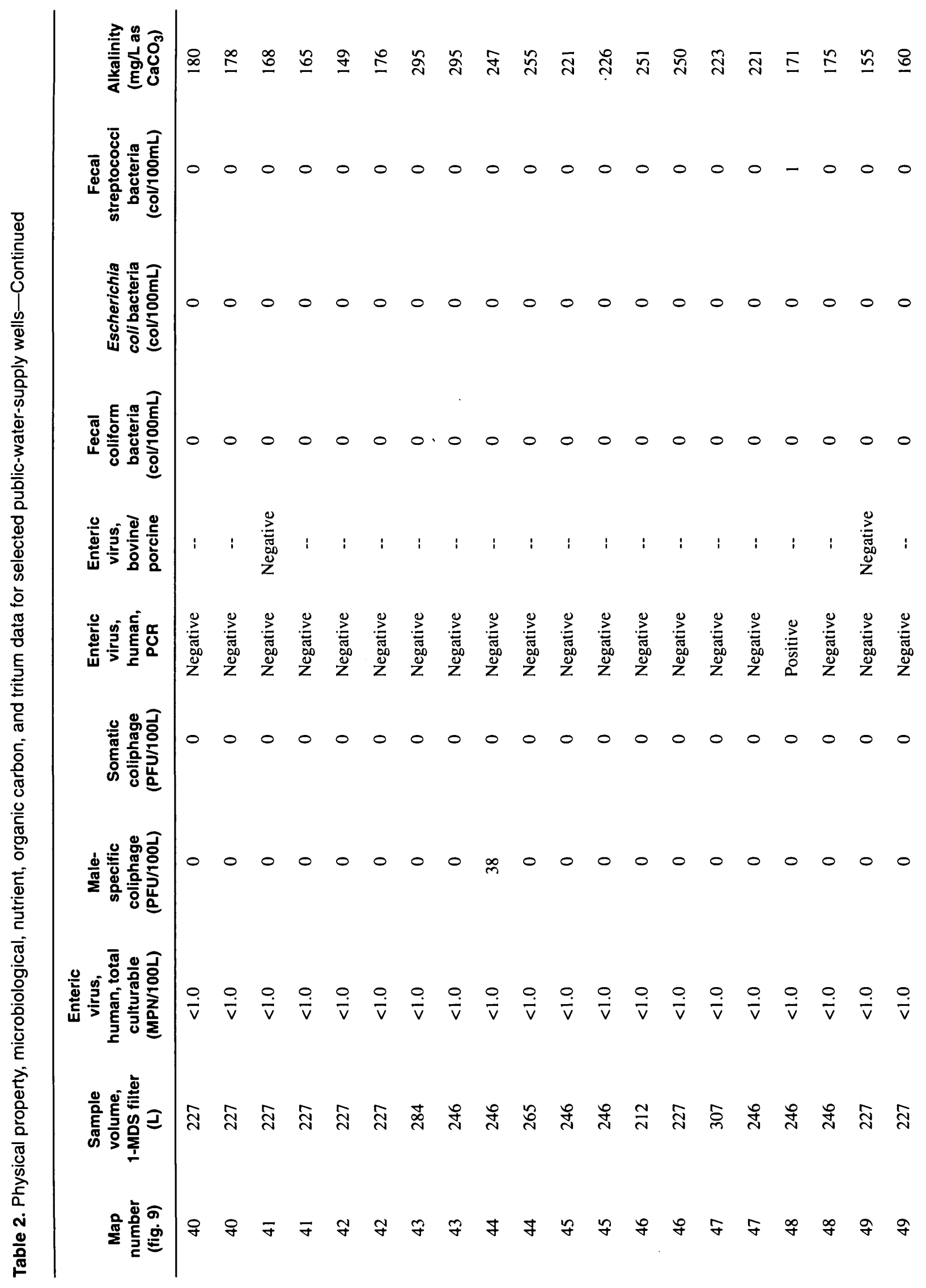




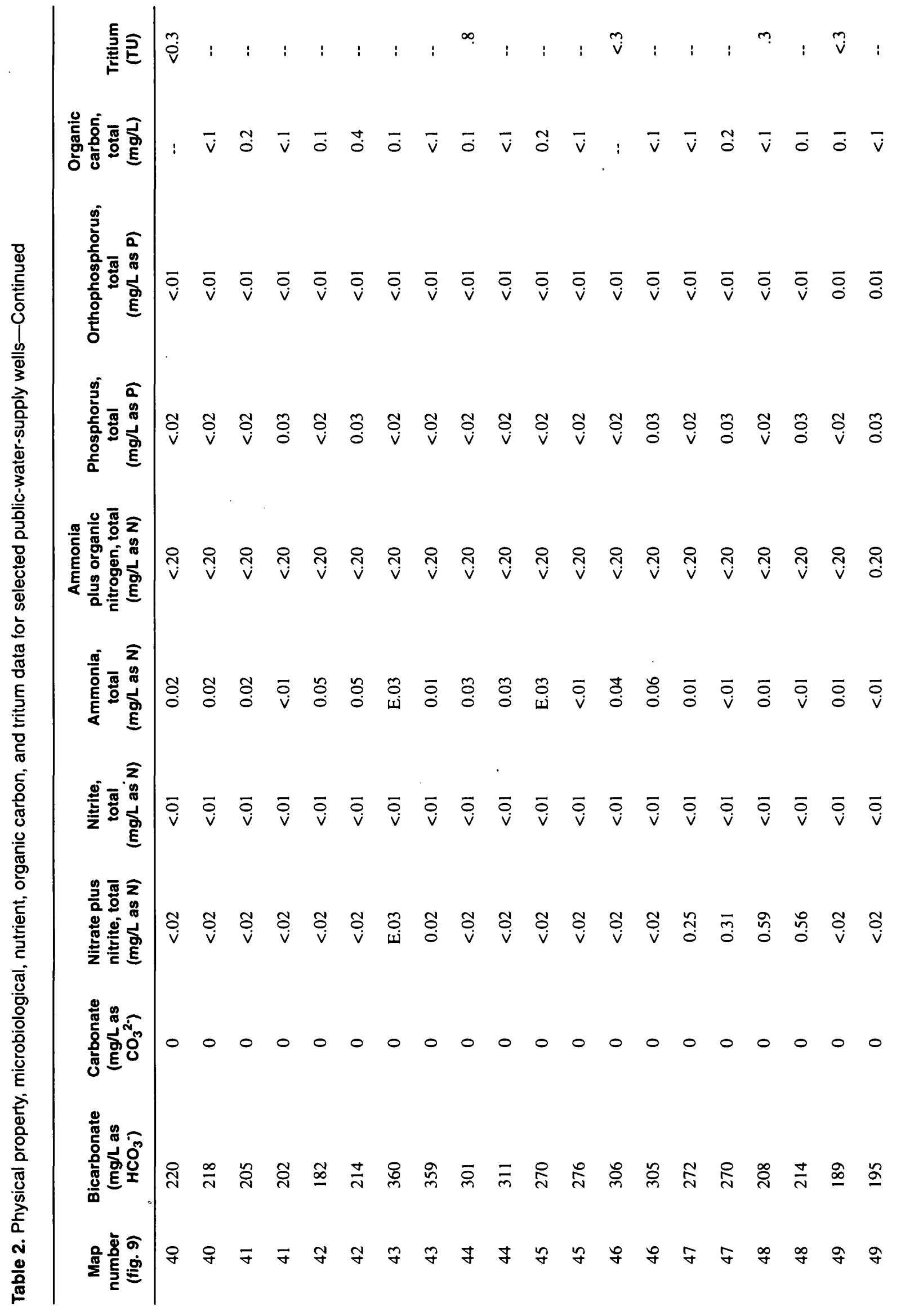




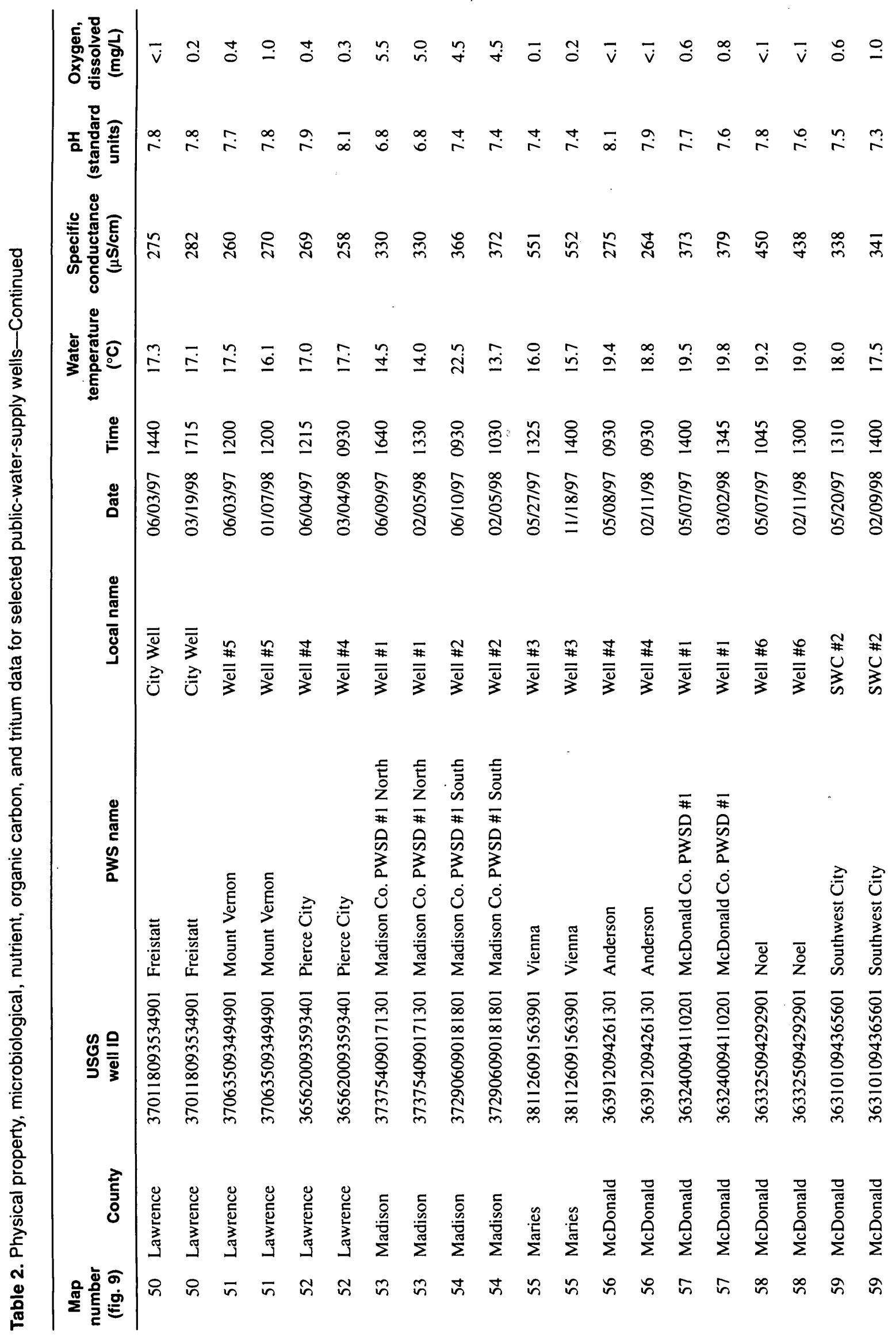




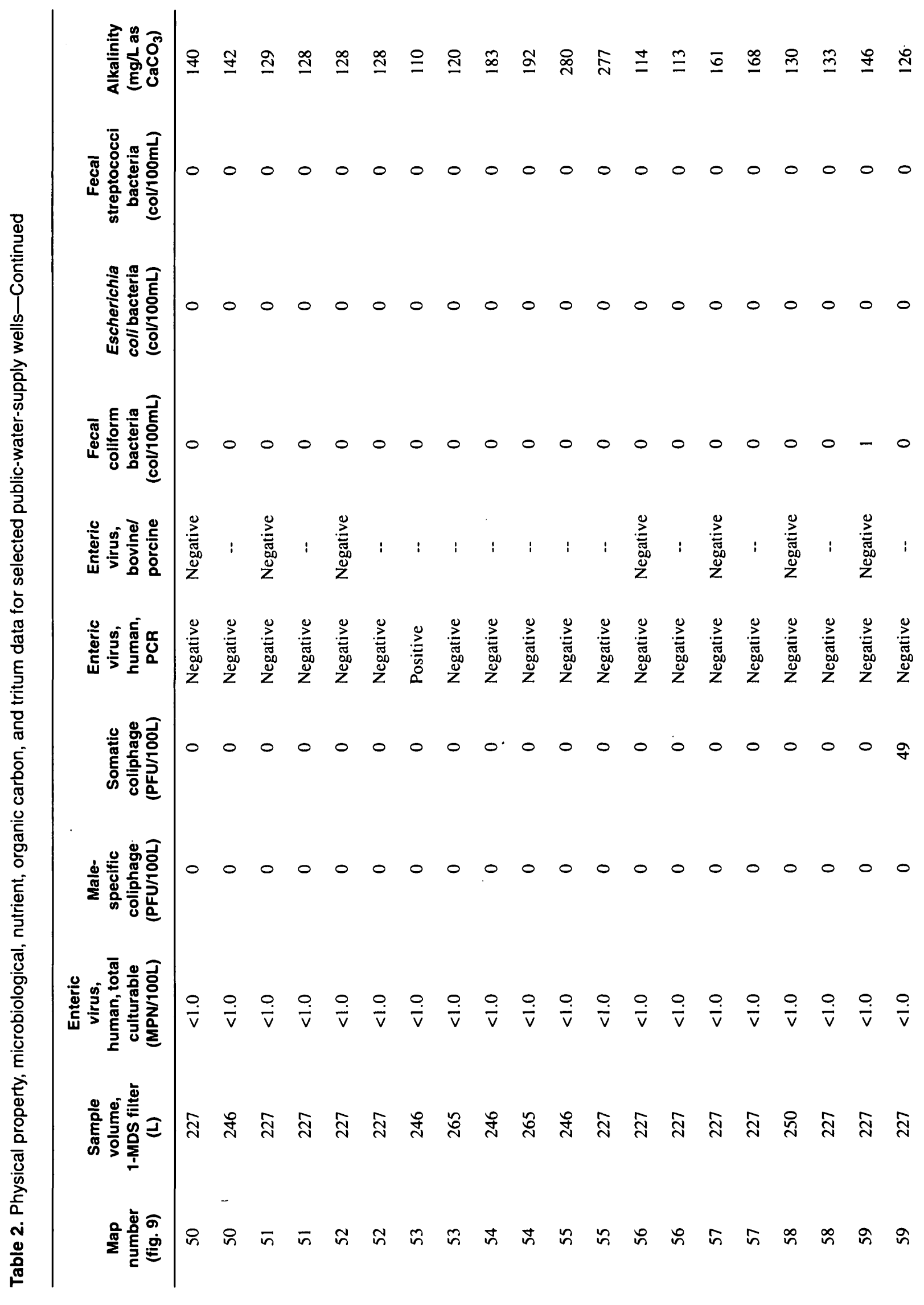

Physical Property, Microbloogical, Nutrient, Organic Carbon, and Tritum Data for Selected Public-Water-Supply-Wells 


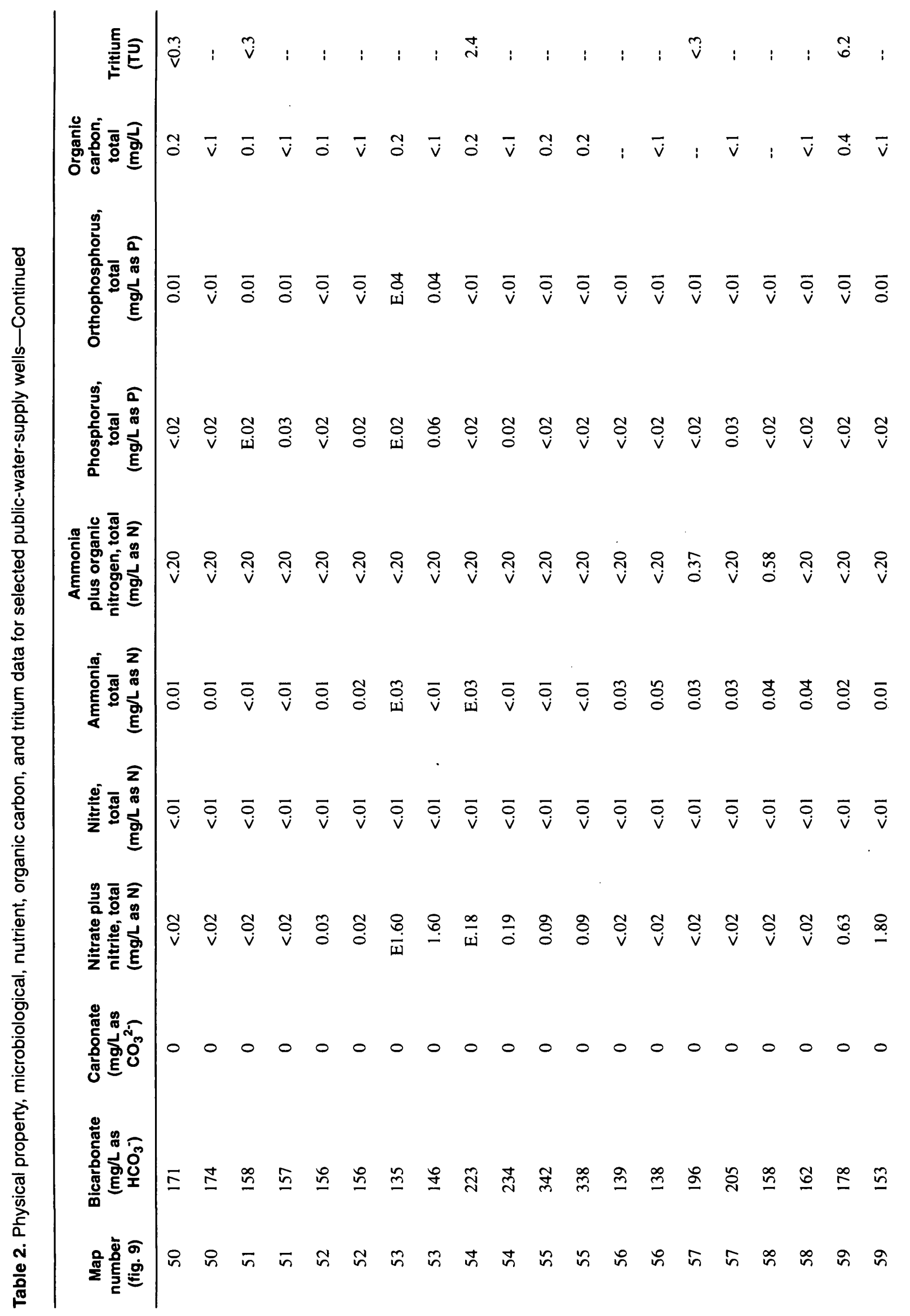




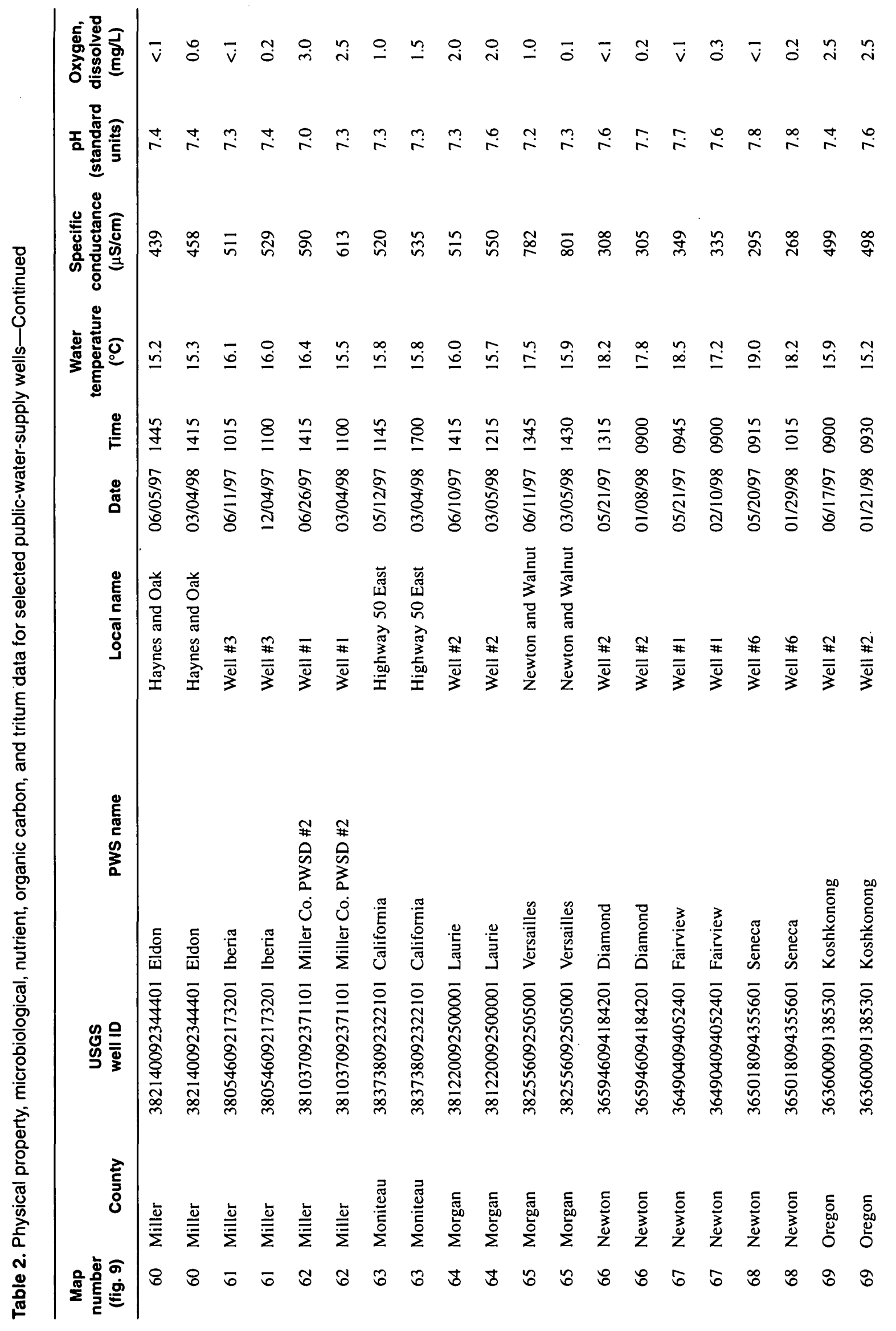

Physical Property, Microbioogical, Nutrient, Organic Carbon, and Tritum Data for Selected Public-Water-Supply-Wells 


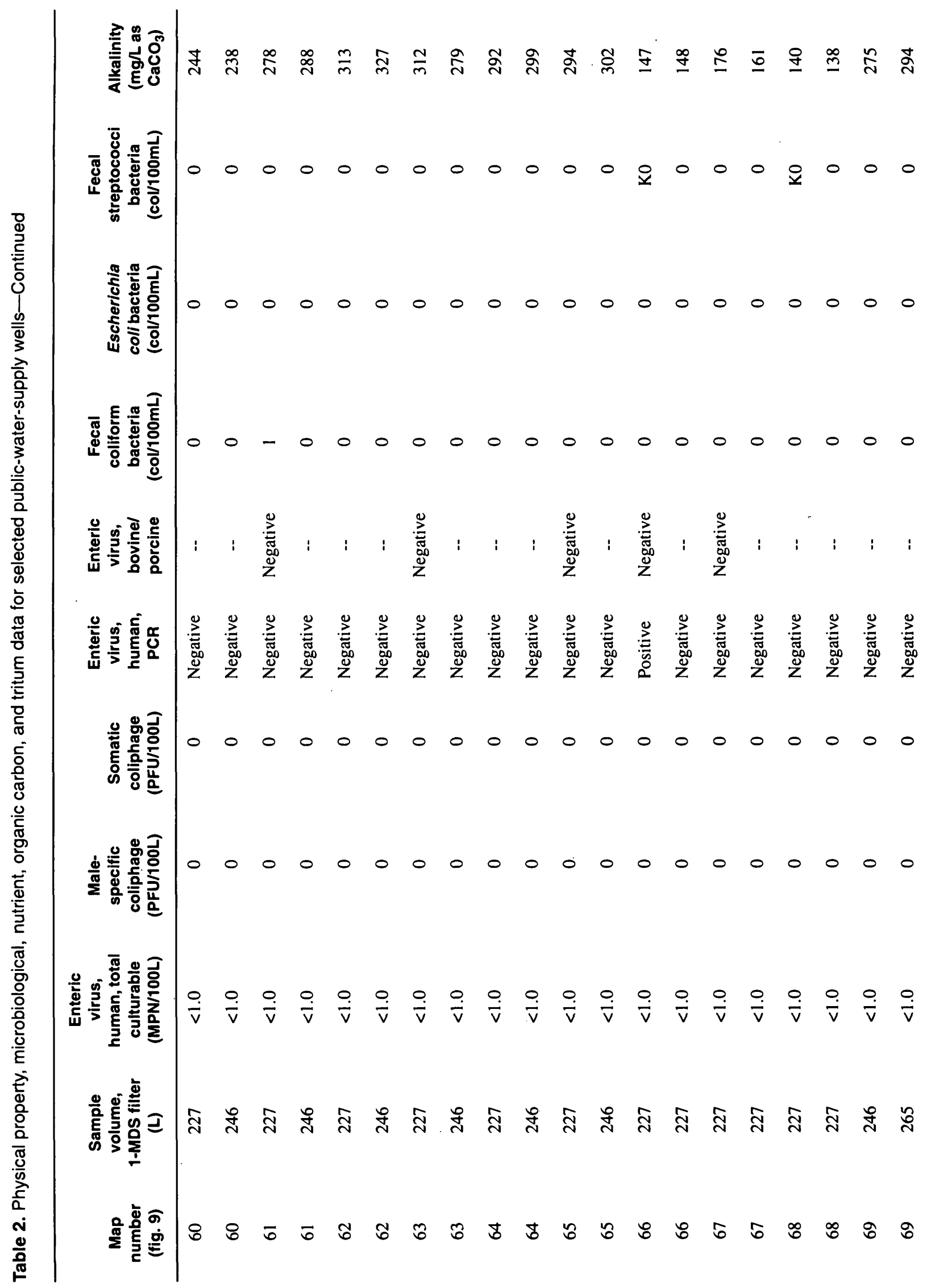




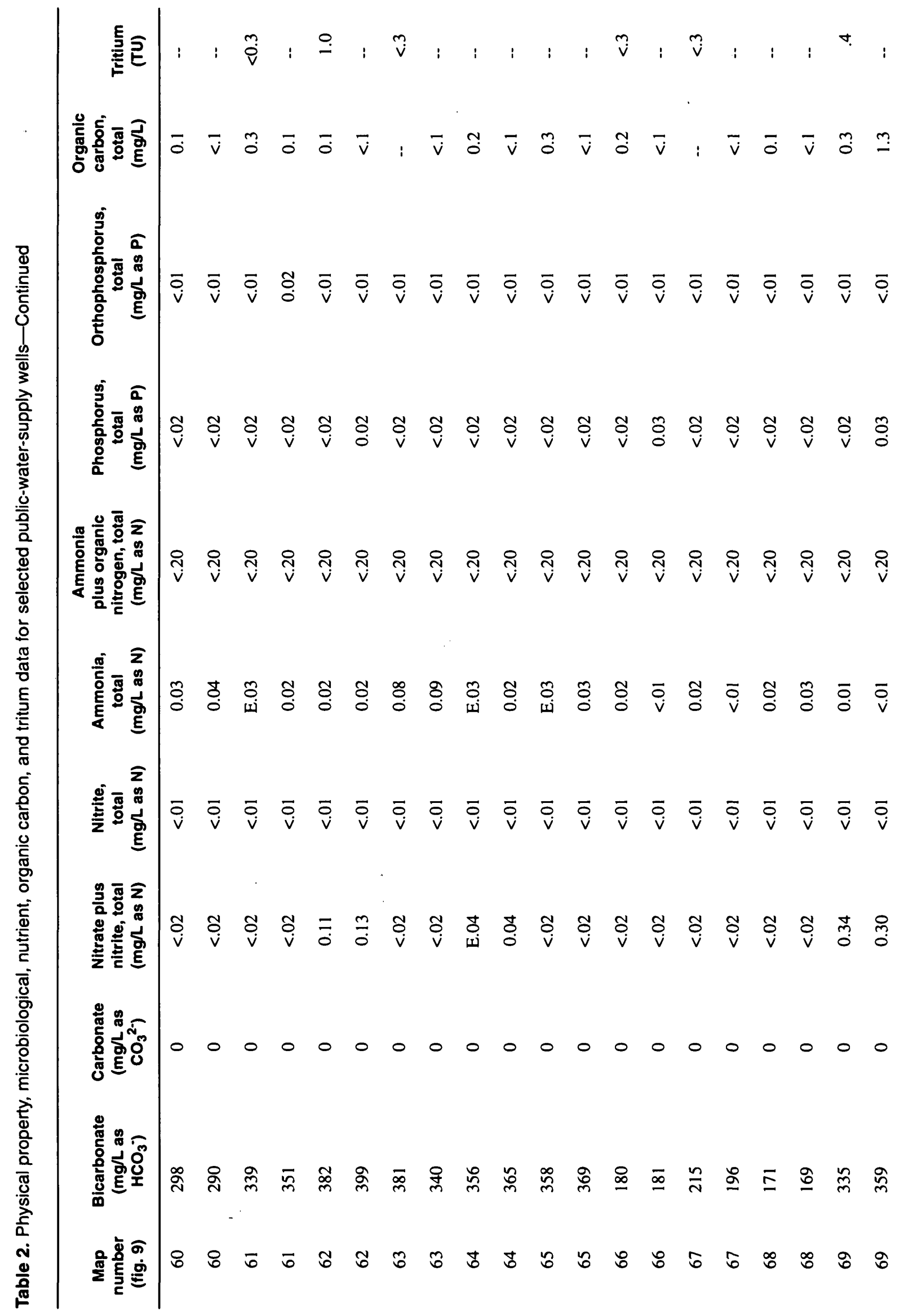

Physical Property, Microbloogical, Nutrient, Organic Carbon, and Tritum Data for Selected Public-Water-Supply-Wells 


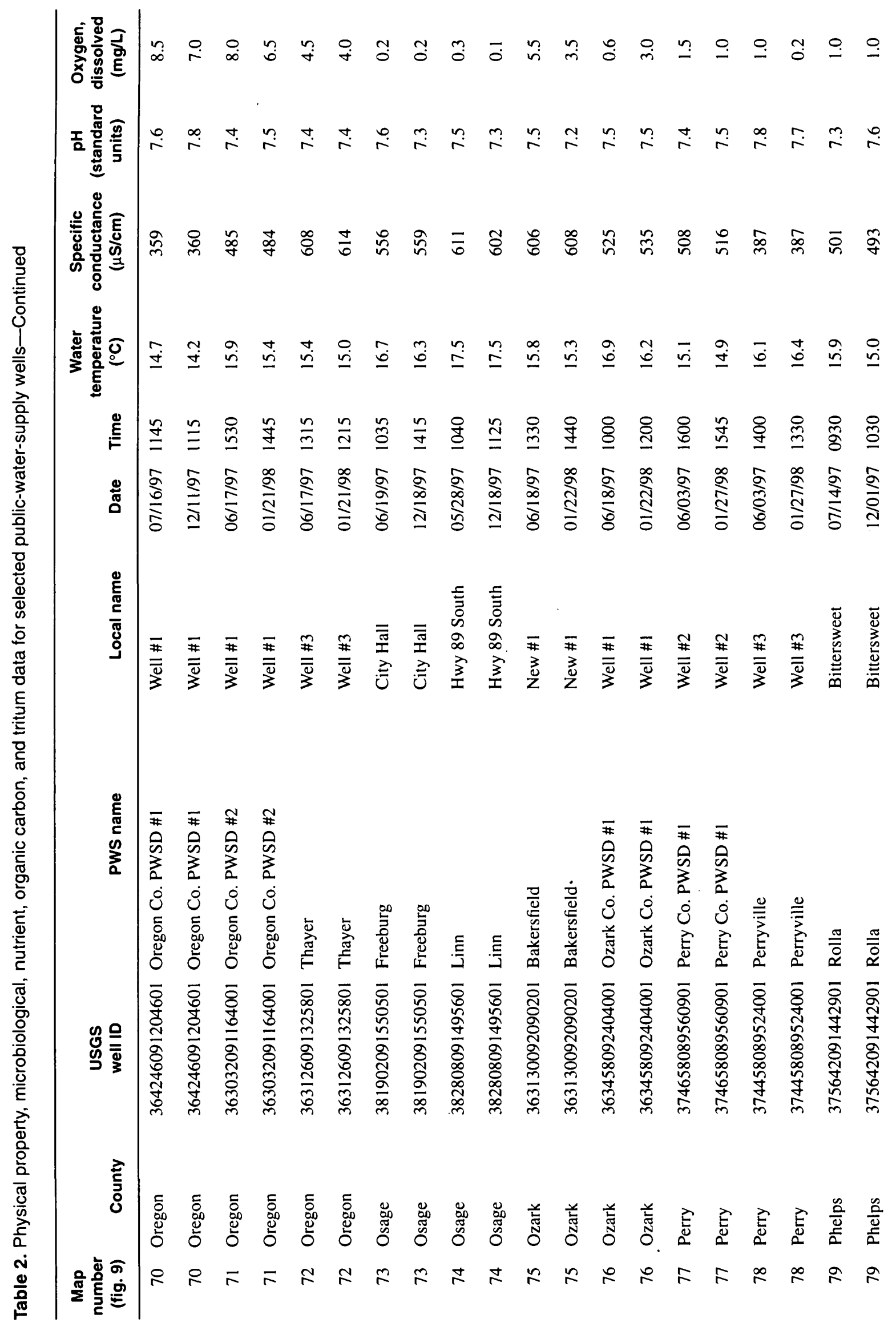




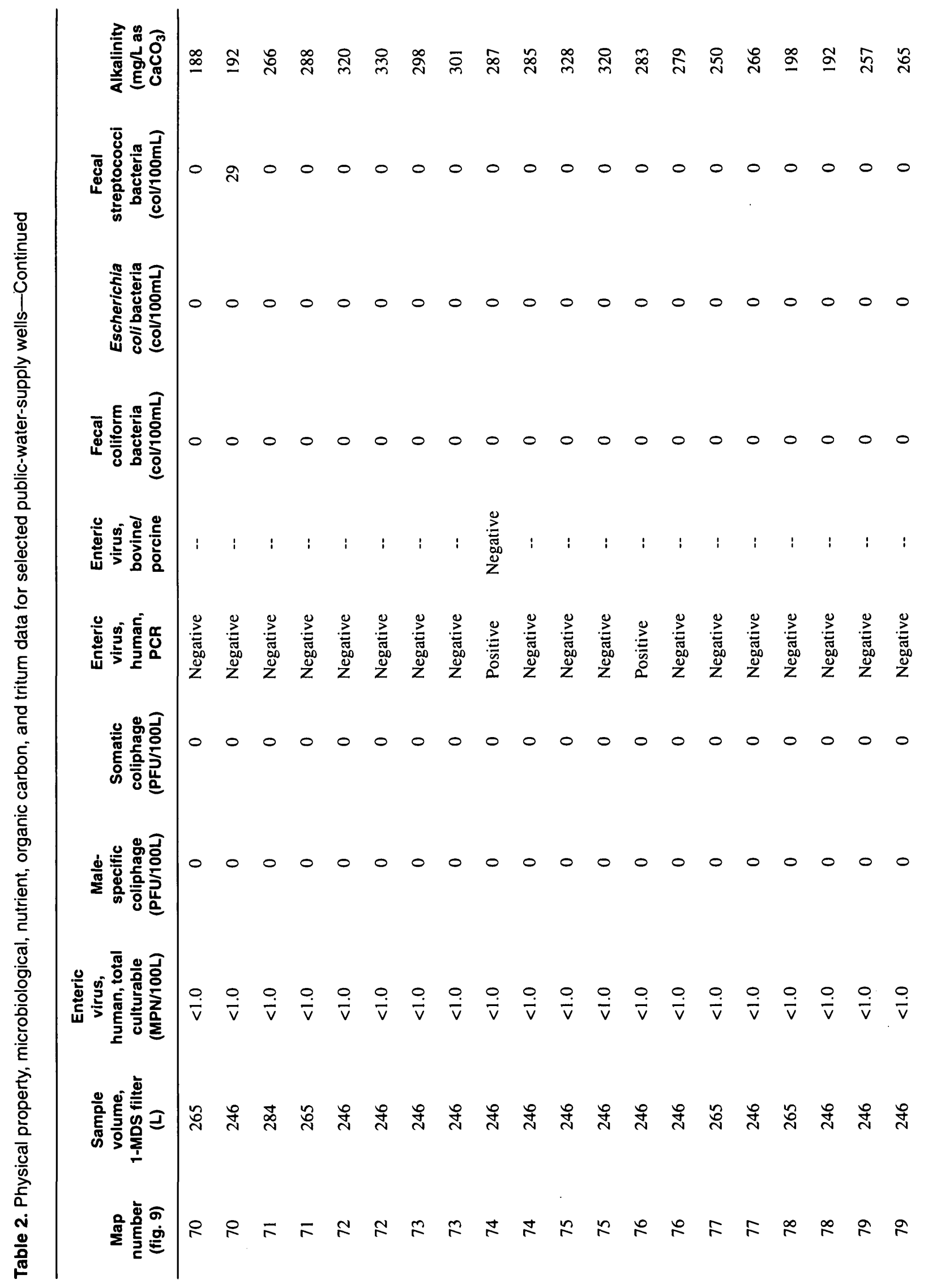




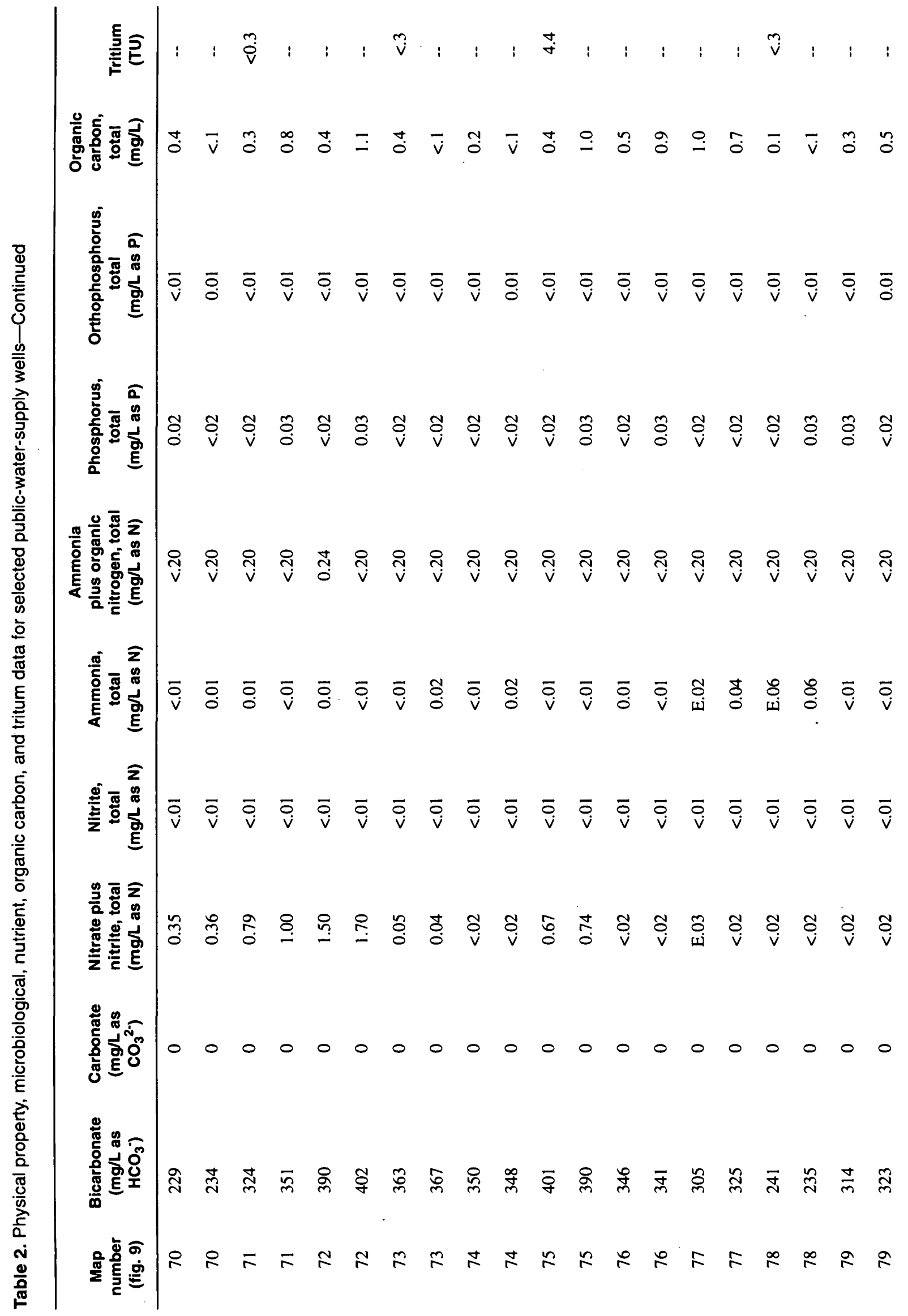




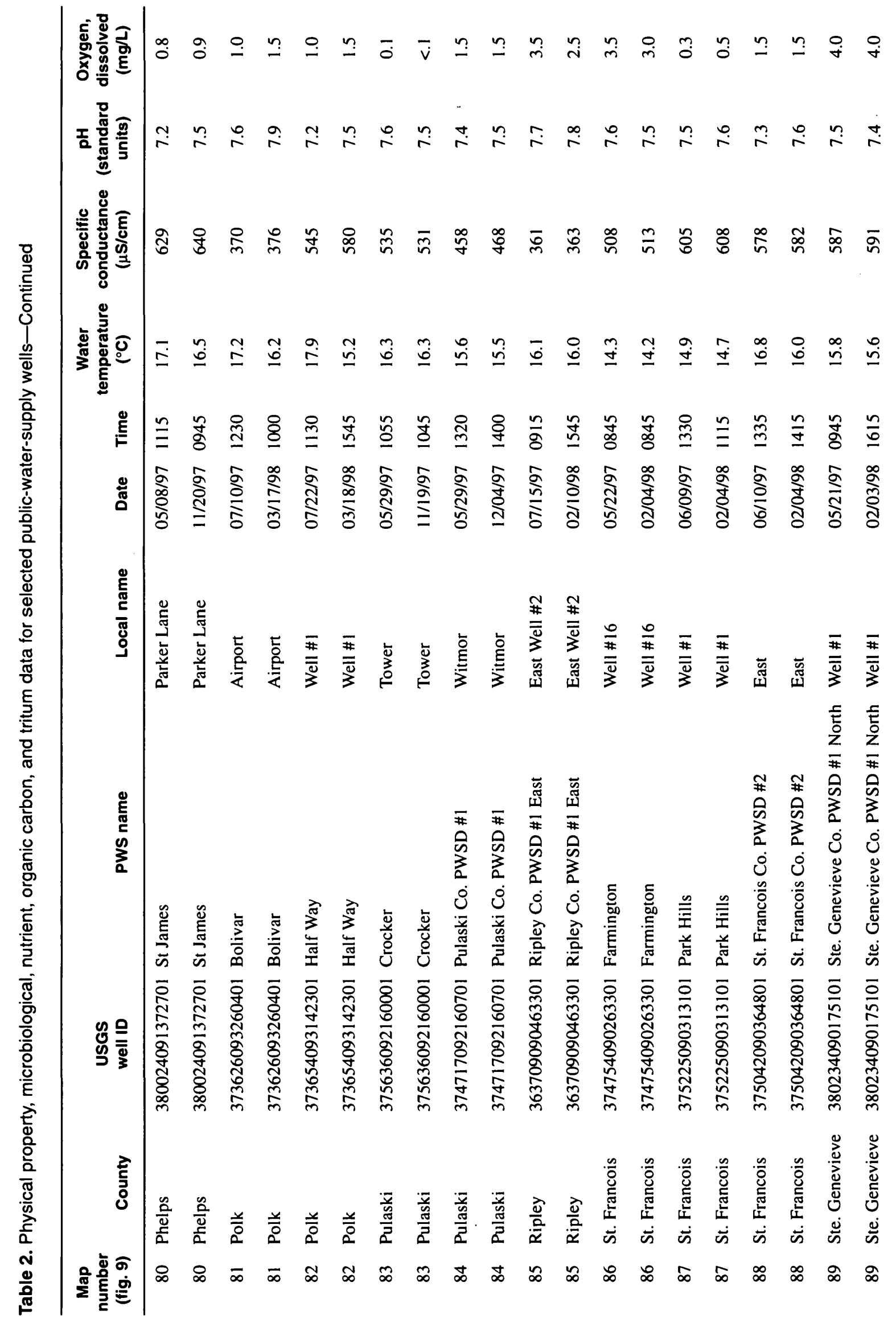

Physical Property, Microbloogical, Nutrient, Organic Carbon, and Tritum Data for Selected Public-Water-Supply-Wells 


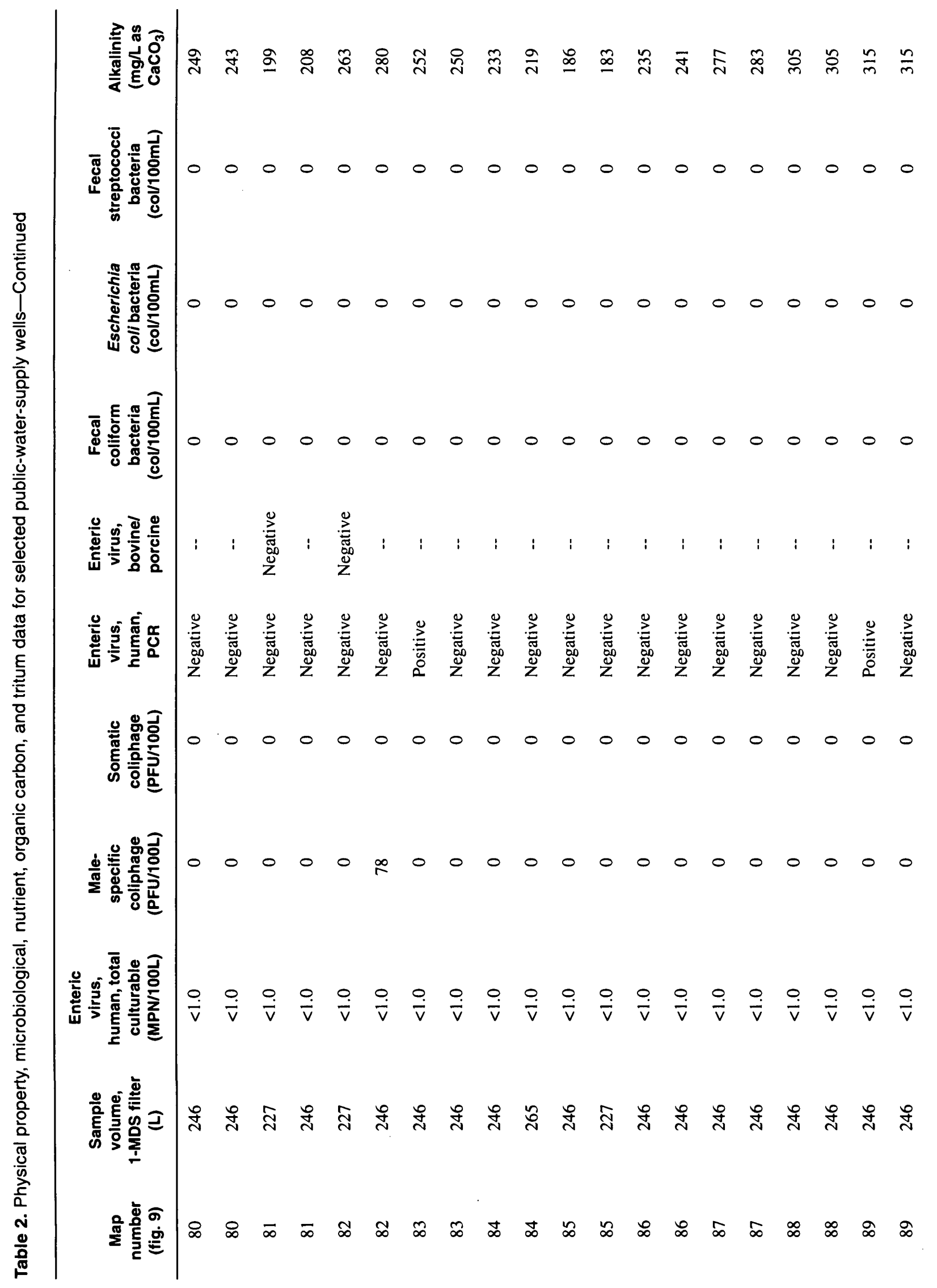




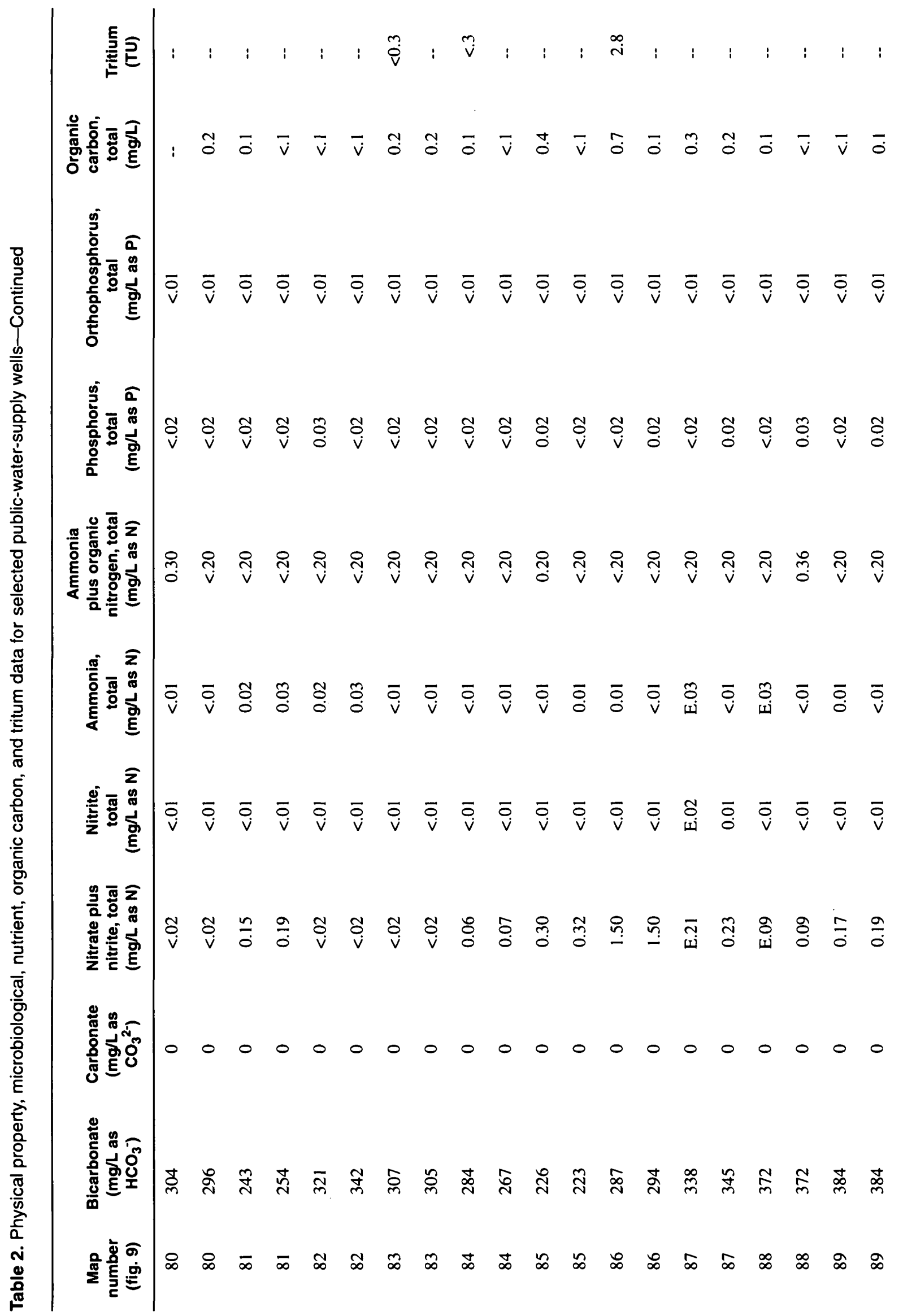




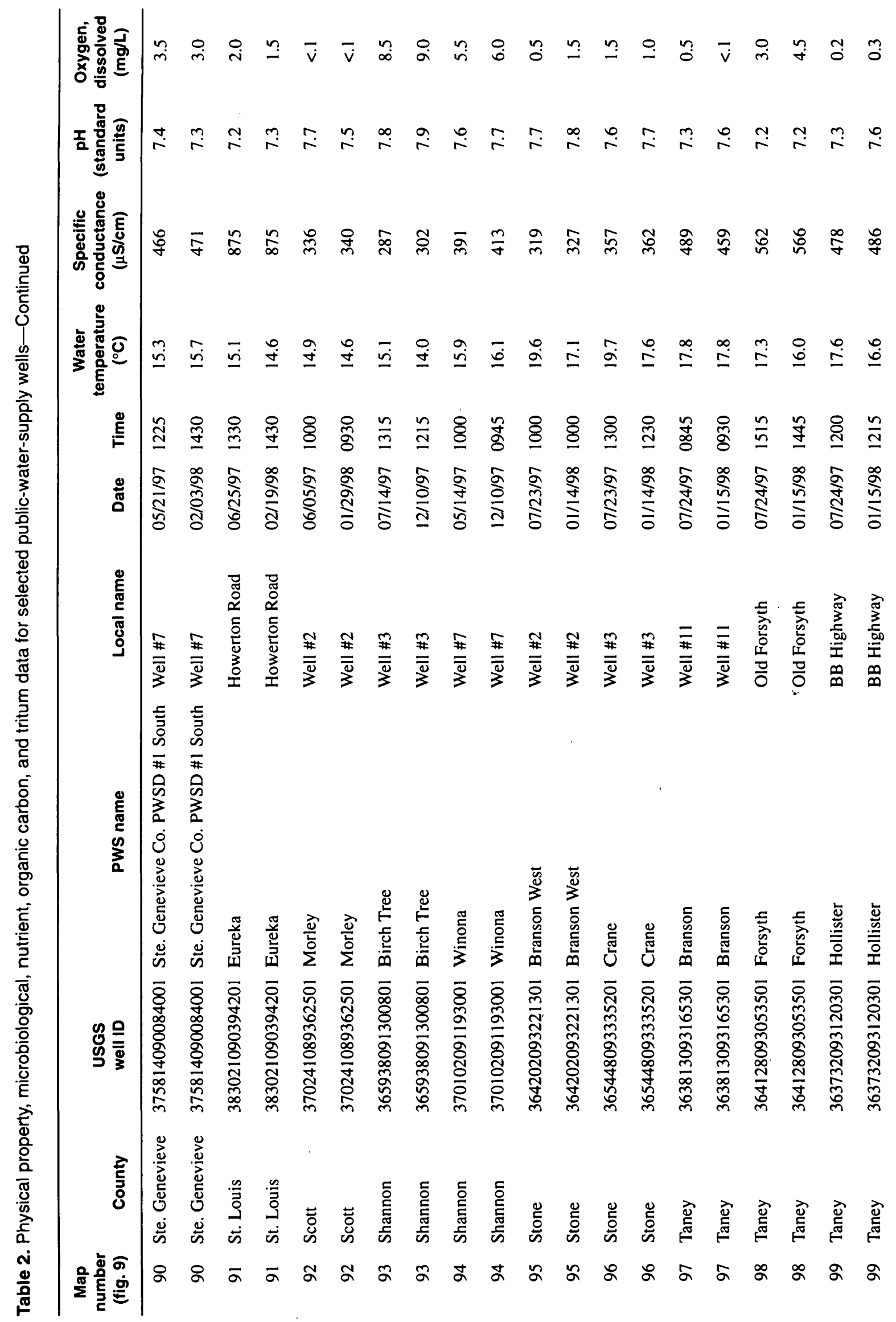




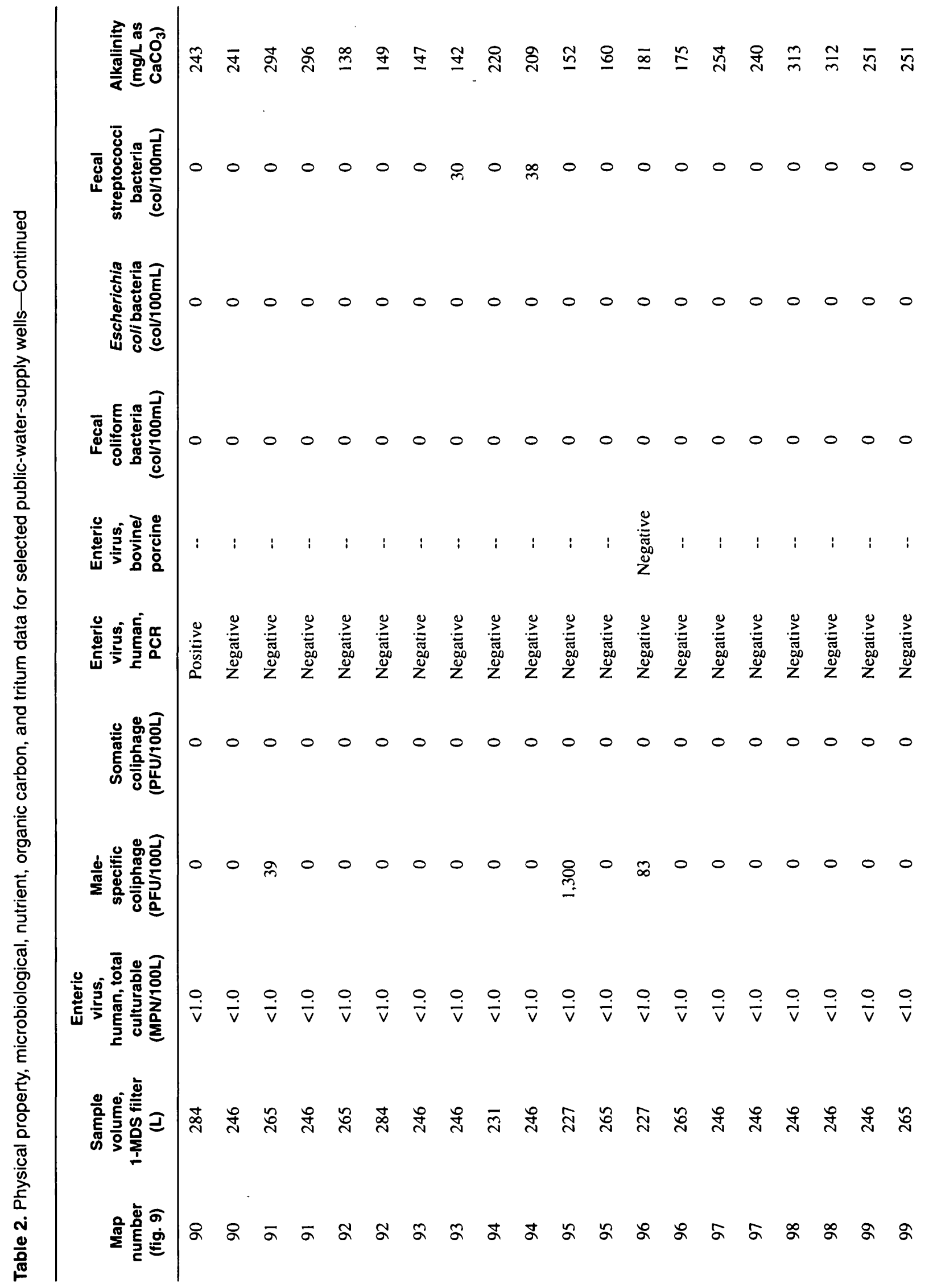




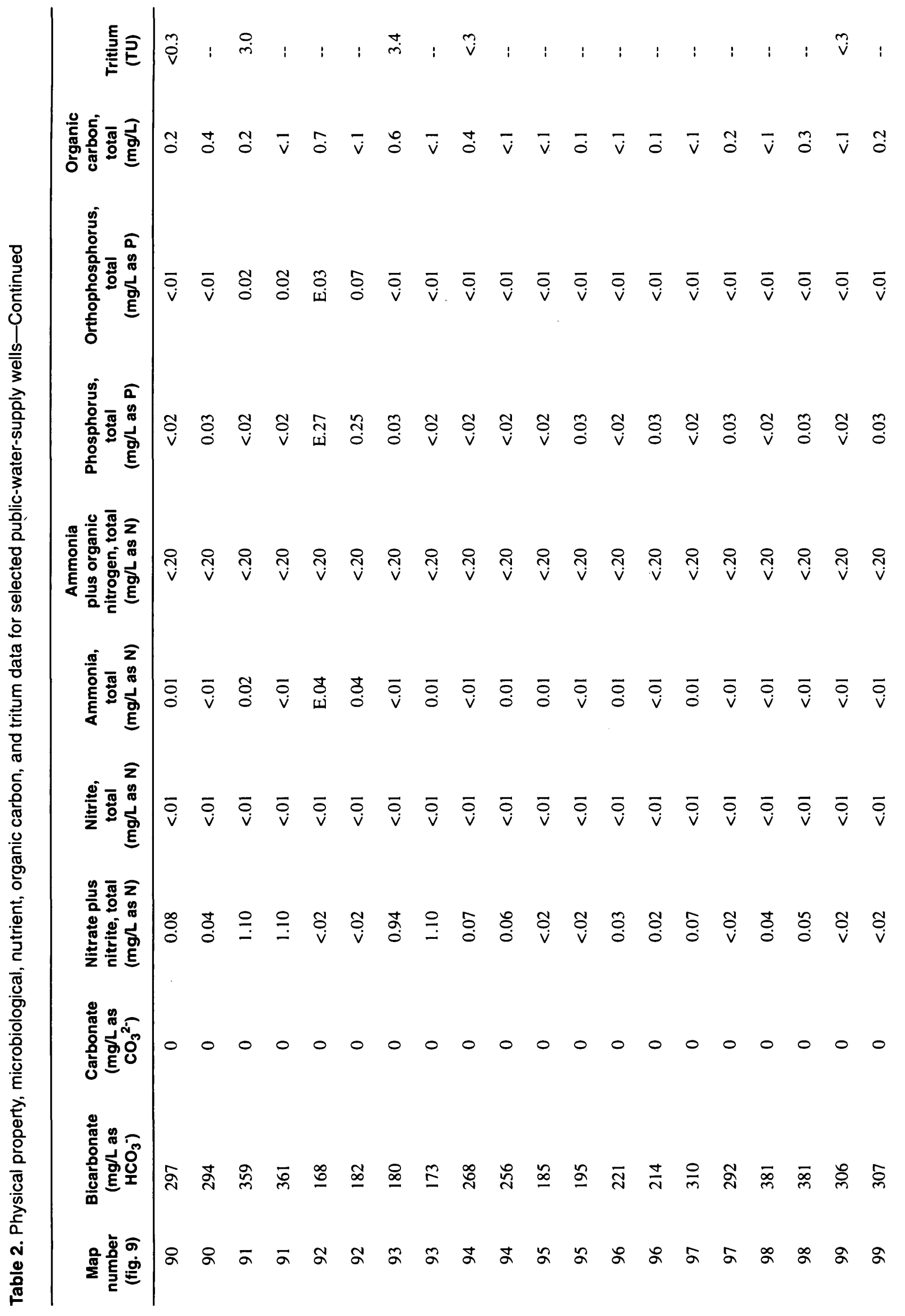




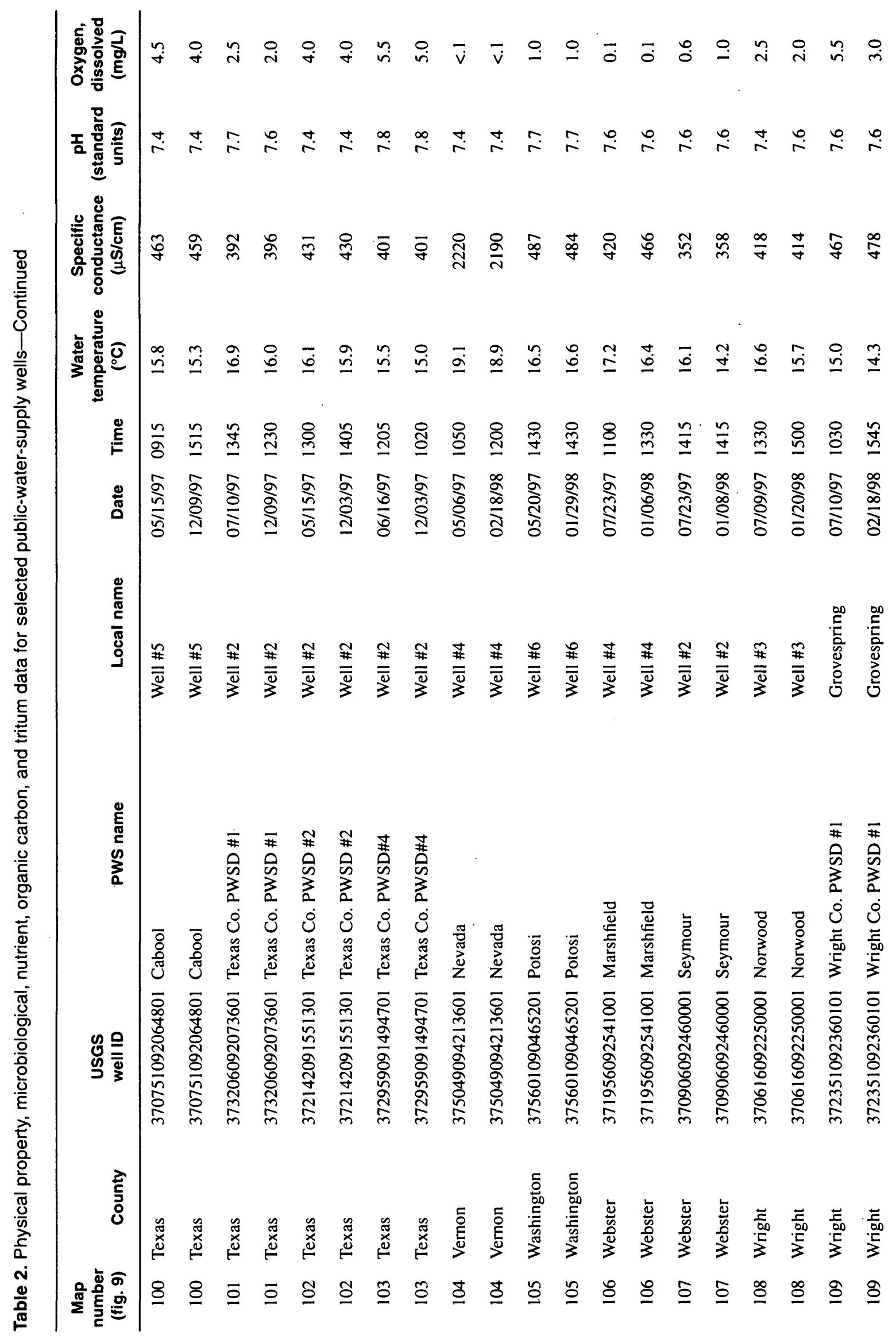




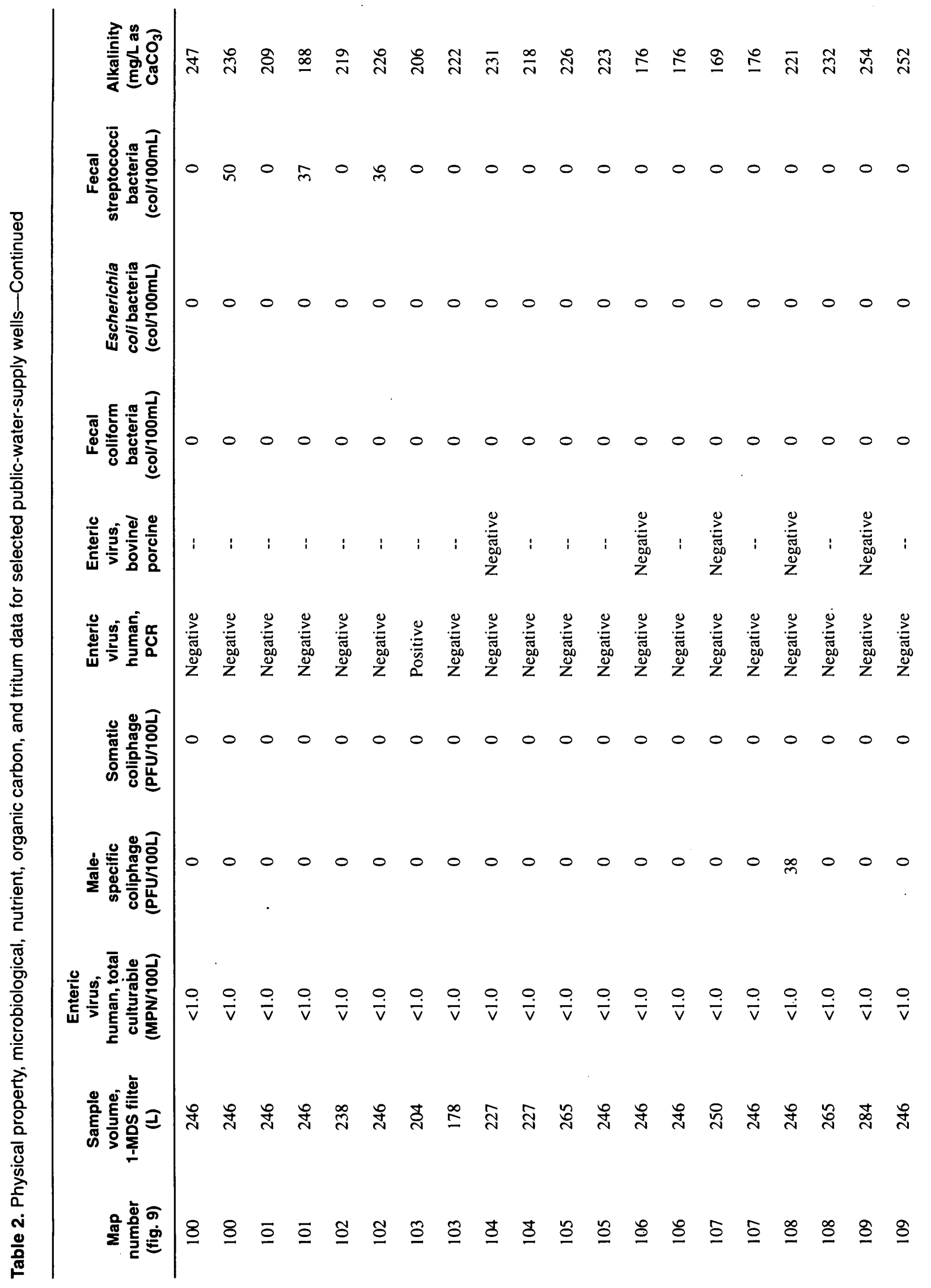




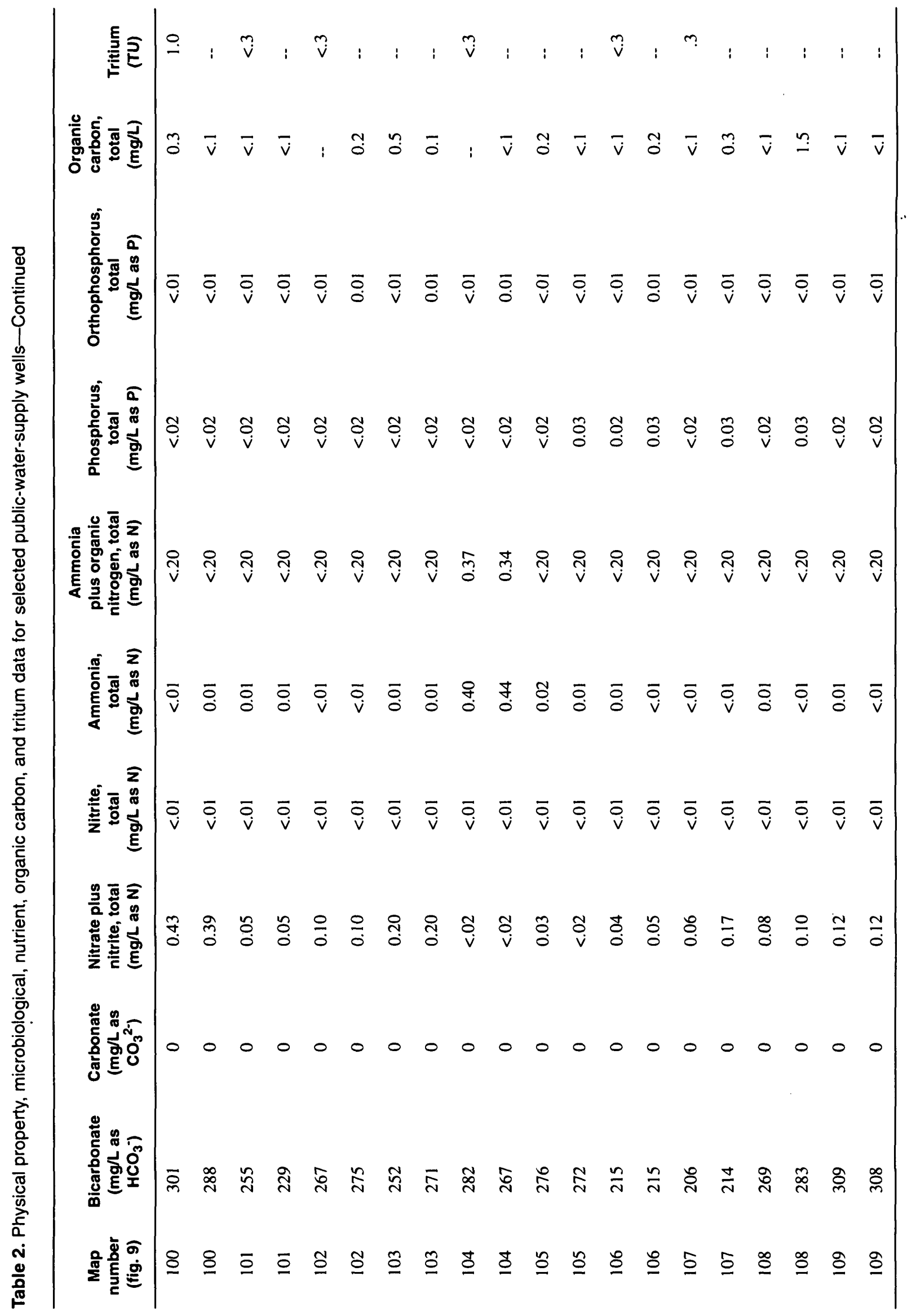

Physical Property, Microbioogical, Nutrient, Organic Carbon, and Tritum Data for Selected Public-Water-Supply-Wells 


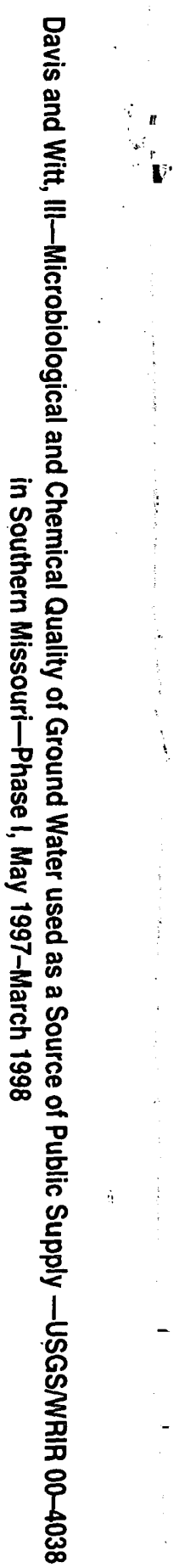

Printed on recycied paper 